\title{
13. COCCOLITH BIOSTRATIGRAPHY OF THE NORTH ATLANTIC OCEAN, DEEP SEA DRILLING PROJECT LEG 941
}

\author{
Toshiaki Takayama, Department of Geology, Kanazawa University, Japan \\ and \\ Tokiyuki Sato, Technical Research Center, Teikoku Oil Co., Tokyo, Japan ${ }^{2}$
}

\begin{abstract}
We studied calcareous nannofossil assemblages in 860 samples recovered during DSDP Leg 94 in order to estimate the age of the sediments at six sites in the North Atlantic Ocean. Twenty-one biohorizons are recognized in the Neogene and Quaternary sequences deposited at middle and high latitudes. Correlation of these biohorizons with the magnetostratigraphy established for the same cores indicates that three of these biohorizons, the Last Appearance Datum (LAD) and First Appearance Datum (FAD) of Helicosphaera inversa and the LAD of Sphenolithus abies, are ecologically controlled and cannot be used as stratigraphic indicators. In the floral reference list one new species (Coccolithus streckeri) is described.
\end{abstract}

\section{INTRODUCTION}

Leg 94 of the IPOD phase of the Deep Sea Drilling Project began at Norfolk, Virginia on 23 June, 1983 and ended at St. Johns, Newfoundland on 17 August. During this leg, 22 holes were drilled at 6 sites on a roughly south-southwest to north-northeast transect in the North Atlantic from 37 to $53^{\circ} \mathrm{N}$ (Fig. 1, Table 1). Cenozoic sediments were recovered by continuous hydraulic piston coring (HPC) and use of the extended core barrel (XCB). Thick sequences of carbonate ooze and mud were penetrated, and abundant calcareous nannofossils were found throughout the cores at all sites.

The main purpose of this report is to describe the calcareous nannofossil assemblages and their stratigraphic changes, to discuss the basis for biostratigraphic age assignments, and to correlate nannofossil biohorizons defined by the first and last occurrences of selected species with the levels of magnetic reversals.

\section{METHODS}

On Leg 94 the hydraulic piston corer was used to recover long, undisturbed, continuous sections. At depths below HPC refusal, relatively undisturbed sediment sequences were obtained with the extended core barrel; therefore these cores are well-suited for detailed biostratigraphic sampling.

All samples were taken on board the Glomar Challenger. The sample spacing in critical intervals is sufficiently close (usually 1 sample/ $1.5 \mathrm{~m}$ ) to determine stratigraphic positions of first and last occurrences of selected species with reasonable accuracy.

The outermost portion of each sample was removed to avoid floral contamination caused by drag of the sediment against the core liner. A total of 860 samples was processed and examined employing commonly accepted techniques as described by Stradner and Papp (1961). Approximately $5 \mathrm{mg}$ of the samples was placed in a beaker and about $20 \mathrm{ml}$ of water was added. This beaker was placed in an ultrasonic cleaner (BRANSONIC 12) at a moderate vibration setting. After $5 \mathrm{~s}$,

\footnotetext{
${ }^{1}$ Ruddiman, W. F., Kidd, R. B., Thomas, E., et al., Init. Repts. DSDP, 94: Washington (U.S. Govt. Printing Office).

2 Addresses: (Takayama) Dept. of Geology, College of Liberal Arts, Kanazawa University, Kanazawa, 920 Japan; (Sato) Technical Research Center, Teikoku Oil Co., Ltd., Kitakarasuyama, Setagaya-ku, Tokyo, 157 Japan.
}

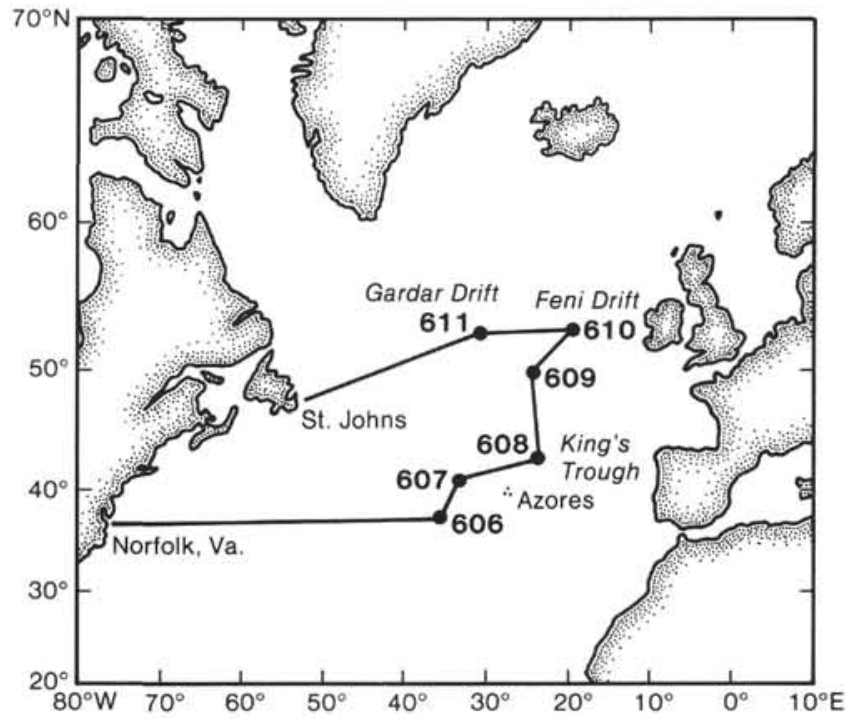

Figure 1. Location map of Sites 606 through 611, Leg 94.

the beaker was removed from the ultrasonic cleaner; after the heavier particles had settled, about $1 \mathrm{~cm}^{3}$ was withdrawn from the upper layer of the suspension with a pipette and placed on a square microscopic cover glass $(18 \mathrm{~mm} \times 18 \mathrm{~mm})$ and carefully allowed to dry on an electric hot plate set at approximately 40 to $50^{\circ} \mathrm{C}$. The mounting reagent "Eukitt" was then spread over it and the cover glass was pressed on a glass slide.

The slide was examined under an Olympus Binocular Polarizing Microscope (BHA-P) at a magnification of $1500 \times$, with an oil-immersion objective lens. Several thousand coccolith and discoaster specimens were identified. In addition, 200 specimens were counted at random and listed in order to determine the relative frequencies of occurrence of the species and their stratigraphic changes.

The relative frequencies were designated by using one of the following codes: $\mathrm{A}=$ abundant (more than $32 \%$ of the species in total assemblage), $\mathrm{C}=$ common ( $32-8 \%$ of the species in total assemblage), $\mathrm{F}=$ few $(8-2 \%$ of the species in total assemblage), $\mathrm{R}=$ rare (less than $2 \%$ of the species in total assemblage), and $+=$ present (found but not counted).

The overall preservation of nannofossil assemblages was recorded using one of three letter designations (Steinmetz, 1979): $\mathrm{G}=$ good preservation-fossils lack evidence of dissolution or overgrowth; $\mathbf{M}=$ 
Table 1. Locations of Leg 94 sites.

\begin{tabular}{|c|c|c|c|}
\hline Hole & Latitude & Longitude & $\begin{array}{c}\text { Water } \\
\text { depth } \\
\text { (m) }\end{array}$ \\
\hline 606 & $37^{\circ} 20.32^{\prime} \mathrm{N}$ & $35^{\circ} 29.99^{\prime} \mathrm{W}$ & 3007 \\
\hline $606 \mathrm{~A}$ & $37^{\circ} 20.29^{\prime} \mathrm{N}$ & $35^{\circ} 30.02^{\prime} \mathrm{W}$ & 3007 \\
\hline 607 & $41^{\circ} 00.07^{\prime} \mathrm{N}$ & $32^{\circ} 57.44^{\prime} \mathrm{W}$ & 3427 \\
\hline $607 \mathrm{~A}$ & $41^{\circ} 00.07^{\prime} \mathrm{N}$ & $32^{\circ} 57.44^{\prime} \mathrm{W}$ & 3427 \\
\hline 608 & $42^{\circ} 50.21^{\prime} \mathrm{N}$ & $23^{\circ} 05.25^{\prime} \mathrm{W}$ & 3526 \\
\hline $608 \mathrm{~A}$ & $42^{\circ} 50.21^{\prime} \mathrm{N}$ & $23^{\circ} 05.25^{\prime} \mathrm{W}$ & 3526 \\
\hline 609 & $49^{\circ} 52.67^{\prime} \mathrm{N}$ & $24^{\circ} 14.29^{\prime} \mathrm{W}$ & 3884 \\
\hline $609 \mathrm{~A}$ & $49^{\circ} 52.67^{\prime} \mathrm{N}$ & $24^{\circ} 14.29^{\prime} \mathrm{W}$ & 3883 \\
\hline $609 \mathrm{~B}$ & $49^{\circ} 52.67^{\prime} \mathrm{N}$ & $24^{\circ} 14.29^{\prime} \mathrm{W}$ & 3883 \\
\hline $609 \mathrm{C}$ & $49^{\circ} 52.67^{\prime} \mathrm{N}$ & $24^{\circ} 14.29^{\prime} \mathrm{W}$ & 3883 \\
\hline 610 & $53^{\circ} 13.30^{\prime} \mathrm{N}$ & $18^{\circ} 53.21^{\prime} \mathrm{W}$ & 2417 \\
\hline $610 \mathrm{~A}$ & $53^{\circ} 13.30^{\prime} \mathrm{N}$ & $18^{\circ} 53.21^{\prime} \mathrm{W}$ & 2417 \\
\hline $610 \mathrm{~B}$ & $53^{\circ} 13.30^{\prime} \mathrm{N}$ & $18^{\circ} 53.21^{\prime} \mathrm{W}$ & 2417 \\
\hline $610 \mathrm{C}$ & $53^{\circ} 13.30^{\prime} \mathrm{N}$ & $18^{\circ} 53.21^{\prime} \mathrm{W}$ & 2417 \\
\hline $610 \mathrm{D}$ & $53^{\circ} 13.47^{\prime} \mathrm{N}$ & $18^{\circ} 53.69^{\prime} \mathrm{W}$ & 2445 \\
\hline $610 \mathrm{E}$ & $53^{\circ} 13.47^{\prime} \mathrm{N}$ & $18^{\circ} 53.69^{\prime} \mathrm{W}$ & 2445 \\
\hline 611 & $52^{\circ} 50.47^{\prime} \mathrm{N}$ & $30^{\circ} 18.58^{\prime} \mathrm{W}$ & 3203 \\
\hline $611 \mathrm{~A}$ & $52^{\circ} 50.47^{\prime} \mathrm{N}$ & $30^{\circ} 18.58^{\prime} \mathrm{W}$ & 3201 \\
\hline $611 B$ & $52^{\circ} 50.15^{\prime} \mathrm{N}$ & $30^{\circ} 19.10^{\prime} \mathrm{W}$ & 3228 \\
\hline $611 C$ & $52^{\circ} 50.15^{\prime} \mathrm{N}$ & $30^{\circ} 19.10^{\prime} \mathrm{W}$ & 3230 \\
\hline 611D & $52^{\circ} 50.47^{\prime} \mathrm{N}$ & $30^{\circ} 18.58^{\prime} \mathrm{W}$ & 3195 \\
\hline $611 \mathrm{E}$ & $52^{\circ} 50.47^{\prime} \mathrm{N}$ & $30^{\circ} 18.58^{\prime} \mathrm{W}$ & 3195 \\
\hline
\end{tabular}

moderately good preservation-the majority of the specimens is slightly etched (fine structures are missing, but no diagnostic changes of form are evident in light microscopy; all taxa may be easily identified); and $\mathrm{P}=$ poor preservation-the majority of the specimens is deeply etched (identity of many centerless and fragmental specimens is questionable).

Sample material used during the present investigation is permanently in the Micropaleontology Collection of the Department of Geology, College of Liberal Arts, Kanazawa University. Slides are located at Teikoku Oil Co., Ltd., Tokyo and College of Liberal Arts, Kanazawa University.

\section{NANNOFOSSIL ZONATION}

Cenozoic calcareous nannofossil zonation schemes, based primarily on land or epicontinental sections, have been established by numerous investigators. Among them, the "Standard Calcareous Nannofossil Zonation" established by Martini (1971) is most applicable and widely used. He summarized the Cenozoic nannofossil zonation, and gave ranges of important species and correlation of his zones with planktonic foraminiferal and radiolarian zones. Another comprehensive zonation was proposed by Bukry $(1973,1975)$ for low-latitude deep-sea sections. Subsequently Okada and Bukry (1980) introduced code numbers to this zonation, and this scheme proved to be a more practical approach to deep-sea calcareous nannofossil biostratigraphy.

Calcareous nannoplankton attain their maximum diversity in tropical areas, as do planktonic foraminifers. Many tropical forms used as index fossils are not found at higher latitudes, and the number of usable coccolith guide species decreases with increasing latitude; thus zonal intervals must be expanded poleward, with consequent loss of biostratigraphic resolution. This created a serious problem in interpreting the Neogene calcareous nannofossil biostratigraphy of Leg 94 samples.

The zonal scheme established by Martini (1971) is employed throughout this chapter to make zonal and geological age assignments of the samples (Table 2). This zonation, however, was not applicable for the lower Pli- ocene and most of the Miocene sedimentary sequences recovered during Leg 94 because of the absence of many important index fossils used for zonation at low latitudes (e.g., ceratoliths and asteroliths). Only those stratigraphic intervals characterized by the presence of relevant species are discussed; see Table 2 for overall zonation of Leg 94 samples.

\section{SUMMARY OF NANNOFOSSIL BIOSTRATIGRAPHY}

\section{Site 606}

Site 606 is located on the upper western flank of the Mid-Atlantic Ridge and consists of two holes. Quaternary and Pliocene calcareous nannofossil assemblages were recovered from this site. Preservation is good in the Pleistocene and upper Pliocene and moderate in the lower Pliocene, because of overgrowth of calcite on many specimens.

\section{Hole 606 (Table 3)}

Samples 1-2, 47-48 cm, 1,CC, and 2-2, 47-48 cm are assigned to the Emiliania huxleyi Zone (NN21). Emiliania huxleyi, Calcidiscus leptoporus, and gephyrocapsids are dominant. Coccolithus pelagicus, Oolithotus antillarum, Rhabdosphaera clavigera, and Scapholithus fossilis are frequent. In this zone, Helicosphaera inversa occurs in Sample 2-2, 47-48 cm. Because of the absence of Emiliania huxleyi and Pseudoemiliania lacunosa, Samples 2-3, 47-48 $\mathrm{cm}$ through $2-5,47-48 \mathrm{~cm}$ are assigned to Zone NN20 (Gephyrocapsa oceanica Zone). The presence of Pseudoemiliania lacunosa in Samples 2-6, 47-48 $\mathrm{cm}$ through 7-6, 47-48 $\mathrm{cm}$ indicates an early Pleistocene age (NN19, Pseudoemiliania lacunosa Zone). Helicosphaera sellii and Calcidiscus macintyrei occur consistently below Samples 5-4, 47-48 cm and 6-6, 47-48 cm, respectively, but Helicosphaera inversa and Gephyrocapsa parallela occur in the interval above Samples 2, CC and 4-3, 47-48 cm, respectively. The top of the acme of Reticulofenestra-like species (Reticulofenestra $\mathrm{sp.} \mathrm{A)} \mathrm{is}$ in Sample 3,CC. Comparatively large $(>6 \mu \mathrm{m})$ specimens of Gephyrocapsa are limited to the interval from Sample 5-1, 47-48 cm down to Sample 6-1, 47-48 cm. Gephyrocapsa oceanica occurs only above Sample 6-5, $47-48 \mathrm{~cm}$, and Calcidiscus macintyrei is present below Sample 6-6, 47-48 cm.

The Pliocene/Pleistocene boundary is marked sharply-between Samples 7-6, 47-48 cm and 7,CC; below this level Discoaster brouweri occurs continually. Samples 7,CC through 9-2, $47-48 \mathrm{~cm}$ contain Calcidiscus leptoporus, Emiliania ovata, and Pseudoemiliania lacunosa, together with Discoaster brouweri and D. triradiatus; therefore these are assigned to latest Pliocene Zone NN18 (Discoaster brouweri Zone). Lower in the section, the assemblage is characterized by the occurrences of various discoasters. The presence of Discoaster brouwe$r i$ and $D$. pentaradiatus places Sample $9-4,47-48 \mathrm{~cm}$ in Zone NN17 (Discoaster pentaradiatus Zone). Samples $9, \mathrm{CC}$ through $14, \mathrm{CC}$ contain comparatively diversified discoaster species such as $D$. asymmetricus, $D$. brouwe$r i, D$. intercalaris, $D$. pentaradiatus, and $D$. surculus; 
Reticulofenestra pseudoumbilica also occurs sporadically. This last species, however, is not abundant, and therefore these samples belong in late Pliocene Zone NN16 (Discoaster surculus Zone). In this zone, Discoaster tamalis is found below Sample 10,CC only. The top of the acme of Reticulofenestra pseudoumbilica is recognized in Sample 15-2, 47-48 cm, so all lower samples are assigned to early Pliocene Zone NN15 (Reticulofenestra pseudoumbilica Zone). Sphenolithus abies occurs in Sample $15-4,47-48 \mathrm{~cm}$, slightly below the top of Zone NN15 (Reticulofenestra pseudoumbilica Zone). In this zone some Amaurolithus specimens are recognized.

\section{Hole 606A (Table 4)}

Nannofossil assemblages in Hole 606 A are similar to those observed in Hole 606. Sample 1,CC is assigned to the late Pleistocene to Holocene Emiliania huxleyi Zone (NN21). The presence of Pseudoemiliania lacunosa in Samples 2,CC to 6,CC indicates an early Pleistocene age (NN19, Pseudoemiliania lacunosa Zone) for these samples.

The Pliocene/Pleistocene boundary is placed between Samples 6,CC and 7,CC. Samples 7,CC is assigned to Zone NN18 (Discoaster brouweri Zone). Discoaster brouweri and $D$. pentaradiatus co-occur in Sample $8, C C$, which is placed in Zone NN17 (Discoaster pentaradiatus Zone). Below this, discoasters gradually increase in number of species and in number of specimens. Reticulofenestra pseudoumbilica is present. This species, however, increases in Sample 14,CC. Specimens of $R$. pseudoumbilica above the acme of this species are most probably reworked. Consequently, the boundary between the Discoaster surculus Zone (NN16) and the Reticulofenestra pseudoumbilica Zone (NN15) is tentatively placed between Samples 13,CC and 14,CC. Because Amaurolithus tricorniculatus occurs in Samples 19-2, 47-48 cm and $19, \mathrm{CC}$, the boundary between Zones NN15 (Reticulofenestra pseudoumbilica Zone) and NN14 (Discoaster asymmetricus Zone) is in the upper part of Core 19.

\section{Site 607}

Site 607 is less than $250 \mathrm{n}$. mi. north of Site 606 . Two holes, drilled on the upper middle western flank of the Mid-Atlantic Ridge, provided a largely overlapping and partly composite section down to the upper Miocene. Calcareous nannofossils are abundant throughout. The assemblages are characterized by good to moderate preservation and range from Quaternary to upper Miocene; species diversity is comparatively high.

\section{Hole 607 (Table 5)}

Samples 1-2, 47-48 cm through 9-6, 47-48 cm contain Pleistocene to Holocene assemblages such as Emiliania huxleyi, Pseudoemiliania lacunosa, Gephyrocapsa caribbeanica, G. oceanica, G. parallela, Helicosphaera inversa, $H$. sellii, Reticulofenestra sp. A, and Calcidiscus macintyrei. The uppermost four samples contain abundant Emiliania huxleyi and can be correlated with the late Pleistocene to Holocene Emiliania huxleyi Zone (NN21). Because Emiliania huxleyi and Pseudoemiliania lacunosa are absent in Samples 2-2, 47-48 cm to 2-5,
$47-48 \mathrm{~cm}$, they are assigned to the Pleistocene Gephyrocapsa oceanica Zone (NN20). The presence of abundant Pseudoemiliania lacunosa and the absence of discoasters place Samples 2-6, 47-48 cm down to 9-6, 47-48 cm in the Pseudoemiliania lacunosa Zone (NN19). Throughout these three Pleistocene to Holocene zones, Helicosphaera inversa is found in the interval between Samples $1, \mathrm{CC}$ and 3-2, 47-48 cm. Peculiar Reticulofenestra (Reticulofenestra sp. A) dominate below Sample 5-4, 47-48 $\mathrm{cm}$. Gephyrocapsa parallela occurs only above Sample $5-4,47-48 \mathrm{~cm}$. Gephyrocapsa oceanica and G. caribbeanica do not occur below Samples 8-4, 47-48 cm and 9$1,47-48 \mathrm{~cm}$, respectively. First occurrences of Calcidiscus macintyrei and Helicosphaera sellii are recognized in Samples 8-5, 47-48 cm and 6-6, 47-48 cm, respectively. Comparatively large specimens of Gephyrocapsa are found in Samples 6-4, 47-48 cm through 7-5, 47-48 cm.

The Pliocene/Pleistocene boundary is placed between Samples 9-6, 47-48 cm and 9,CC, below which Discoaster brouweri occurs almost continuously. Samples 9,CC through 11-2, 47-48 cm contain Discoaster brouweri together with a few specimens of $D$. triradiatus and, therefore, are assigned to the latest Pliocene Discoaster brouweri Zone (NN18). The occurrences of $D$. brouweri and D. pentaradiatus place Samples 11-4, 47-48 cm, 11,CC, and 12-2, 47-48 cm in the Discoaster pentaradiatus Zone (NN17). Below this level, the assemblage is characterized by the occurrences of various discoasters. Although a few Reticulofenestra pseudoumbilica were observed, Samples $12-4,47-48 \mathrm{~cm}$ through $17, \mathrm{CC}$ are assigned to the late Pliocene Discoaster surculus Zone (NN16). Abundant occurrences of Reticulofenestra pseudoumbilica were first observed in Sample 18-2, 47-48 cm and, therefore, Samples $18-2,47-48 \mathrm{~cm}$ to $21-4,47-48 \mathrm{~cm}$ are all placed in the early Pliocene Reticulofenestra pseudoumbilica Zone (NN15). Sphenolithus abies also occurs commonly in Sample 18-2, 47-48 cm; therefore the extinction level of this species may coincide with the top of the acme of Reticulofenestra pseudoumbilica. The assemblages in Samples 21,CC through 25,CC are characterized by the occurrences of Amaurolithus tricorniculatus, A. primus, and A. delicatus. As the occurrences of Ceratolithus rugosus and Discoaster asymmetricus are rare and sporadic, these samples are placed tentatively in the Discoaster asymmetricus Zone (NN14) to the Amaurolithus tricorniculatus Zone (NN12). Below Sample 25,CC Discoaster quinqueramus, the important marker species of the late Miocene Discoaster quinqueramus Zone (NN11), is found together with Discoaster berggrenii. Although $D$. quinqueramus occurs only occasionally in small numbers and the central stem is not prominent, NN11 seems to extend from Sample 26-2, $47-48 \mathrm{~cm}$ on down to the bottom of this hole.

\section{Hole 607A (Table 6)}

Sample 1,CC can be correlated with the Emiliania huxleyi Zone (NN21), because of the abundant occurrence of Emiliania huxleyi. Based on the absence of $E$. huxleyi and Pseudoemiliania lacunosa, Sample 2,CC is assigned to the Gephyrocapsa oceanica Zone (NN20). Because of the presence of $P$. lacunos $a$ and the absence 
Table 2. Geologic age and nannoplankton zone assignment of Leg 94 samples.

\begin{tabular}{|c|c|c|c|c|c|c|c|c|c|c|c|c|}
\hline \multicolumn{2}{|c|}{ Age } & Zone & 606 & $606 \mathrm{~A}$ & 607 & $607 \mathrm{~A}$ & 608 & $608 \mathrm{~A}$ & 609 & $609 \mathrm{~A}$ & $609 \mathrm{~B}$ & $609 \mathrm{C}$ \\
\hline \multirow{3}{*}{\multicolumn{2}{|c|}{ Quaternary }} & NN21 & $1-1$ to $2-2$ & I.CC & $1-2$ 10 2.1 & 1.CC & 1.2 to $1 .-4$ & $1, \mathrm{CC}$ & $1-2$ to 2.2 & & $1, \mathrm{CC}$ to $2, \mathrm{CC}$ & \\
\hline & & NN20 & 2.3 to 2.5 & & 2.2 to 2.5 & $2 . \mathrm{CC}$ & $1-5$ to $2-2$ & & $2, \mathrm{CC}$ to 3.4 & & $3, \mathrm{CC}$ & \\
\hline & & NN19 & 2.6107 .6 & $2, \mathrm{CC}$ to $6 . \mathrm{CC}$ & 2.6 to 9.6 & $3 . \mathrm{CC}$ to $9 . \mathrm{CC}$ & $\begin{array}{cc}2.3 & 6-2 \\
10 & 10 \\
5-4 & 7, \mathrm{CC}\end{array}$ & $2, \mathrm{CC}$ to $5, \mathrm{CC}$ & $3, \mathrm{CC}$ to $15-2$ & $1, \mathrm{CC}$ to $2, \mathrm{CC}$ & $4, \mathrm{CC}$ to $15, \mathrm{CC}$ & 1.CC \\
\hline \multirow{7}{*}{ Pliocene } & \multirow{3}{*}{ late } & NN18 & $7, \mathrm{CC}$ to 9.2 & $7 . \mathrm{CC}$ & 9. $\mathrm{CC}$ to 11.2 & $10 . \mathrm{CC}$ to $11 . \mathrm{CC}$ & 5.5 to $5-6$ & $6 . \mathrm{CC}$ & 15.4 to $19, \mathrm{CC}$ & & $16, \mathrm{CC}$ to $17, \mathrm{CC}$ & $2, \mathrm{CC}$ to $4, \mathrm{CC}$ \\
\hline & & NN17 & 9.4 & $8 . \mathrm{CC}$ & $11-4$ to $12-2$ & $12, \mathrm{CC}$ & & & $20-1$ to 20.4 & & & S.CC \\
\hline & & NN16 & $9, \mathrm{CC}$ to $14, \mathrm{CC}$ & $9, \mathrm{CC}$ to $13, \mathrm{CC}$ & 12.4 to $17 . \mathrm{CC}$ & $13, \mathrm{CC}$ to $18, \mathrm{CC}$ & $\begin{array}{lc}\text { s.CC } & 8-2 \\
& 10 \\
12.4 \\
12.4\end{array}$ & $7, \mathrm{CC}$ to $12, \mathrm{CC}$ & $20, \mathrm{CC}$ to $26 . \mathrm{CC}$ & & $19, \mathrm{CC}$ to $27, \mathrm{CC}$ & $6, \mathrm{CC}$ to $7, \mathrm{CC}$ \\
\hline & \multirow{4}{*}{ early } & NN1S & 15.2 to $18, \mathrm{CC}$ & $14, \mathrm{CC}$ to $19-1$ & 18.2 to 21.4 & $19, \mathrm{CC}$ to $20, \mathrm{CC}$ & $12, \mathrm{CC}$ to $13, \mathrm{CC}$ & $13, \mathrm{CC}$ to $14, \mathrm{CC}$ & $27.21027, \mathrm{CC}$ & & \multirow{2}{*}{$28, \mathrm{CC}$ to $32, \mathrm{CC}$} & \\
\hline & & $\mathrm{NN} / 4$ & & $19-2$ to $19, \mathrm{CC}$ & & & $14-2$ to 15.5 & $15, \mathrm{CC}$ & $28, \mathrm{CC}$ to $32, \mathrm{CC}$ & & & \\
\hline & & $\mathrm{NN} 13$ & & & $21 . \mathrm{CC}$ to $25 . \mathrm{CC}$ & Washed & \multirow{2}{*}{$15, \mathrm{CC}$ to $17-3$} & $16, \mathrm{CC}$ & \multirow{2}{*}{$33 . \mathrm{CC}$ to $35-2$} & & \multirow{2}{*}{$33 . \mathrm{CC}$ to $34, \mathrm{CC}$} & \\
\hline & & $\mathrm{NN} 12$ & & & & & & & & & & \\
\hline \multirow{9}{*}{ Miocene } & \multirow{2}{*}{ late } & NNII & & & $26-2$ to $30, \mathrm{CC}$ & $21-2$ to $26, \mathrm{CC}$ & $17 . \mathrm{CC}$ to $22 . \mathrm{CC}$ & & $35, \mathrm{CC}$ to $42 . \mathrm{CC}$ & & $35, \mathrm{CC}$ to $38, \mathrm{CC}$ & \\
\hline & & $\begin{array}{l}\text { NN10 } \\
\text { NN9 }\end{array}$ & & & & & $32,124 \mathrm{CC}$ & & & & & \\
\hline & \multirow{4}{*}{ middle } & NN8 & & & & & \multirow{2}{*}{25.2 to 28.2} & & & & & \\
\hline & & NN7 & & & & & & & & & & \\
\hline & & NN6 & & & & & 28.4 to 32.5 & & & & & \\
\hline & & NNS & & & & & $32, \mathrm{CC}$ to $35, \mathrm{CC}$ & & & & & \\
\hline & \multirow{4}{*}{ early } & NN4 & & & & & $36-2$ to $38-4$ & & & & & \\
\hline & & NN3 & & & & & 38.CC to $43-2$ & & & & & \\
\hline & & $\mathrm{NN}_{2}$ & & & & & $43-4$ to $44, \mathrm{CC}$ & & & & & \\
\hline \multirow{5}{*}{ Oligocene } & & NNI & & & & & $45-2$ to $45 . \mathrm{CC}$ & & & & & \\
\hline & \multirow[t]{2}{*}{ late } & NP2S & & & & & $46-2$ to $48, \mathrm{CC}$ & & & & & \\
\hline & & NP24 & & & & & $49-2$ to $49-4$ & & & & & \\
\hline & \multirow{2}{*}{ early } & $\mathrm{NP}_{23}$ & & & & & \multirow{3}{*}{ Missing } & & & & & \\
\hline & & NP21 & & & & & & & & & & \\
\hline \multirow{4}{*}{ Eocene } & \multirow{3}{*}{ late } & NP20 & & & & & & & & & & \\
\hline & & NP19 & & & & & $50-2$ to $52, \mathrm{CC}$ & & & & & \\
\hline & & NP18 & & & & & $53-1$ to 54.4 & & & & & \\
\hline & early & NP17 & & & & & $55 . \mathrm{CCC}$ to 57.3 & & & & & \\
\hline
\end{tabular}

of Discoaster brouweri, Samples 3,CC through 9,CC are assigned to NN19 (Pseudoemiliania lacunosa Zone). Below these samples, discoasters are found continuously, therefore, the Pliocene/Pleistocene boundary is placed between samples $9, \mathrm{CC}$ and 10,CC.

Samples $10, \mathrm{CC}$ and $11, \mathrm{CC}$ are assigned to the latest Pliocene Discoaster brouweri Zone (NN18). In this zone, $D$. brouweri and D. triradiatus are found. Sample 12,CC contains $D$. brouweri together with $D$. pentaradiatus. This sample may thus represent the late Pliocene Discoaster pentaradiatus Zone (NN17). Samples from 13,CC on down to 18,CC are assigned to NN16 (Discoaster surculus Zone) and contain an assemblage rich in asteroliths. Reticulofenestra pseudoumbilica occurs sporadically throughout this zone. Its abundance, however, drastically increases in Sample 19,CC. Therefore, specimens in NN16 are regarded as reworked, and Samples 19,CC and $20, \mathrm{CC}$ are placed in NN15 (Reticulofenestra pseudoumbilica Zone). Samples 21-2, 47-48 cm through 26,CC, which were obtained after washing down to $258.3 \mathrm{~m}$ subbottom, contain Discoaster quinqueramus and are referred to the Discoaster quinqueramus Zone (NN11).

\section{Site 608}

This site is on the southern flank of the King's Trough tectonic complex. The first hole (Hole 608) was continuously cored (HPC to refusal and then XCB) to basement of middle Eocene age in order to elucidate the tectonic history of the King's Trough. Hole 608A was continuously HPC cored, providing overlap to refusal. At this site Quaternary, Pliocene, Miocene, upper Oligocene, and upper to middle Eocene sediments were identified by calcareous nannofossil stratigraphy.

\section{Hole 608}

\section{Neogene (Table 7)}

The youngest coccolith assemblages at this site belong to the Emiliania huxleyi Zone (NN21) and are present in Samples 1-2, 46-47 cm and 1-4, 46-47 cm, where abundant Emiliania huxleyi and Gephyrocapsa oceanica occur together. Samples 1-5, 46-47 cm to 2-2, 46-47 cm are assigned to the Gephyrocapsa oceanica Zone (NN20) based on the absence of E. huxleyi and Pseudoemiliania lacunosa. The presence of abundant $P$. lacunosa and the absence of discoasters place Samples $2-3,46-47 \mathrm{~cm}$ to 5-4, 46-47 cm in NN19 (Pseudoemiliania lacunosa Zone). Helicosphaera inversa is found only in Samples 1-4, 46$47 \mathrm{~cm}$ to $2-3,46-47 \mathrm{~cm}$. Reticulofenestra sp. A and Reticulofenestra sp. B occur in Samples 3-2, 46-47 cm to 3-5, 46-47 cm. Similarly, Gephyrocapsa larger than $6 \mu \mathrm{m}$ is found in Samples 3-6, 46-47 cm, 3,CC, and 4-2, 46$47 \mathrm{~cm}$. Gephyrocapsa parallela is recognized above Sample 3-1, 46-47 cm. The last appearance datum (LAD) of 
Table 2 (continued).

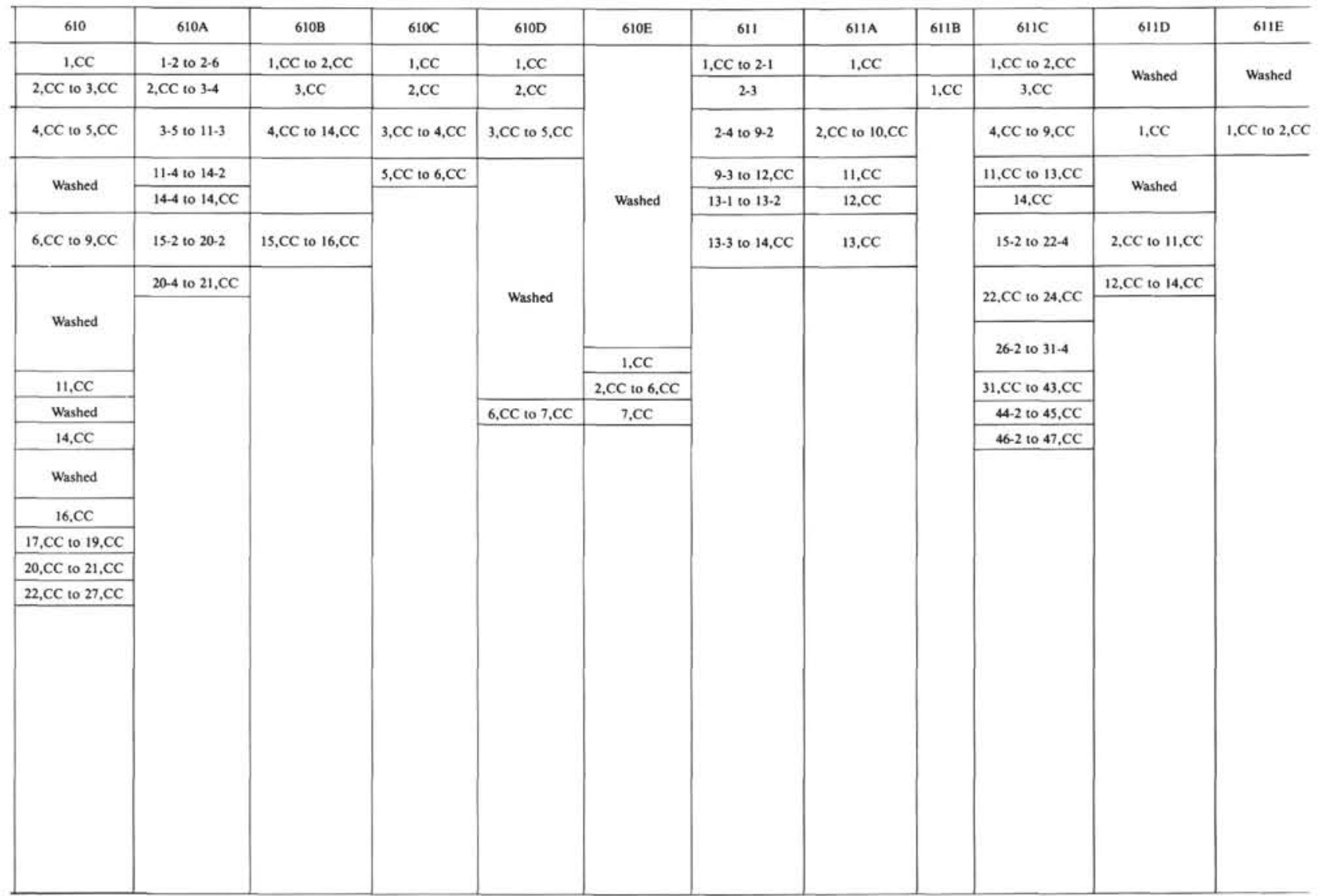

Helicosphaera sellii and Calcidiscus macintyrei, and the first appearance datums (FADs) of Gephyrocapsa oceanica and $G$. caribbeanica are in Zone NN19.

The Pliocene/Pleistocene boundary is between Samples 5-4, 46-47 cm and 5-5, 46-47 cm. Samples 5-5, 46$47 \mathrm{~cm}$ and 5-6, 46-47 cm contain Discoaster brouweri and are assigned to the latest Pliocene Discoaster brouweri Zone (NN18). The assemblage in the next lower sample $(5, \mathrm{CC})$ is characterized by the occurrences of Discoaster brouweri, D. pentaradiatus, and D. surculus, which places this sample in the Discoaster surculus Zone (NN16). The Disoaster pentaradiatus Zone (NN17) is, therefore, not recognized. Remarkably, there are only few discoasters in Samples 6-2, 46-47 cm through 7,CC, and the presence of Pseudoemiliania lacunosa and the absence of Gephyrocapsa caribbeanica and G. oceanica seem to place these samples again in the lowest part of Zone NN19. Discoasters in these samples are probably reworked. The co-occurrence of Discoaster brouweri, $D$. pentaradiatus, and D. surculus places Samples 8-2, 46$47 \mathrm{~cm}$ through $12-4,46-47 \mathrm{~cm}$ in NN16. NN16 and the lowest part of NN19 are repeated in this hole, as is evident from Table 7. This repetition is attributed to redeposition or small-scale slumping. Discoaster tamalis occurs only in and below Sample 10-4, 46-47 cm in this zone. Although Reticulofenestra pseudoumbilica is observed in the overlying zones, this species occurs consistently below Sample 12,CC. Thus Samples $12, \mathrm{CC}$ to
13, CC are assigned to the Reticulofenestra pseudoumbilica Zone (NN15). Sphenolithus abies occurs in Sample 13-2, 46-47 cm, somewhat below the NN16/NN15 boundary. The assemblage in Samples $14-2,46-47 \mathrm{~cm}$ to $15-5,46-47 \mathrm{~cm}$ is characterized by sporadic occurrences of Amaurolithus tricorniculatus, A. primus, A. delicatus, and Discoaster asymmetricus; this places these samples in the early Pliocene Discoaster asymmetricus Zone (NN14). The underlying NN13 Ceratolithus rugosus Zone and NN12 Amaurolithus tricorniculatus Zone cannot be distinguished because ceratoliths are very rare or absent. Thus Samples 15,CC through 17-3, 46-47 cm are tentatively placed in NN13-NN12. Based on the occurrences of Discoaster quinqueramus, NN11 (Discoaster quinqueramus Zone) is represented from Sample $17, \mathrm{CC}$ on down to Sample 22,CC. The first appearance datums (FADs) of Discoaster pentaradiatus and D. surculus are recognized in this zone. Although the number of specimens is very limited, the occurrence of Discoaster hamatus seems to place Samples $23-2,46-47 \mathrm{~cm}$ through $24, \mathrm{CC}$ in NN9 (Discoaster hamatus Zone). Therefore NN10 (Discoaster calcaris Zone) is not recognized clearly in this hole. Throughout the section ranging from Samples 25-2, 46$47 \mathrm{~cm}$ down to $32-5,26-27 \mathrm{~cm}$, age-diagnostic species are few. In this interval, however, the LADs of Coccolithus miopelagicus (between Samples 26-3, 46-47 cm and 26-4, 46-47 cm) and of Cyclicargolithus floridanus (between 28-2, 46-47 cm and 28-4, 36-37 cm) are clearly 
Table 3. Distribution of calcareous nannofossils, Hole 606 .

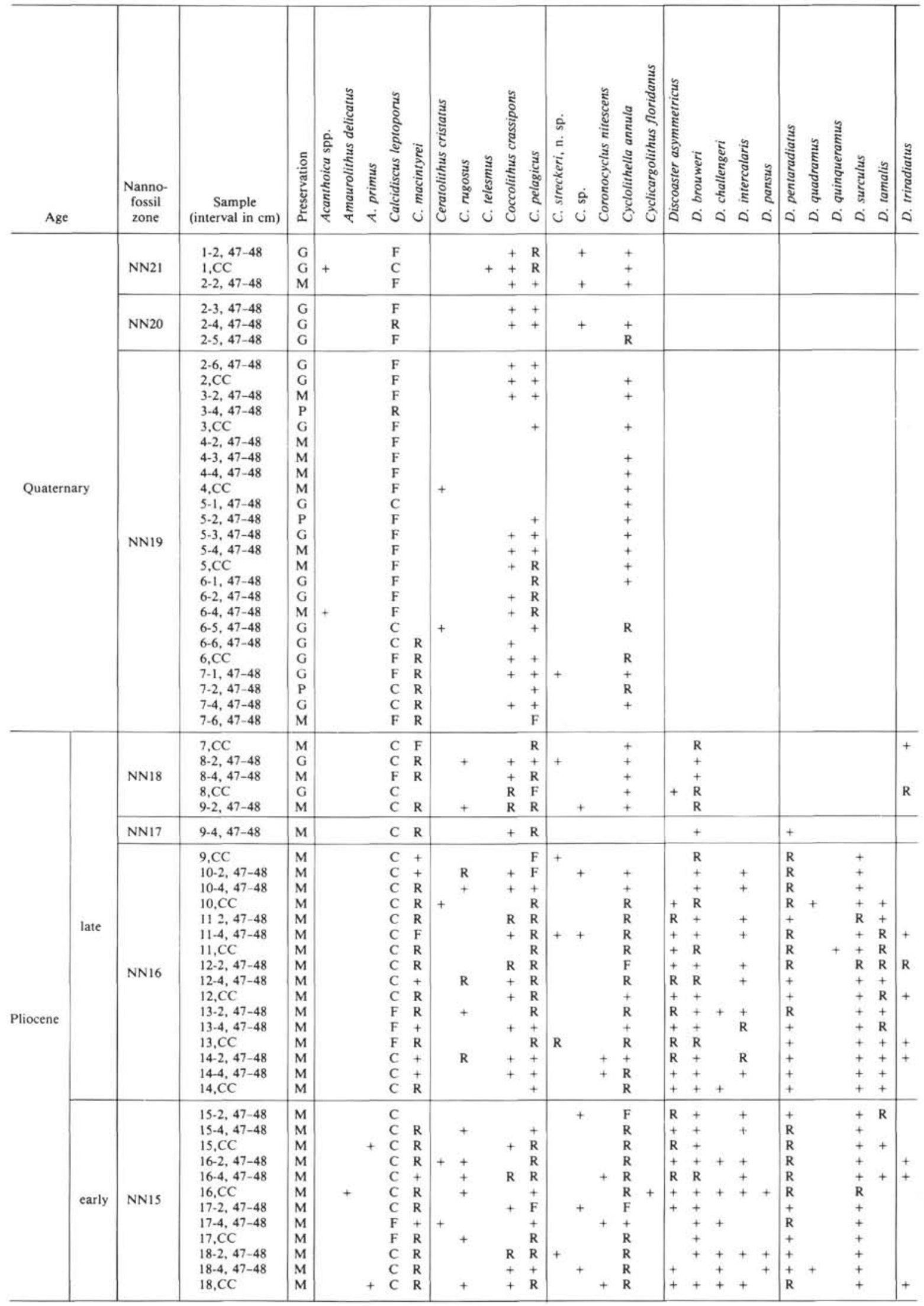

Note: $\mathrm{A}=$ abundant, $\mathrm{C}=$ common, $\mathrm{F}=$ few, $\mathrm{R}=$ rare, $+=$ present $\mathrm{G}=$ good, $\mathrm{M}=$ moderate, $\mathrm{P}=$ poor. 


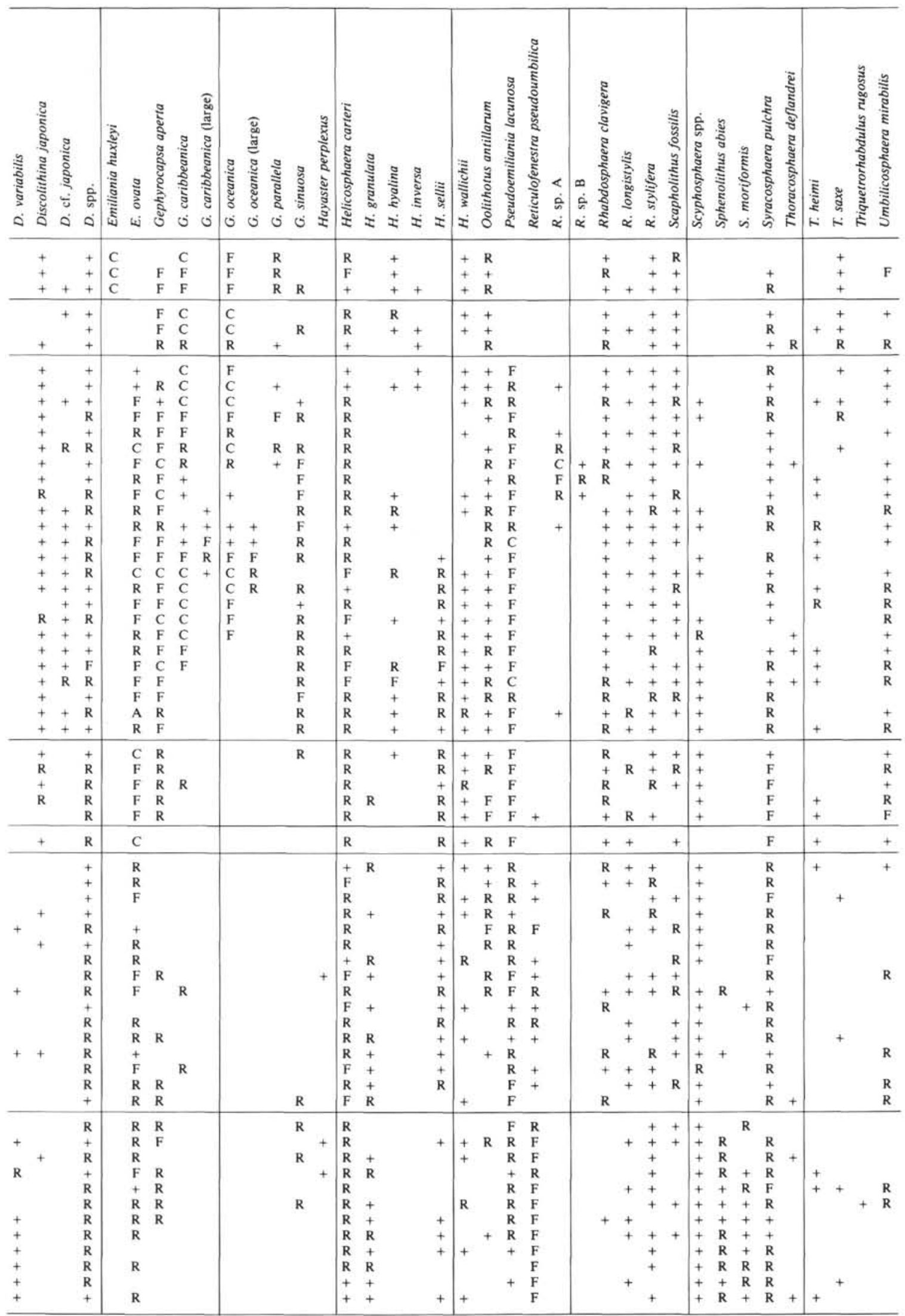


Table 4. Distribution of calcareous nannofossils, Hole 606A

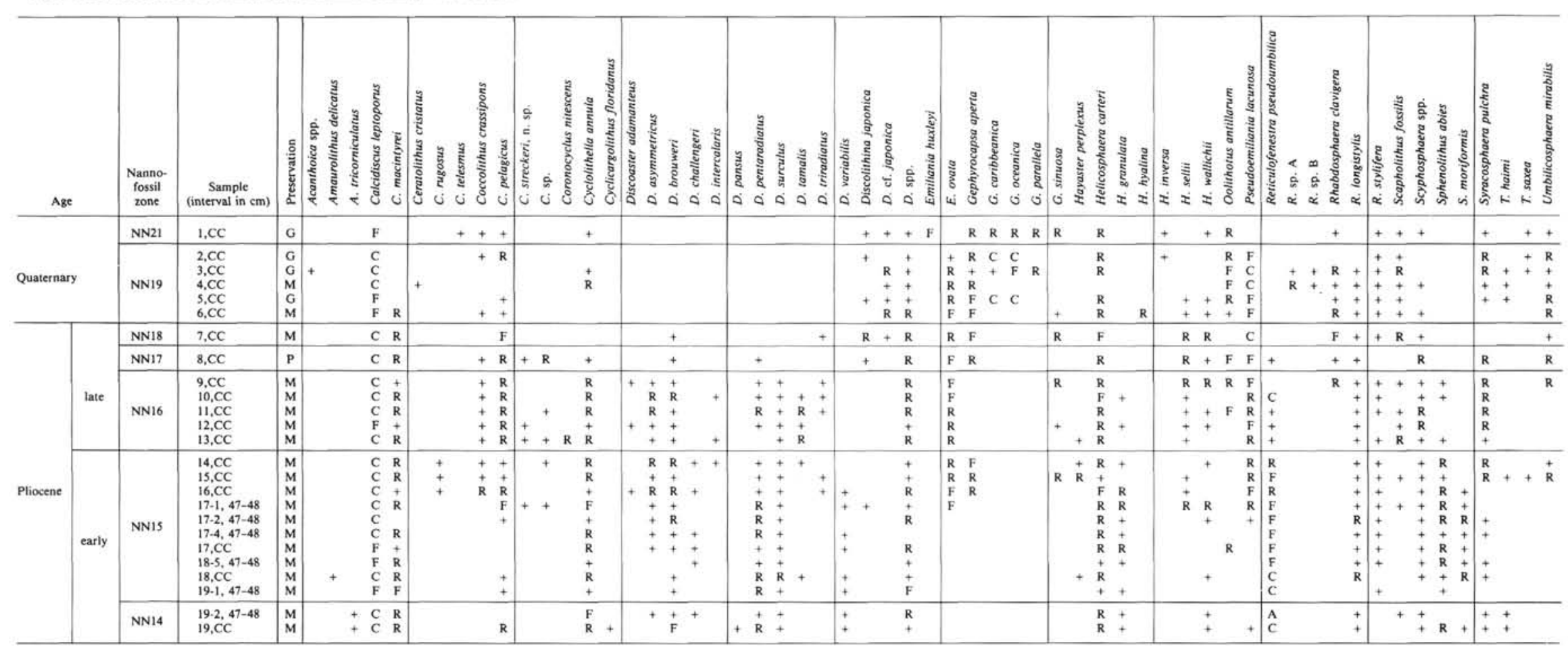

Note: For explanation of symbols see Table 3 and text. 
recognizable. According to Bukry's (1973) zonation, the LAD of Cyclicargolithus floridanus coincides with the FAD of Discoaster kugleri, which marks the boundary between NN7 (Discoaster kugleri Zone)/NN6 (Discoaster exilis Zone). Sphenolithus heteromorphus occurs continuously below Sample 32, CC, and Samples 32, CC to $35, \mathrm{CC}$ are placed in NN5 (Sphenolithus heteromorphus Zone). Helicosphaera ampliaperta first occurs in Sample 36-2, 46-47 cm, and the first occurrence of Sphenolithus belemnos is recognized in Sample 38,CC. Thus Samples 36-2, 46-47 cm through 38-4, 46-47 cm and Samples $38, C C$ through $43-2,46-47 \mathrm{~cm}$ are assigned to the early Miocene Helicosphaera ampliaperta Zone (NN4) and Sphenolithus belemnos Zone (NN3), respectively. Triquetrorhabdulus carinatus is present in the overlying zones, but this species occurs continuously below Sample 43-4, 46-47 cm together with Discoaster druggii, which identifies the early Miocene Discoaster druggii Zone (NN2). Samples 45-2, 44-45 cm through 45,CC contain no Discoaster druggii; these samples may thus be assigned to the earliest Miocene Triquetrorhabdulus carinatus Zone (NN1).

\section{Paleogene (Table 8)}

There is a remarkable change in species composition of calcareous nannofossils between Samples 44,CC and $45-2,44-45 \mathrm{~cm}$ (Table 7). In contrast to the previous samples, sediments below Sample 45-2, 44-45 cm contain abundant Dictyococcites bisectus together with $C y$ clicargolithus abisectus, C. floridanus, Coccolithus pelagicus, C. miopelagicus, Sphenolithus ciperoensis, and $S$. moriformis. The marker species Helicosphaera recta is very rare; therefore the Neogene/Paleogene boundary (NN1/NP25) is tentatively placed between Samples 45,CC and 46-2, 46-47 cm, based on the LAD of Sphenolithus ciperoensis. This species is found in Samples 46-2, 46$47 \mathrm{~cm}$ through $49-4,46-47 \mathrm{~cm}$. Sphenolithus distentus occurs together with $S$. ciperoensis below Sample 49-2, $46-47 \mathrm{~cm}$. Therefore the boundary between the late Oligocene Sphenolithus ciperoensis Zone (NP25) and Sphenolithus distentus Zone (NP24) is placed between Samples $48, C C$ and $49-2,46-47 \mathrm{~cm}$.

There is another remarkable change in species composition between Samples 49-4, 46-47 cm and 50-2, 46$47 \mathrm{~cm}$. Below Sample 50-2, 46-47 cm, calcareous nannofossils are represented by abundant Eocene assemblages with relatively low species diversity. Samples 50-2, 46-47 $\mathrm{cm}$ through 52,CC are assigned to the late Eocene Isthmolithus recurvus Zone (NP19) based on the occurrences of Isthmolithus recurvus, Discoaster barbadiensis, D. saipanensis, D. tani nodifer, Chiasmolithus oamaruensis, and Calcidiscus formosus. Samples $53-1,42-43 \mathrm{~cm}$ through $54-4,46-47 \mathrm{~cm}$ are all placed in the Chiasmolithus oamaruensis Zone (NP18) based on the absence of Isthmolithus recurvus. The lowest three samples recovered from the bottom of this hole contain Chiasmolithus grandis and no $C$. oamaruensis and are placed in the Discoaster saipanensis Zone (NP17). The geological age of the sediments at the bottom of this hole is middle Eocene.
Samples 49,CC and 50-1, 36-37 cm contain the following species: Calcidiscus formosus, Cyclicargolithus floridanus, C. abisectus, Discoaster barbadiensis, Helicosphaera euphratis, $H$. perch-nielseniae, Isthmolithus recurvus, Reticulofenestra hillae, $R$. umbilica, Sphenolithus distentus, $S$. predistentus, and Chiasmolithus oamaruensis. These species constitute a mixed assemblage of the Sphenolithus distentus Zone (NP19) and Isthmolithus recurvus Zone (NP24). The Sphenolithus predistentus Zone (NP23) through Sphenolithus pseudoradians Zone (NP20) are missing; therefore, a middle Oligocene to late Eocene hiatus occurs at this site. The calcareous nannofossil mixed interval referred to earlier is attributed to this hiatus.

\section{Hole 608A (Table 9)}

Sample 1,CC is assigned to the Emiliania huxleyi Zone (NN21), because Emiliania huxleyi and gephyrocapsid specimens are dominant. Based on the presence of Pseudoemiliania lacunosa and the absence of discoasters, Samples 2,CC to 5,CC belong to the Pseudoemiliania lacunosa Zone (NN19).

In contrast to the previous hole, the Pliocene/Pleistocene boundary is sharply marked between Samples 5,CC and 6,CC. Sample 6,CC, in which Discoaster brouweri is found, is assigned to NN18 (Discoaster brouweri Zone). The occurrence of $D$. pentaradiatus together with $D$. surculus indicates NN16 (Discoaster surculus Zone) for Samples 7,CC to 12,CC. The abundance of Reticulofenestra pseudoumbilica drastically increases in Sample 13,CC, and Samples 13,CC and 14,CC belong to the Reticulofenestra pseudoumbilica Zone (NN15). Sample 15,CC contains Amaurolithus tricorniculatus and Discoaster asymmetricus and is assigned to the Discoaster asymmetricus Zone (NN14). Because of the absence of D. asymmetricus, Sample 16,CC may be placed in the Ceratolithus rugosus Zone (NN13).

\section{Site 609}

Site 609 is located on the upper-middle part of the eastern flank of the Mid-Atlantic Ridge. Four holes were drilled at this site. Continuous sequences were obtained down to the upper Miocene from Holes 609 and 609B. Holes $609 \mathrm{~A}$ and $609 \mathrm{C}$ cover coring gaps in the upper Pleistocene and upper Pliocene, respectively. All sediments yielded abundant calcareous nannofossils in good to moderate states of preservation and moderate to high diversity; an almost complete sequence was recovered ranging from late Pleistocene-Holocene NN21 (Emiliania huxleyi Zone) to late Miocene NN11 (Discoaster quinqueramus Zone). Because of discontinuous occurrences of some marker species, however, the zonal boundaries were difficult to establish in the lower Pliocene.

\section{Hole 609 (Table 10)}

Samples 1-2, 43-45 cm through 2-2, 43-45 cm are assigned to the Emiliania huxleyi Zone (NN21). The next lower sample is at $2-5,43-45 \mathrm{~cm}$ and is barren of coccoliths. Based on the absence of Emiliania huxleyi and Pseudoemiliania lacunosa, Samples 2, CC to 3-4, 43-45 
Table 5. Distribution of calcareous nannofossils, Hole 607.

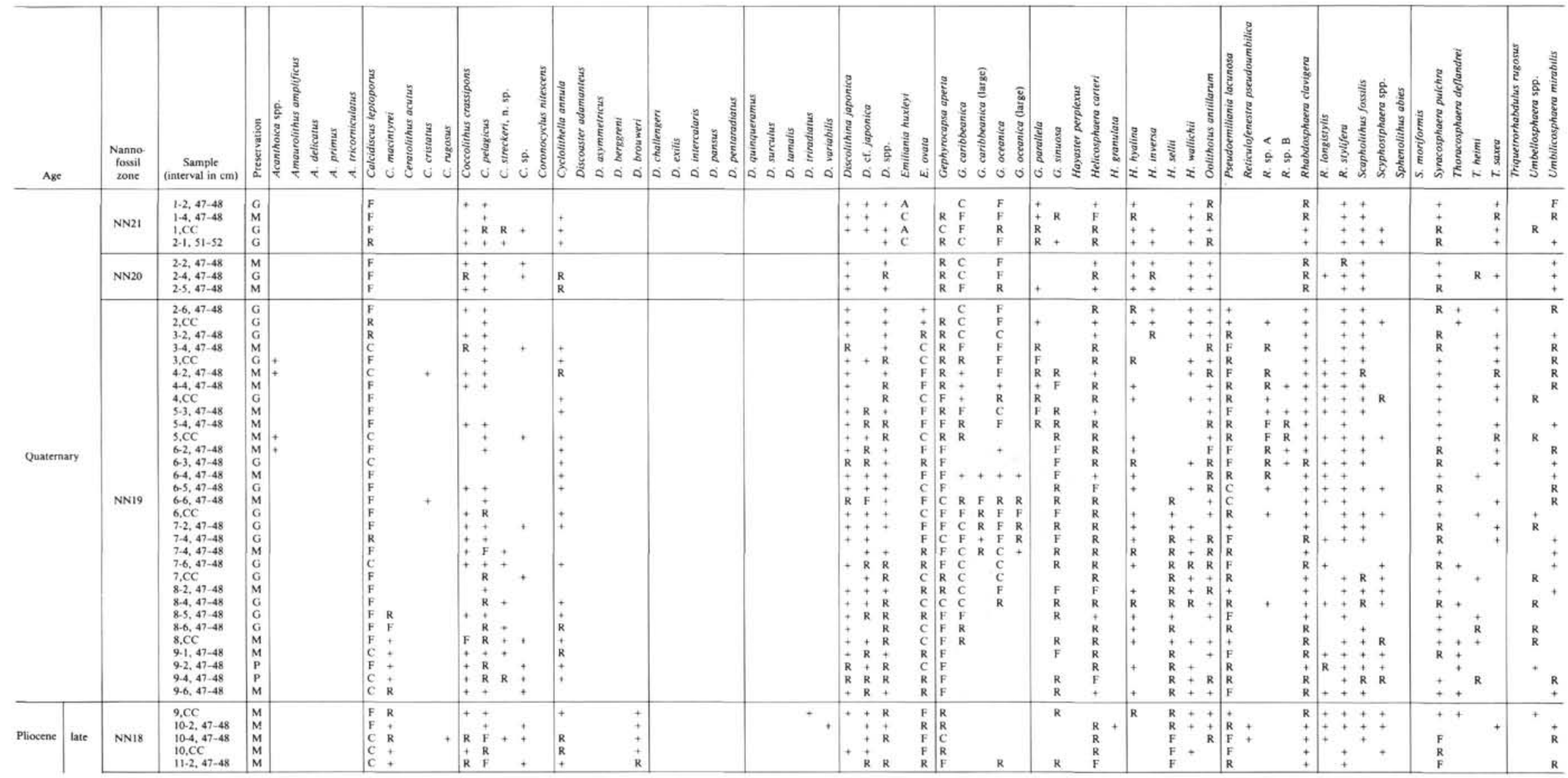




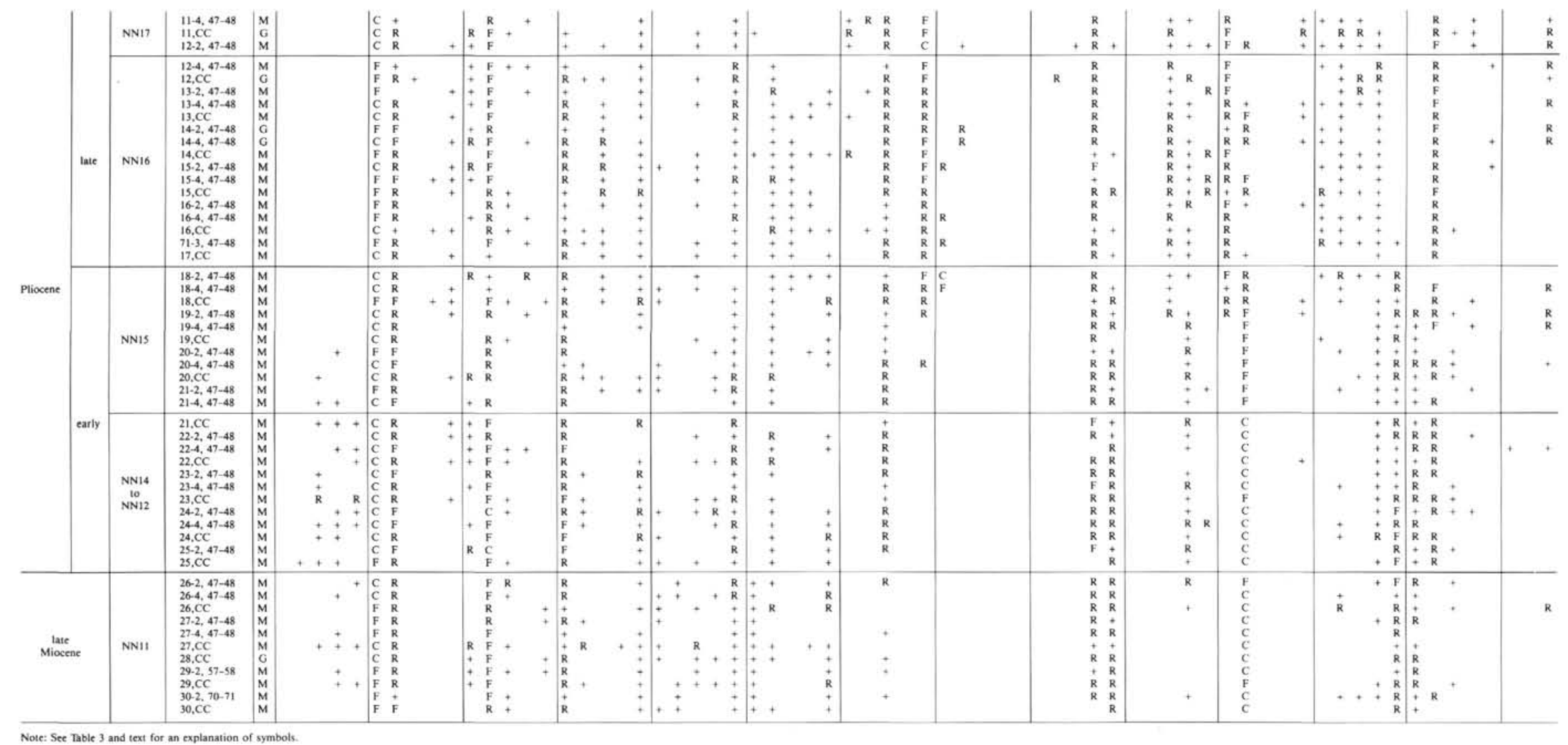


Table 6. Distribution of calcareous nannofossils, Hole 607A.

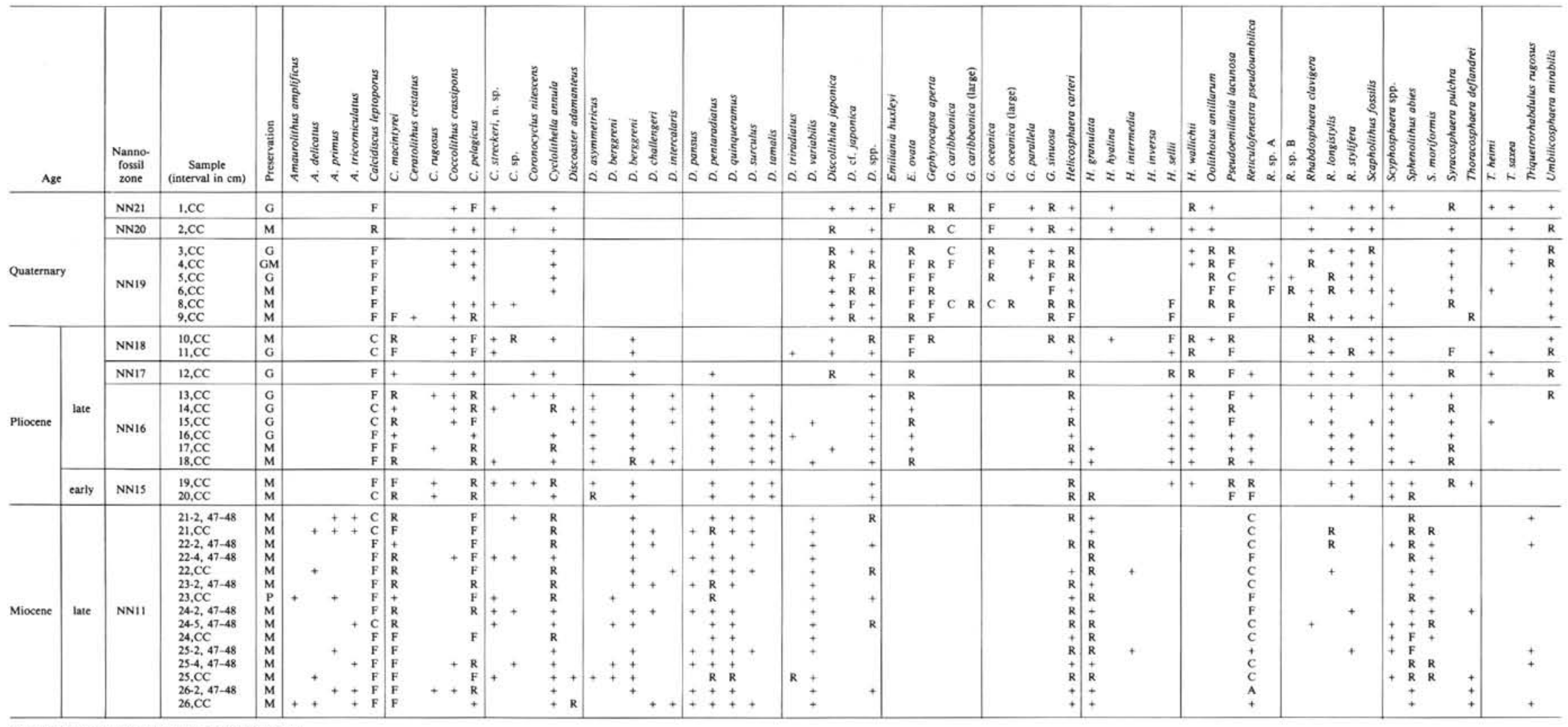

Note: For an explanation of symbols, see Table 3 and text. 
$\mathrm{cm}$ are placed in NN20 (Gephyrocapsa oceanica Zone). Helicosphaera inversa occurs in the lower part of this zone. Samples 3,CC through 15-2, 43-45 cm contain abundant Pseudoemiliania lacunosa and no discoasters, which places this interval in NN19 (Pseudoemiliania lacunosa Zone). Helicosphaera inversa is also found in the uppermost part of this zone. Among these samples, Samples 6,CC down to 9-2, 43-45 cm contain fairly abundant Reticulofenestra sp. A. Gephyrocapsa parallela is found only in and above Sample 6-4, 43-45 cm. Comparatively large Gephyrocapsa are concentrated in the middle of this zone. Helicosphaera sellii and Calcidiscus macintyrei are found as high as Samples 9-4, 43-45 cm and 12,CC, respectively. The interval below Sample 12,CC contains no Gephyrocapsa oceanica and samples below $13-4,43-45 \mathrm{~cm}$ only yield Gephyrocapsa aperta and $G$. sinuosa.

The Pliocene/Pleistocene boundary is placed between Samples $15-2,43-45 \mathrm{~cm}$ and $15-4,43-45 \mathrm{~cm}$. As at the previous sites, the nannoflora changes progressively below this boundary with an increasing abundance of discoasters. The assemblage in Samples 15-4, 43-45 cm through 19,CC is characterized by the occurrence of Discoaster brouweri; this assemblage places these samples in the late Pliocene Discoaster brouweri Zone (NN18). The presence of $D$. brouweri and $D$. pentaradiatus in Samples 20-1, 43-45 cm and 20-4, 43-45 cm places these samples in NN17 (Discoaster pentaradiatus Zone). Samples $20, \mathrm{CC}$ through $26, \mathrm{CC}$ contain comparatively diversified discoaster species such as Discoaster brouweri, $D$. pentaradiatus, $D$. surculus, and $D$. asymmetricus. Therefore these samples are assigned to the late Pliocene Discoaster surculus Zone (NN16). In this zone, Discoaster tamalis is recognized in Samples 24-1, 43-45 cm through 25 , CC. Reticulofenestra pseudoumbilica occurs sporadically throughout NN16. This species, however, is first found abundantly in Sample $27-2,43-45 \mathrm{~cm}$, and thus this sample marks the top of the early Pliocene Reticulofenestra pseudoumbilica Zone (NN15). Sphenolithus abies occurs in Sample 26,CC, slightly above the NN16/ NN15 boundary. Samples 28,CC through 32,CC contain Amaurolithus tricorniculatus and Discoaster asymmetricus and are assigned to NN14 (Discoaster asymmetricus Zone). The distinction between NN13 (Ceratolithus rugosus Zone) and NN12 (Amaurolithus tricorniculatus Zone) is uncertain. Sample 35, CC down to the bottom of this hole is assigned to the late Miocene Discoaster quinqueramus Zone (NN11) because of the presence of the nominate species, $D$. quinqueramus.

\section{Hole 609A (Table 11)}

In this hole only two core-catcher samples were examined. These samples contain abundant Pseudoemiliania lacunosa. As a single specimen of Discoaster brouweri in Sample 1,CC is regarded as reworked, these samples are assigned to the Pleistocene Pseudoemiliania lacunosa Zone (NN19). In these samples, Calcidiscus macintyrei and Helicosphaera sellii were not found.

\section{Hole 609B (Table 12)}

Nannofossil assemblages in this hole are similar to those in Hole 609. The abundant occurrence of Emilia- nia huxleyi suggests that Samples 1,CC and 2,CC can be correlated with NN21 (Emiliania huxleyi Zone). Sample 3,CC is placed in NN20 (Gephyrocapsa oceanica Zone) because Emiliania huxleyi and Pseudoemiliania lacunosa are absent. Samples 4,CC through 15,CC belong to NN19 (Pseudoemiliania lacunosa Zone) because of the presence of Pseudoemiliania lacunosa and the absence of discoasters. Helicosphaera sellii and Calcidiscus macintyrei are found only in the lower part of this zone. Comparatively large specimens of Gephyrocapsa caribbeanica and $G$. oceanica occur in the middle of this zone. G. parallela occurs above Sample 5,CC.

Cores 16 and 17 are assigned to the latest Pliocene Discoaster brouweri Zone (NN18). Discoaster brouweri is present throughout, and $D$. triradiatus is found in Sample 16,CC. From sample 19,CC on down to Sample $27, \mathrm{CC}$, the Discoaster surculus Zone (NN16) is represented by an assemblage rich in asteroliths, including Discoaster brouweri, D. pentaradiatus, D. surculus, as well as $D$. challengeri. Discoaster asymmetricus is present throughout this zone. Discoaster tamalis occurs in Samples 24,CC and 25,CC. Reticulofenestra pseudoumbili$c a$ is continuously found below Sample 21,CC. The abundance of this species, however, increases drastically in Sample 28,CC. We interpret this as the top of the acme of this species and designate it as the top of the Reticulofenestra pseudoumbilica Zone (NN15). The NN14 (Discoaster asymmetricus Zone)/NN13 (Ceratolithus rugosus Zone) boundary is placed between Samples 32,CC and 33,CC based on the lowest occurrence of Discoaster asymmetricus in Sample 32,CC. From Sample 35,CC on down to the bottom of this hole the Discoaster quinqueramus Zone (NN11) seems to be represented, although typical Discoaster quinqueramus is still rare at this level. Because ceratoliths are rare, the NN15/NN14 and NN13/ NN12 boundaries are not clear in this hole.

\section{Hole 609C (Table 13)}

Sample 1,CC contains abundant Pseudoemiliania lacunosa and no discoasters, which places this sample in NN19 (Pseudoemiliania lacunosa Zone). The sample also contains Calcidiscus macintyrei, Helicosphaera sellii, and no gephyrocapsids; therefore it is assigned to the earliest Pleistocene. The assemblage in Samples 2,CC and $4, C C$ is characterized by the occurrences of Caicidiscus leptoporus, Coccolithus pelagicus, Emiliania ovata, Helicosphaera carteri, $H$. sellii, Pseudoemiliania lacunosa, and Syracosphaera pulchra together with Discoaster brouweri. This assemblage places these samples in the late Pliocene Discoaster brouweri Zone (NN18), and the Pliocene/Pleistocene boundary is placed between Samples 1,CC and 2,CC. The co-occurrence of Discoaster brouweri and D. pentaradiatus in Sample 5,CC places that sample in NN17 (Discoaster pentaradiatus Zone). Samples 6,CC and 7,CC contain comparatively diversified discoaster species such as Discoaster asymmetricus, $D$. brouweri, $D$. pentaradiatus, $D$. surculus, and $D$. variabilis and they are assigned to the late Pliocene Discoaster surculus Zone (NN16). A few specimens of $R e$ ticulofenestra pseudoumbilica were recognized in these samples. 
Table 7. Distribution of Neogene calcareous nannofossils, Hole 608.

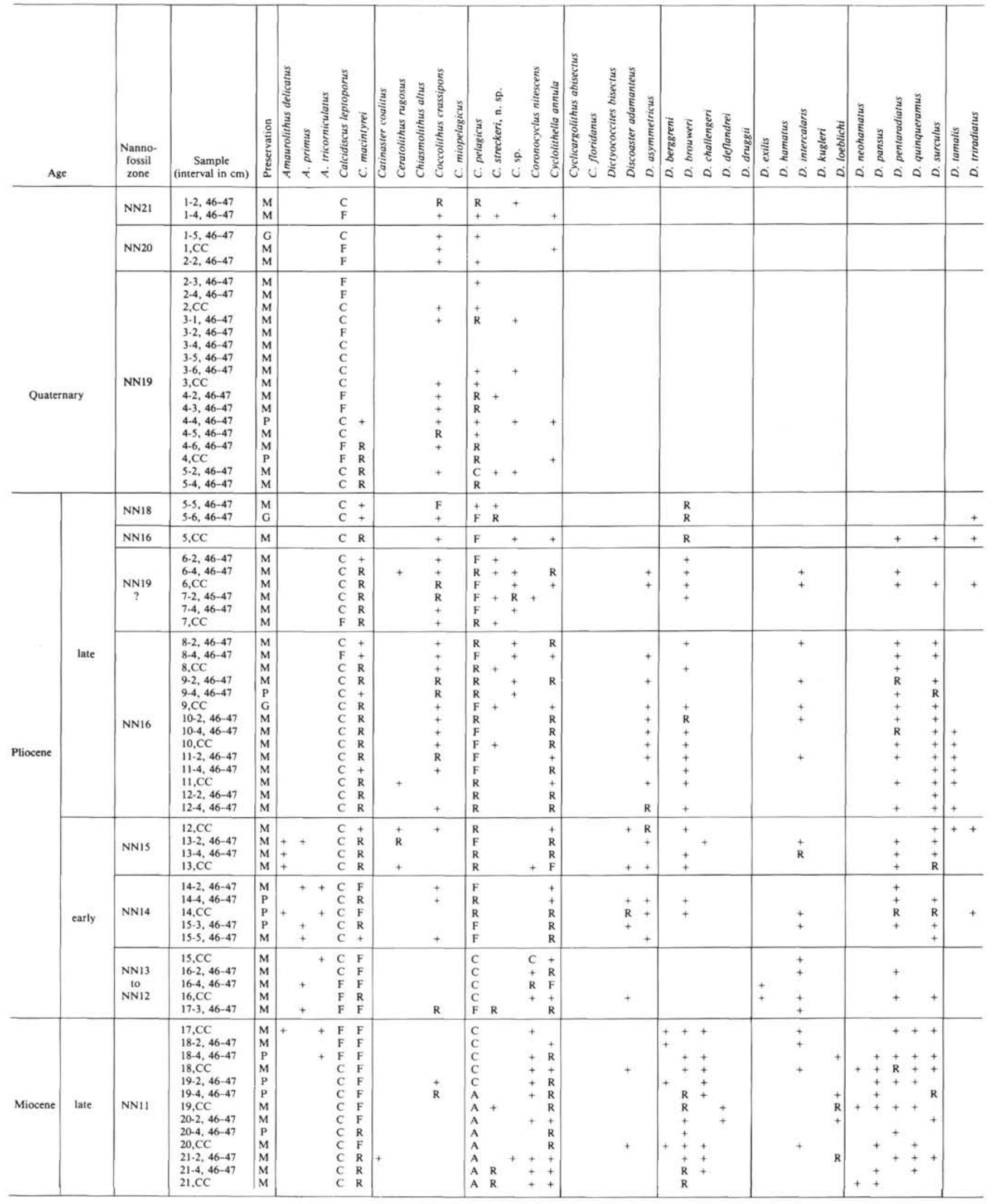

Note: For an explanation of symbols, see Table 3 and text. 
Table 7 (continued).

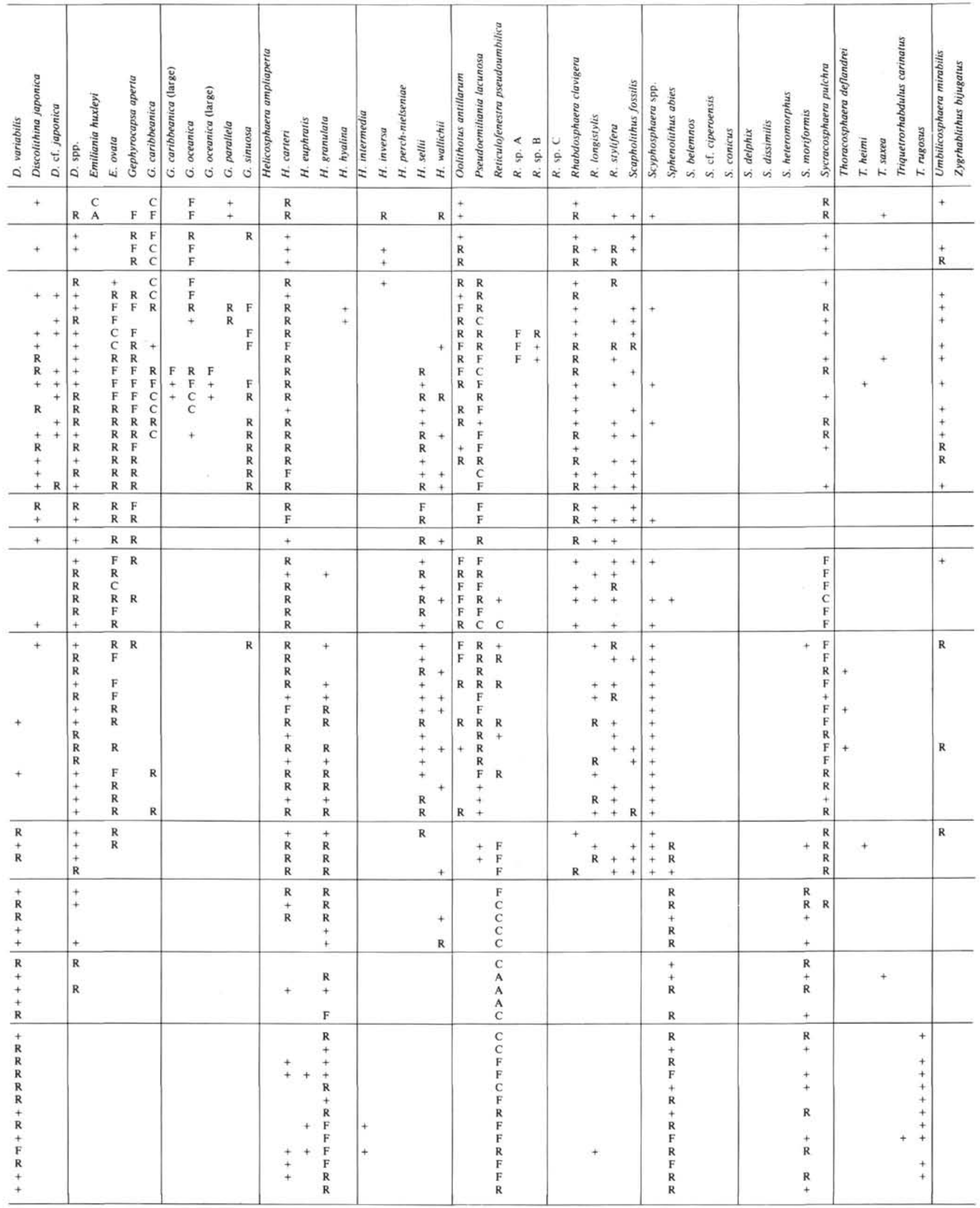


Table 7 (continued).

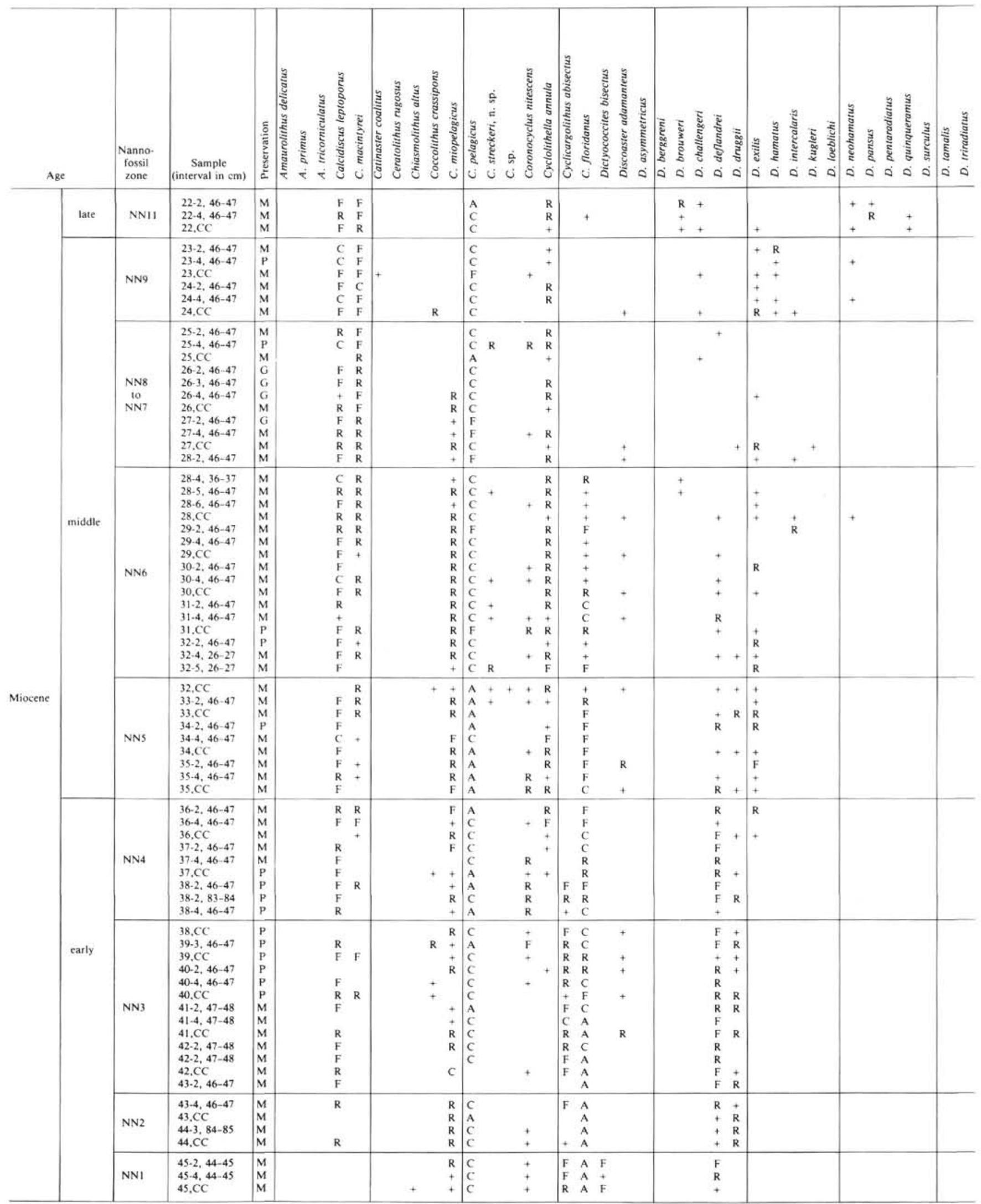


Table 7 (continued).

\begin{tabular}{|c|c|c|c|c|c|c|c|c|c|c|c|}
\hline 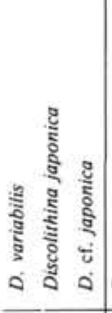 & 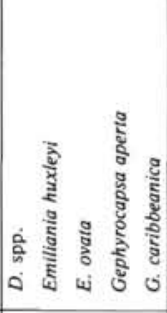 & 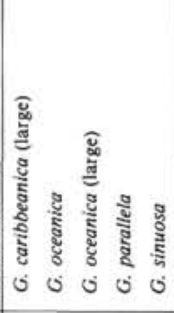 & 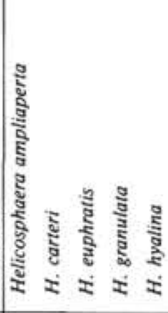 & 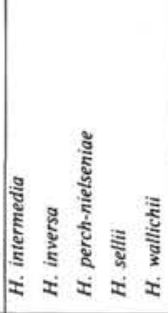 & 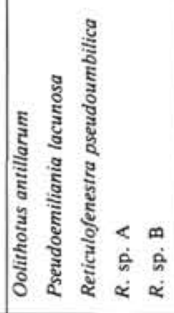 & 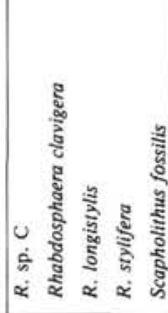 & 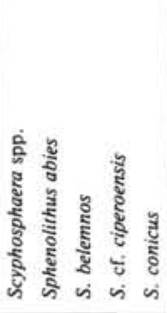 & & 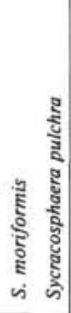 & 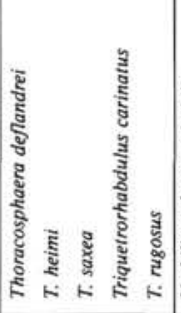 & 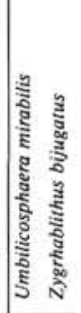 \\
\hline $\begin{array}{l} \pm \\
+ \\
\end{array}$ & + & & $\begin{array}{l}R \\
R \\
+\end{array}$ & + & $\begin{array}{l}F \\
R \\
F \\
F\end{array}$ & + & $\begin{array}{l}+ \\
+ \\
F\end{array}$ & & $\begin{array}{l}R \\
+ \\
+\end{array}$ & + & \\
\hline $\begin{array}{l}+ \\
+ \\
+ \\
R \\
F \\
R \\
\\
+ \\
\end{array}$ & + & & $\begin{array}{rr}+ \\
+\quad R \\
+\quad+ \\
+\quad F \\
\\
\quad R \\
\\
R\end{array}$ & & $\begin{array}{l}\mathrm{R} \\
\mathrm{R} \\
\mathrm{R} \\
\mathrm{F} \\
\mathrm{R} \\
\mathrm{F}\end{array}$ & $\begin{array}{l}+ \\
+ \\
+ \\
+ \\
+ \\
+\end{array}$ & $\begin{array}{l}\mathrm{F} \\
\mathrm{F} \\
\mathrm{F} \\
\mathrm{R} \\
+ \\
\mathrm{F}\end{array}$ & & $\begin{array}{l}+ \\
R \\
F \\
\text { R } \\
+ \\
\text { R } \\
\end{array}$ & + & \\
\hline $\begin{array}{l} \\
+ \\
+ \\
+ \\
+ \\
+ \\
\text { R } \\
+ \\
+ \\
+\end{array}$ & & & $\begin{array}{ccc}\mathrm{R} & \mathrm{R} & + \\
& \mathrm{R} \\
& \mathrm{R} \\
& + \\
& \mathrm{R} \\
& \mathrm{F} \\
& & \\
& & \\
& + & \mathrm{R} \\
& + & \mathrm{R} \\
\mathrm{R} & \mathrm{R} \\
\mathrm{R} & \mathrm{R}\end{array}$ & & $\begin{array}{l}\mathrm{F} \\
\mathrm{R} \\
\mathrm{F} \\
\mathrm{F} \\
\mathrm{C} \\
\mathrm{C} \\
+ \\
\mathrm{F} \\
\mathrm{F} \\
\mathrm{F} \\
\mathrm{C} \\
\mathrm{C}\end{array}$ & & $\begin{aligned}+F \\
F \\
R \\
F \\
F \\
R \\
R \\
F \\
+\quad F \\
R\end{aligned}$ & & $\begin{array}{l}\mathrm{F} \\
\mathrm{R} \\
+ \\
\mathrm{F} \\
\mathrm{R} \\
+ \\
+ \\
+ \\
+ \\
+\end{array}$ & $\begin{array}{r}+ \\
+ \\
+ \\
+ \\
++ \\
+ \\
\end{array}$ & \\
\hline $\begin{array}{l}\text { R } \\
R \\
R \\
+ \\
+ \\
R \\
+ \\
R \\
R \\
F \\
+ \\
R \\
+ \\
R \\
R \\
R \\
R \\
R \\
R\end{array}$ & & & 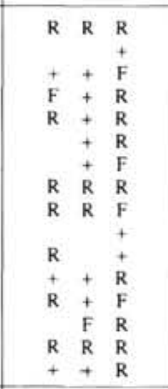 & R & $\begin{array}{l}\mathrm{F} \\
\mathrm{C} \\
\mathrm{F} \\
\mathrm{F} \\
\mathrm{C} \\
\mathrm{C} \\
\mathrm{C} \\
\mathrm{C} \\
\mathrm{F} \\
\mathrm{F} \\
\mathrm{C} \\
\mathrm{F} \\
\mathrm{C} \\
\mathrm{C} \\
\mathrm{F} \\
\mathrm{C} \\
\mathrm{C}\end{array}$ & t & $\begin{array}{r}\mathrm{F} \\
\mathrm{F} \\
\mathrm{F} \\
\mathrm{R} \\
+ \\
\mathrm{F} \\
\mathrm{F} \\
\mathrm{F} \\
\mathrm{R} \\
\mathrm{R} \\
\mathrm{R} \\
\mathrm{R} \\
\mathrm{R} \\
\mathrm{R} \\
\mathrm{F} \\
\mathrm{R} \\
\mathrm{F} \\
+\end{array}$ & & $\begin{array}{l}+ \\
R \\
R \\
+ \\
+ \\
+ \\
+ \\
R \\
R \\
+ \\
F \\
+ \\
+ \\
R \\
R \\
+ \\
\\
\end{array}$ & $\begin{array}{r}+ \\
+ \\
R \\
+ \\
+ \\
++ \\
+\quad+ \\
\\
\\
\\
\end{array}$ & \\
\hline $\begin{array}{l}+ \\
+ \\
+ \\
R \\
\text { R } \\
\text { F } \\
R \\
R \\
R \\
R \\
R\end{array}$ & $\begin{array}{l}\text { R } \\
+\end{array}$ & & 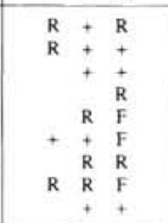 & + & $\begin{array}{l}C \\
C \\
C \\
F \\
C \\
R \\
R \\
R \\
R \\
R \\
F\end{array}$ & & $\begin{array}{l}\mathrm{F} \\
\mathrm{R} \\
\mathrm{R} \\
\mathrm{F} \\
\mathrm{R} \\
\mathrm{F} \\
\mathrm{R} \\
\mathrm{F}\end{array}$ & $\begin{array}{l}R \\
F \\
F \\
F \\
+ \\
R \\
F \\
R \\
R \\
R \\
R\end{array}$ & $\begin{array}{l}\text { R } \\
R \\
+ \\
+ \\
+ \\
R \\
\text { R } \\
F \\
\text { R }\end{array}$ & & \\
\hline $\begin{array}{l}\mathrm{F} \\
\mathrm{R} \\
\mathrm{F} \\
+ \\
+ \\
+ \\
+ \\
+\end{array}$ & & & 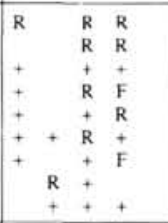 & $R$ & $\begin{array}{l}\mathrm{F} \\
\mathrm{F} \\
+ \\
\mathrm{F} \\
\mathrm{R} \\
\mathrm{C} \\
\mathrm{C} \\
\mathrm{C} \\
\mathrm{C} \\
\mathrm{F}\end{array}$ & & $\begin{array}{l}F \\
R \\
R \\
F \\
F \\
R \\
R \\
F\end{array}$ & $\begin{array}{ll} & F \\
& F \\
& F \\
& F \\
R & R \\
& R \\
& R \\
& R \\
+ & R\end{array}$ & $\begin{array}{l}\text { R } \\
F \\
F \\
F \\
\text { R } \\
\text { F } \\
R \\
R \\
\text { R } \\
F\end{array}$ & ++ & \\
\hline $\begin{array}{l}+ \\
+ \\
+\end{array}$ & & & 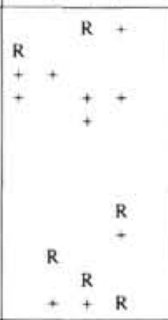 & & $\begin{array}{l}+ \\
c \\
c \\
R\end{array}$ & $\stackrel{R}{+}$ & $\begin{array}{ll}\mathrm{F} & \mathrm{F} \\
\mathrm{F} & \mathrm{R} \\
+ & + \\
\mathrm{R} & + \\
\mathrm{R} & + \\
\mathrm{F} & + \\
& \\
& \\
& \\
\mathrm{R} & \end{array}$ & $\begin{array}{l}\mathrm{R} \\
+ \\
+ \\
+ \\
+ \\
\mathrm{R} \\
\mathrm{R} \\
+ \\
+\end{array}$ & $\begin{array}{l}\mathrm{R} \\
R \\
R \\
+ \\
+ \\
\\
R \\
+ \\
+ \\
R \\
R \\
F \\
F\end{array}$ & $\begin{array}{l}+ \\
+ \\
+ \\
+ \\
+\end{array}$ & \\
\hline & & & $\begin{array}{l}{ }^{R} \\
{ }_{R}^{R} \\
R\end{array}$ & & & $\begin{array}{l}R \\
R\end{array}$ & & + & & $\begin{array}{l}+ \\
R \\
R \\
+\end{array}$ & \\
\hline & & & $\begin{array}{l}\mathrm{R} \\
+ \\
+\end{array}$ & $\begin{array}{ll}\vdots & \vdots \\
& +\end{array}$ & & $\begin{array}{l}\dot{R} \\
\mathrm{R}\end{array}$ & ${ }^{+}{ }^{+}$ & $\begin{array}{l}+\underset{C}{F} \\
C \\
C\end{array}$ & $\begin{array}{l}R \\
R \\
R\end{array}$ & + & \pm \\
\hline
\end{tabular}


Table 8. Distribution of Paleogene calcareous nannofossils, Hole 608.

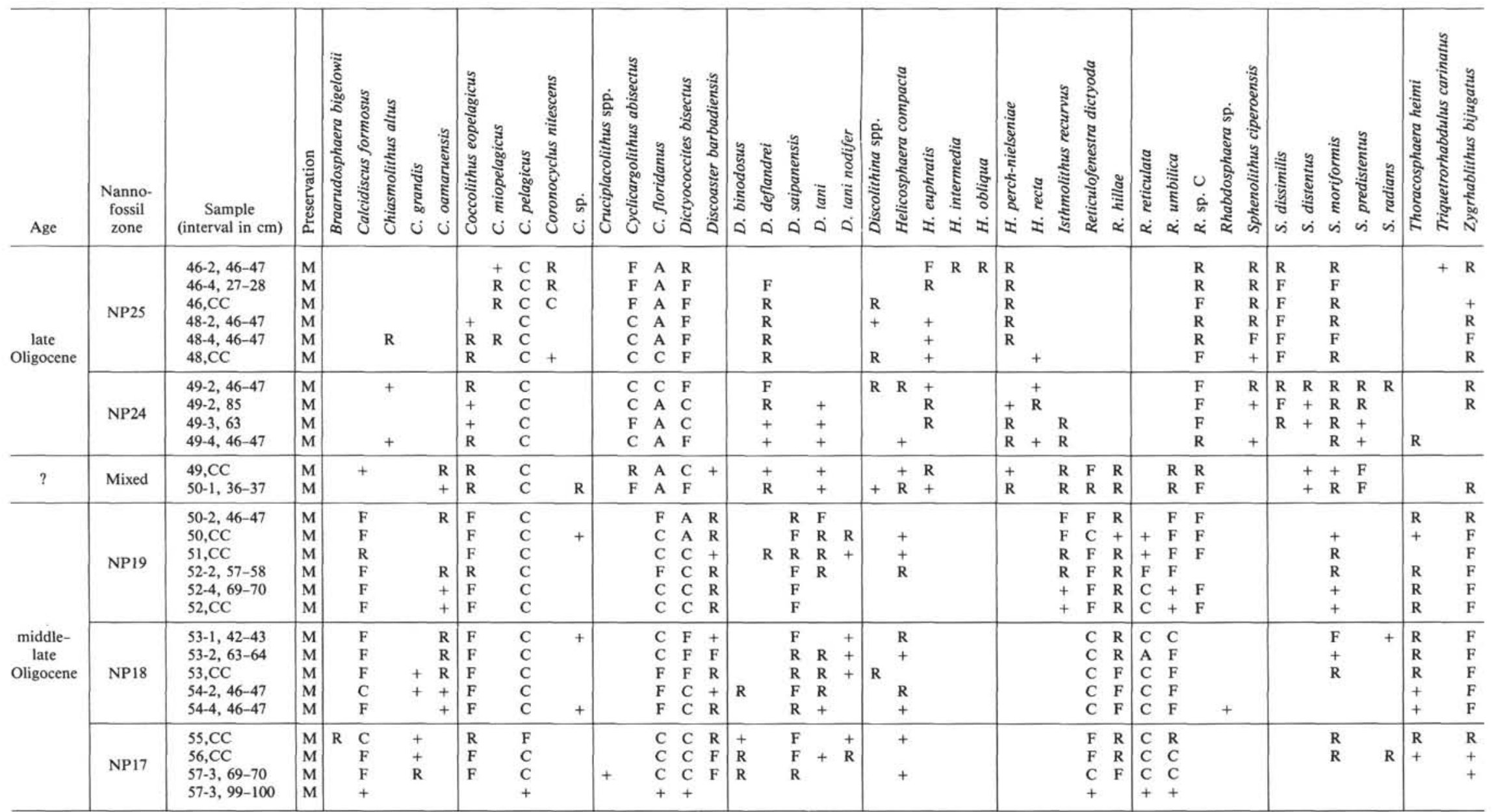

Note: For an explanation of symbols, see Table 3 and text. 
Table 9. Distribution of calcareous nannofossils, Hole 608A.

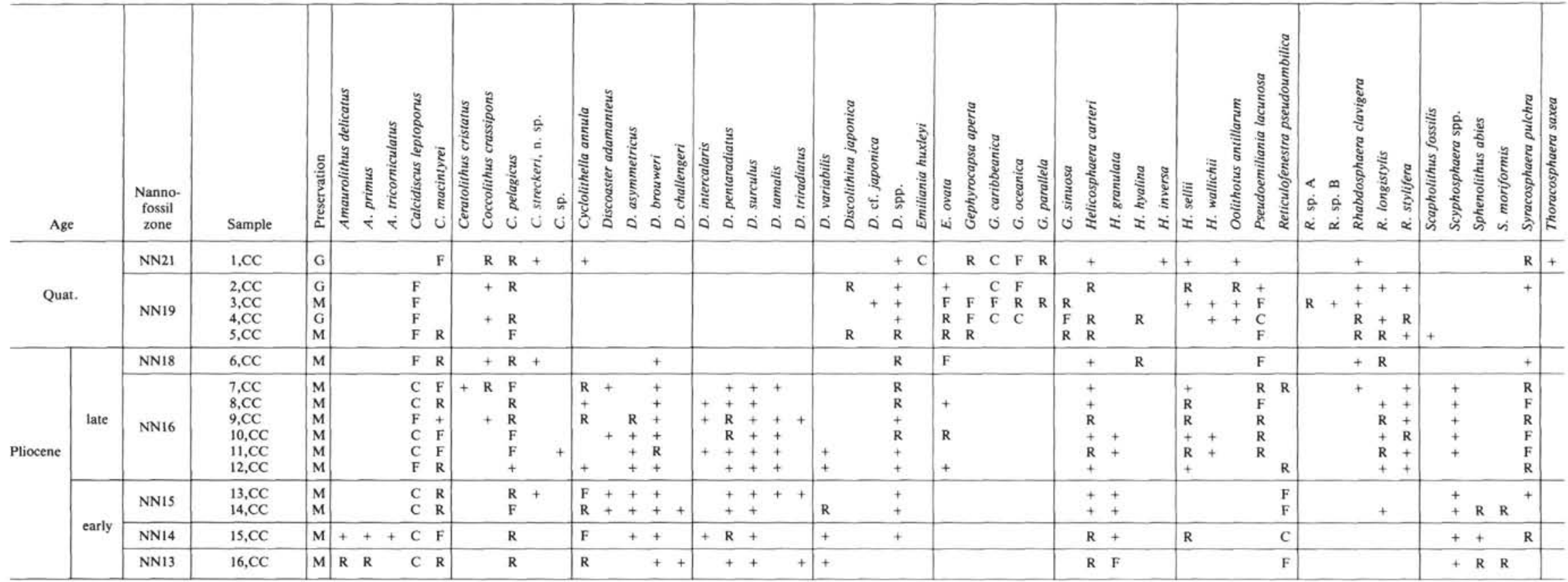

Note: For an explanation of the symbols, see Table 3 and text. 
Table 10. Distribution of calcareous nannofossils, Hole 609.

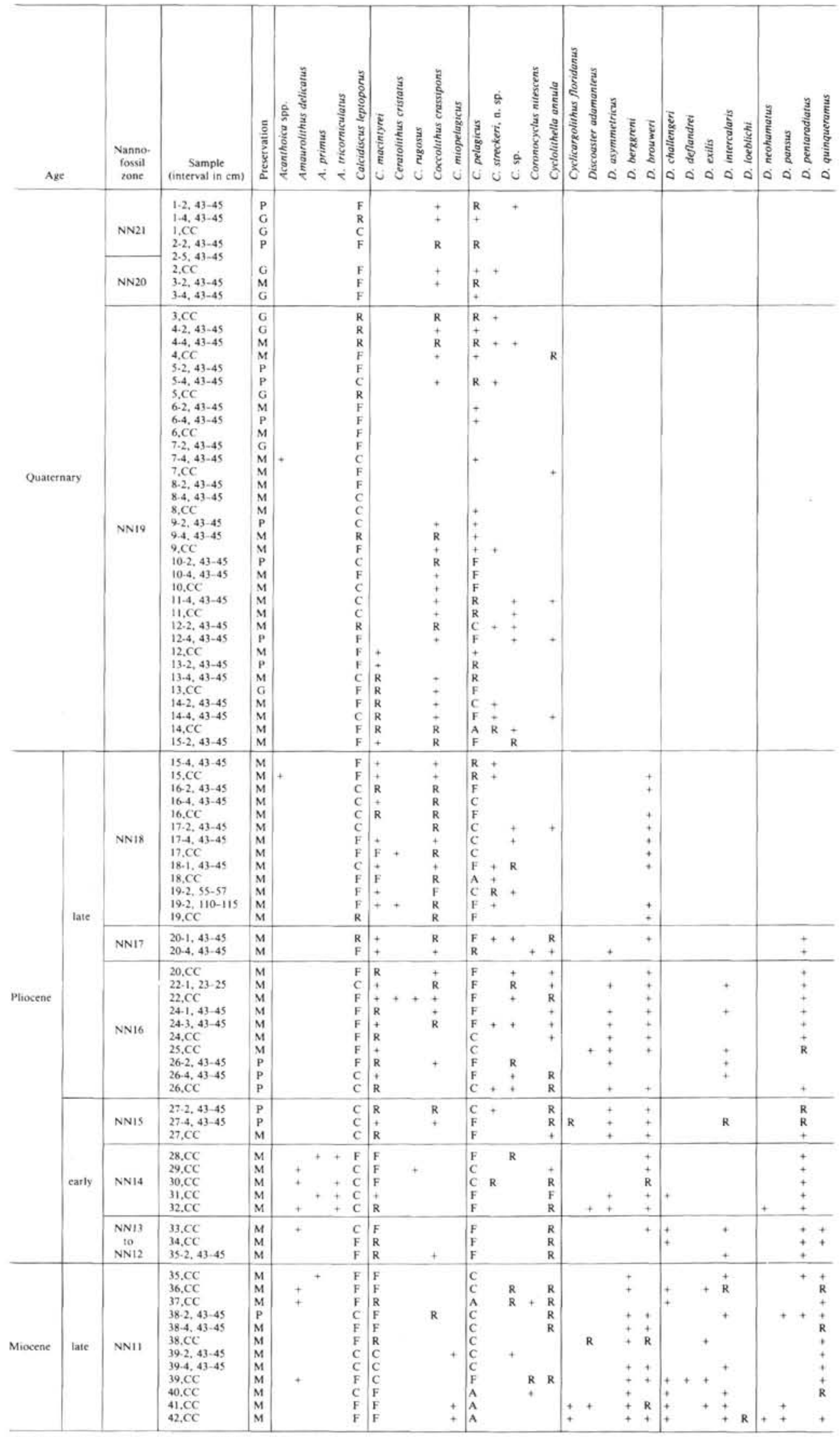

Note: For an explanation of symbols, see Table 3 and text, 
Table 10 (continued).

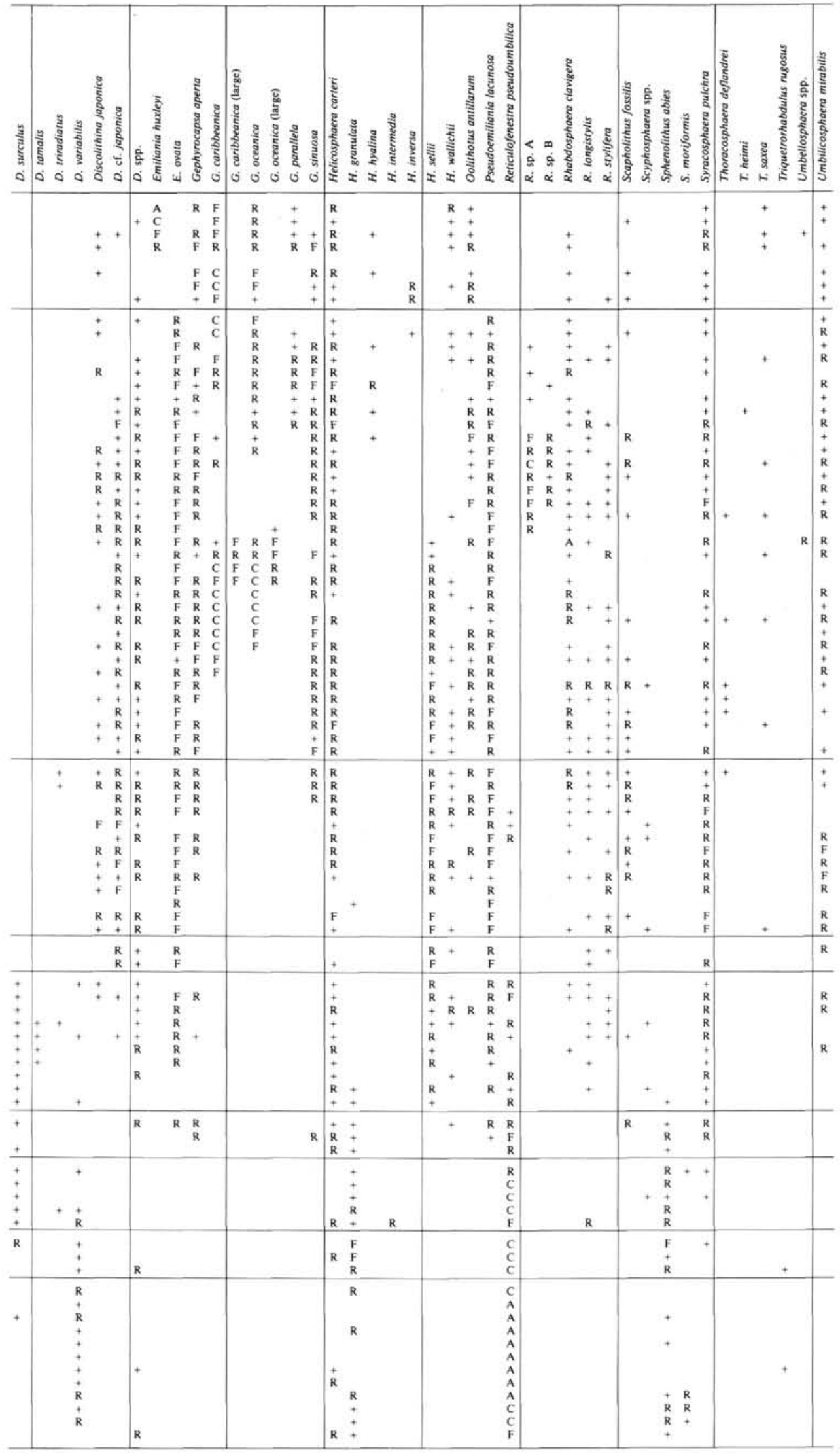


Table 11. Distribution of calcareous nannofossils, Hole 609A.

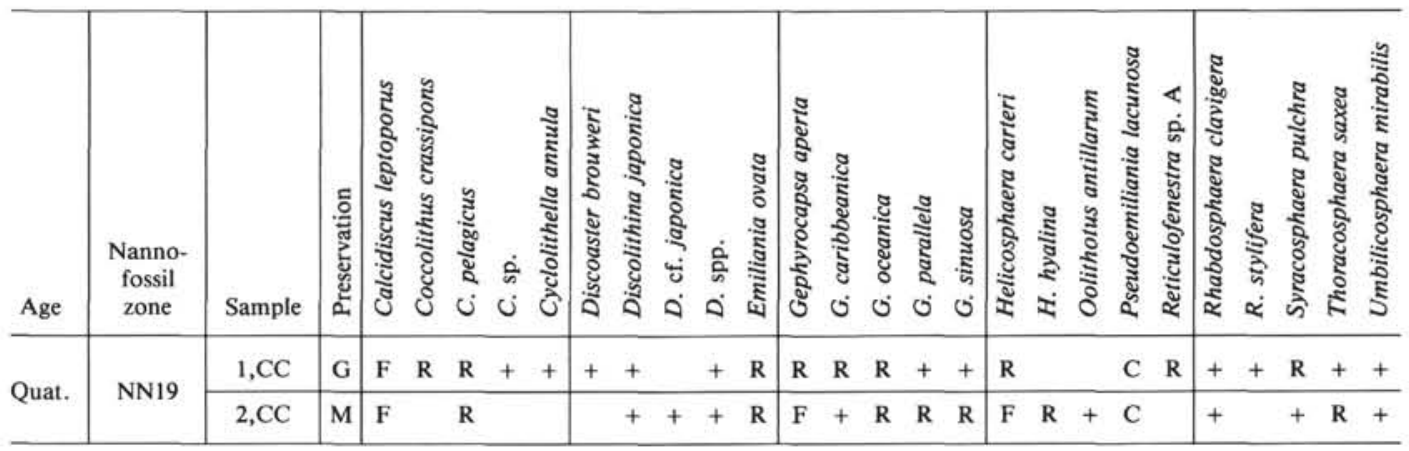

Note: For an explanation of symbols, see Table 3 and text.

\section{Site 610}

Six holes were drilled near the axis of the Feni sediment drift in Rockall Trough. Holes 610, 610A, 610B, and $610 \mathrm{C}$ were located on the crest of a sediment wave, and two offset holes-Holes 610D and 610E-were drilled in an adjacent trough, $0.7 \mathrm{~km}$ to the northwest and in water $28 \mathrm{~m}$ deeper.

All sediments yielded abundant calcareous nannofossils in various states of preservation and moderate diversity. An almost complete sequence of current-deposited sediments was identified, from late Pleistocene to Holocene NN21 (Emiliania huxleyi Zone) to early Miocene NN3 (Sphenolithus belemnos Zone). The calcareous nannoflora at this site contrasts sharply with the assemblages at previous sites, as indicated by the following criteria: discoasters are missing or extremely rare in the upper Pliocene sequences, and comparatively common Cretaceous reworked specimens and fairly abundant Oligocene-Eocene reworked specimens are found in the Quaternary and in the upper Miocene, respectively.

\section{Hole 610 (Table 14)}

The abundant occurrence of Emiliania huxleyi suggests that Sample 1,CC can be placed in the late Pleistocene to Holocene Emiliania huxleyi Zone (NN21). This sample also contains Gephyrocapsa caribbeanica, G. oceanica, Coccolithus pelagicus, Calcidiscus leptoporus, and Discolithina japonica. In addition to these species, Cretaceous specimens such as Watznaueria barnesae, Prediscosphaera cretacea, and Microrhabdulus decoratus are present. Samples 2,CC and 3,CC are placed in the Pleistocene Gephyrocapsa oceanica Zone (NN20) based on the abundant occurrences of Gephyrocapsa caribbeanica and G. oceanica and the absence of Pseudoemiliania lacunosa. In Sample 3,CC, the Cretaceous species Prediscosphaera cretacea, Arkhangelskiella cymbiformis, Eiffellithus turriseiffeli, and Watznaueria barnesae also occur. Samples 4,CC and 5,CC contain abundant Pseudoemiliania lacunosa and gephyrocapsid specimens and represent the Pleistocene Pseudoemiliania lacunosa Zone (NN19). Cretaceous reworked specimens such as Watznaueria barnesae and Eiffellithus turriseiffeli also occur in these samples.

Judging by the co-occurrence of Calcidiscus macintyrei and a few discoasters (such as Discoaster surculus,
D. brouweri, D. tamalis, and $D$. variabilis), and the absence of gephyrocapsids, Samples 6,CC through 9,CC are late Pliocene in age and are assigned to NN16 (Discoaster surculus Zone). Although Reticulofenestra pseudoumbilica is found throughout this zone, the number of specimens is limited. Core 10 was recovered after washing down 48 m; Sample 10,CC contains some Reticulofenestra pseudoumbilica together with Sphenolithus abies. The geological age of this sample, however, is not definite because no age-diagnostic species are present. The next lower sample, also obtained after washing down, is dominated by placoliths, particularly Coccolithus pelagicus, Calcidiscus leptoporus, and C. macintyrei. The presence of Discoaster quinqueramus places this sample within the late Miocene Discoaster quinqueramus Zone (NN11). Samples 12,CC and 13,CC contain no age-diagnostic species; the ages of these samples are therefore uncertain. The absence of five-rayed discoasters, however, suggests that these samples may be from below NN11. Sample 14,CC may belong to NN9 (Discoaster hamatus Zone), on the basis of the occurrence of Discoaster cf. hamatus. Coccolithus miopelagicus occurs continuously below Sample 15,CC, but the age of this sample is again uncertain. Cyclicargolithus floridanus is found continuously below Sample 16,CC. According to Bukry (1973), the LAD of this species coincides with the FAD of Discoaster kuglerii, which marks the boundary between NN7 and NN6. Therefore, Sample 16,CC is placed in the middle Miocene Discoaster exilis Zone (NN6). Samples 17,CC through 19,CC contain Sphenolithus heteromorphus and are placed in the Sphenolithus heteromorphus Zone (NN5). Samples 20,CC and 21,CC belong to the Helicosphaera ampliaperta Zone (NN4) on the basis of the presence of Helicosphaera ampliaperta. Sample 23,CC on down to the bottom of this hole belong to the early Miocene Sphenolithus belemnos Zone (NN3) based on the occurrence of Sphenolithus belemnos and the absence of Triquetrorhabdulus carinatus.

\section{Hole 610A (Table 15)}

The nannofossil assemblage in this hole is similar to that observed in Hole 610 .

Samples 1-2, 50-51 cm through 2-6, 70-71 cm are placed in the late Pleistocene to Holocene Emiliania huxleyi Zone (NN21), where Emiliania huxleyi, Gephyrocapsa caribbeanica, and $G$. oceanica occur together with 
several specimens reworked from the Cretaceous such as Watznaueria barnesae, W. britannica, Eiffellithus turriseiffeli, Arkhangelskiella cymbiformis, and Prediscosphaera cretacea. Samples 2,CC, 3-2, 50-51 cm, and 3-4, $50-51 \mathrm{~cm}$ are assigned to the Gephyrocapsa oceanica Zone (NN20) based on the coccolith assemblage without Emiliania huxleyi and Pseudoemiliania lacunosa. Cretaceous specimens such as Micula decussata, Arkhangelskiella cymbiformis, Watznaueria barnesae, and Prediscosphaera cretacea are also found in 2,CC. The occurrence of abundant Pseudoemiliania lacunosa places Samples 3-5, 50$51 \mathrm{~cm}$ on down to $11-3,50-51 \mathrm{~cm}$ in the early Pleistocene Pseudoemiliania lacunosa Zone (NN19). Reticulofenestra sp. A and $R$. sp. B are dominant in Samples $5, \mathrm{CC}$ through $7-4,50-51 \mathrm{~cm}$. Gephyrocapsa parallela occurs only in the upper half of the Quaternary sequence. Large-sized Gephyrocapsa are especially concentrated in Samples 7-4, 50-51 cm through 9-1, 50-51 cm. Helicosphaera sellii and Calcidiscus macintyrei occur below Samples $8-1,50-51 \mathrm{~cm}$ and $10-2,50-51 \mathrm{~cm}$, respectively. Samples $10-2,50-51 \mathrm{~cm}$ and $10-3,50-51 \mathrm{~cm}$ contain no $\mathrm{Ge}$ phyrocapsa oceanica and below Sample 10-4, 50-51 cm no gephyrocapsid specimen except Gephyrocapsa aperta and $G$. sinuosa occurs.

As discoasters are missing or extremely rare in the upper Pliocene in this hole, the Pliocene/Pleistocene boundary is not marked as clearly as it was at previous sites. However, a single specimen of Discoaster triradiatus is present in Sample 11-4, 50-51 cm and, therefore, the Pliocene/Pleistocene boundary is tentatively placed between Samples 11-3, 50-51 cm and 11-4, 50-51 cm in this hole. Below this boundary, the nannoflora changes progressively, with a gradual increase in the number of species and the number of specimens of discoasters. In the interval from Samples 11-4, 50-51 cm through 14-2, $50-51 \mathrm{~cm}$, the number of discoaster specimens is still limited; only Discoaster brouweri occurs. Thus these samples are assigned to the Discoaster brouweri Zone (NN18). Based on the co-occurrence of Discoaster brouweri and D. pentaradiatus, Samples 14-4, 50-51 cm and 14,CC are placed in the late Pliocene Discoaster pentaradiatus Zone (NN17). The occurrence of Discoaster pentaradiatus together with $D$. surculus indicates a late Pliocene age (NN16, Discoaster surculus Zone) for Samples 15-2, $50-51 \mathrm{~cm}$ through $20-2,50-51 \mathrm{~cm}$. In this hole Discoaster tamalis is rare and found in and below Sample 16-4, 50-51 cm. Comparatively abundant Reticulofenestra pseudoumbilica occurs throughout NN16. Its abundance, however, increases in Sample 20-4, 50-51 cm. Therefore samples from 20-4, 50-51 cm and on down to the bottom of this hole are assigned to early Pliocene NN15 (Reticulofenestra pseudoumbilica Zone). Sphenolithus abies occurs in Sample 21-2, 50-51 cm, well below the NN16/ NN15 boundary.

\section{Hole 610B (Table 16)}

Samples 1,CC and 2,CC contain abundant Emiliania huxleyi and are assigned to the late Pleistocene to Holocene Emiliania huxleyi Zone (NN21). Based on a coccolith assemblage without Emiliania huxleyi and Pseudoemiliania lacunosa, Sample $3, \mathrm{CC}$ is assigned to the
Gephyrocapsa oceanica Zone (NN20). The presence of abundant Pseudoemiliania lacunosa and the absence of discoasters may place Samples $4, C C$ to $14, C C$ in NN19 (Pseudoemiliania lacunosa Zone), but 11,CC to $14, \mathrm{CC}$ do not contain Gephyrocapsa caribbeanica and $G$. oceanica. Helicosphaera sellii and Calcidiscus macintyrei are found only below Samples $8, \mathrm{CC}$ and $11, \mathrm{CC}$, respectively. Comparatively large specimens of Gephyrocapsa are found in Sample 8,CC, and Reticulofenestra sp. A occurs also in Samples 6,CC and 7,CC. Cretaceous reworked specimens are present throughout the Quaternary.

Samples 15,CC and 16,CC contain Discoaster brouweri, $D$. pentaradiatus, and $D$. surculus and belong in the late Pliocene Discoaster surculus Zone (NN16). As at the previous holes of this site, discoasters are absent or extremely rare, and nannofossil Zones NN18 and NN17 cannot be recognized.

\section{Hole 610C (Table 17)}

The uppermost sample from Hole $610 \mathrm{C}$, Sample 1,CC, is assigned to the Emiliania huxleyi Zone (NN21). Sample 2,CC belongs to the Gephyrocapsa oceanica Zone (NN20) based on a coccolith assemblage without Emiliania huxleyi and Pseudoemiliania lacunosa. The presence of abundant Pseudoemiliania lacunosa and the absence of discoasters place Samples 3,CC and 4,CC in the Pseudoemiliania lacunosa Zone (NN19). One of these samples $(4, \mathrm{CC})$ has no gephyrocapsid specimen. A few specimens of Discoaster brouweri occur in Samples 5, CC and 6,CC, and these samples are assigned to NN18 (Discoaster brouweri Zone). The Pliocene/Pleistocene boundary is placed between Samples 4,CC and 5,CC. As at the previous holes, Cretaceous specimens are also present in this hole.

\section{Hole 610D (Table 18)}

Sample 1,CC is assigned to the late Pleistocene to Holocene Emiliania huxleyi Zone (NN21). A few Cretaceous reworked specimens also occur. The presence of gephyrocapsids and absence of Emiliania huxleyi and Pseudoemiliania lacunosa place Sample 2,CC in NN20 (Gephyrocapsa oceanica Zone). In this sample, Watznaueria barnesae, Micula decussata, Prediscosphaera cretacea, and Eiffellithus turriseiffeli are present. The occurrence of Pseudoemiliania lacunosa in Samples 3, CC to 5,CC indicates an early Pleistocene (NN19, Pseudoemiliania lacunosa Zone) age for these samples, which also contain Cretaceous specimens.

Samples 6,CC and 7,CC, which were obtained from the bottom of this hole after washing down, contain a calcareous nannoflora characterized by the occurrence of Discoaster loeblichi and the absence of Discoaster quinqueramus. Thus these two samples may be assigned to the late Miocene Discoaster calcaris Zone (NN10).

\section{Hole 610E (Table 19)}

In this hole, we detected five calcareous nannofossil datum levels. These datums are as follows in descending order: LAD of Discoaster quinqueramus (between Samples 1,CC and 2,CC), FAD of Amaurolithus spp. (be- 
Table 12. Distribution of calcareous nannofossils, Hole 609B.

\begin{tabular}{|c|c|c|c|c|c|c|c|c|c|c|c|c|c|c|c|c|c|c|c|c|c|c|c|}
\hline \multicolumn{2}{|c|}{ Age } & \multirow{2}{*}{$\begin{array}{c}\begin{array}{c}\text { Nanno- } \\
\text { fossil } \\
\text { zone }\end{array} \\
\text { NN21 }\end{array}$} & \multirow{2}{*}{$\begin{array}{l}\begin{array}{c}\text { Sample } \\
\text { (interval in } \mathrm{cm} \text { ) }\end{array} \\
1, \mathrm{CC} \\
2, \mathrm{CC}\end{array}$} & \multirow{2}{*}{ 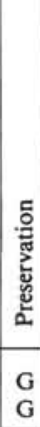 } & 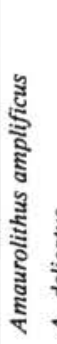 & \multicolumn{2}{|c|}{ 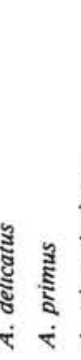 } & 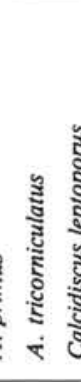 & \multicolumn{2}{|c|}{ 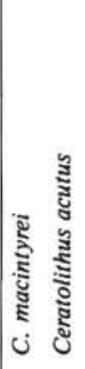 } & 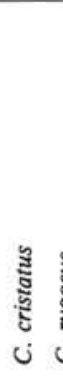 & 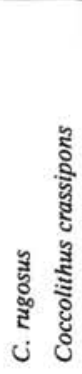 & 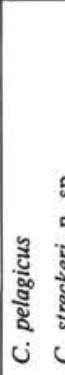 & \multicolumn{2}{|c|}{ 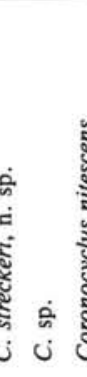 } & 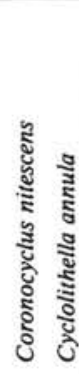 & 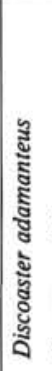 & 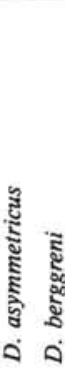 & \multicolumn{2}{|c|}{ 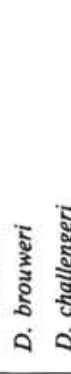 } & \multicolumn{3}{|c|}{ 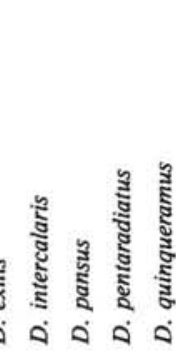 } \\
\hline \multirow{3}{*}{\multicolumn{2}{|c|}{ Quaternary }} & & & & & & & $\begin{array}{l}\mathrm{F} \\
\mathrm{C}\end{array}$ & & & & $\begin{array}{l}\mathrm{R} \\
\mathrm{R}\end{array}$ & $\begin{array}{l}+ \\
\mathrm{R}\end{array}$ & + & $\begin{array}{l}+ \\
+\end{array}$ & & & & & & & & \\
\hline & & $\mathrm{NN} 20$ & $3, \mathrm{CC}$ & G & & & & $\mathrm{R}$ & & & & & + & & & & & & & & & & \\
\hline & & NN19 & $\begin{array}{l}4, \mathrm{CC} \\
5, \mathrm{CC} \\
6, \mathrm{CC} \\
7, \mathrm{CC} \\
8, \mathrm{CC} \\
9, \mathrm{CC} \\
10, \mathrm{CC} \\
11, \mathrm{CC} \\
12, \mathrm{CC} \\
13, \mathrm{CC} \\
14, \mathrm{CC} \\
15, \mathrm{CC}\end{array}$ & $\begin{array}{l}\mathrm{G} \\
\mathrm{M} \\
\mathrm{M} \\
\mathrm{M} \\
\mathrm{P} \\
\mathrm{M} \\
\mathrm{G} \\
\mathrm{M} \\
\mathrm{M} \\
\mathrm{M} \\
\mathrm{M} \\
\mathrm{M}\end{array}$ & & & & $\begin{array}{l}\mathrm{F} \\
\mathrm{F} \\
\mathrm{F} \\
\mathrm{F} \\
\mathrm{C} \\
\mathrm{C} \\
\mathrm{C}\end{array}$ & $\begin{array}{l}\mathrm{R} \\
+ \\
\mathrm{R} \\
\mathrm{R}\end{array}$ & & 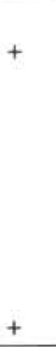 & $\begin{array}{l}+ \\
+ \\
+ \\
+ \\
+ \\
\text { R } \\
+\end{array}$ & $\begin{array}{l}+ \\
+ \\
+ \\
\\
+ \\
+ \\
\text { R } \\
\text { R } \\
\text { F } \\
\text { F } \\
\text { F } \\
\text { C }\end{array}$ & $\begin{array}{l} \\
\\
+ \\
+ \\
+ \\
+\end{array}$ & $\begin{array}{l}+ \\
+ \\
+\end{array}$ & & & & & & & & \\
\hline \multirow{4}{*}{ Pliocene } & & NN18 & $\begin{array}{l}16, \mathrm{CC} \\
17-1,120-121 \\
17, \mathrm{CC}\end{array}$ & $\begin{array}{l}\mathrm{M} \\
\mathrm{M} \\
\mathrm{G}\end{array}$ & & & & $\begin{array}{l}\mathbf{F} \\
\mathbf{R} \\
\mathrm{C}\end{array}$ & $\begin{array}{l}\mathrm{R} \\
\mathrm{R} \\
\mathrm{R}\end{array}$ & & & $\begin{array}{l}+ \\
\mathrm{R} \\
\mathrm{R}\end{array}$ & $\begin{array}{l}\mathrm{R} \\
\mathrm{F} \\
\mathrm{F}\end{array}$ & & + & + & & & $\begin{array}{l}+ \\
+ \\
+\end{array}$ & $\begin{array}{l}+ \\
+ \\
+\end{array}$ & & & \\
\hline & late & NN16 & $\begin{array}{l}19, \mathrm{CC} \\
20, \mathrm{CC} \\
21, \mathrm{CC} \\
22, \mathrm{CC} \\
23, \mathrm{CC} \\
24, \mathrm{CC} \\
25, \mathrm{CC} \\
26, \mathrm{CC} \\
27, \mathrm{CC}\end{array}$ & $\begin{array}{l}\text { G } \\
\text { G } \\
\text { G } \\
\text { G } \\
\text { G } \\
\text { G } \\
\text { G } \\
\text { M } \\
\text { M }\end{array}$ & & & & $\begin{array}{l}\text { R } \\
\text { F } \\
\text { F } \\
\text { R } \\
\text { R } \\
\text { F } \\
\text { C } \\
\text { F } \\
\text { F }\end{array}$ & $\begin{array}{l}R \\
R \\
F \\
+ \\
R \\
R \\
F\end{array}$ & & & $\begin{array}{l}+ \\
+ \\
+ \\
+ \\
+\end{array}$ & $\begin{array}{l}F \\
F \\
R \\
R \\
F \\
F \\
C \\
C \\
F\end{array}$ & $\begin{array}{l}+ \\
+ \\
+ \\
+\end{array}$ & + & $\begin{array}{r}+ \\
+ \\
\mathbf{R} \\
+ \\
+ \\
+ \\
+ \\
+ \\
+ \\
+\end{array}$ & + & $\begin{array}{l}+ \\
+ \\
+ \\
+ \\
+ \\
+ \\
+ \\
+ \\
+\end{array}$ & $\begin{array}{l}+ \\
+ \\
+ \\
+ \\
+ \\
+ \\
\text { R } \\
+ \\
+\end{array}$ & 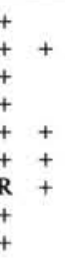 & & $\mathbf{R}$ & $\begin{array}{l}+ \\
+ \\
+ \\
+ \\
+ \\
+ \\
+ \\
+\end{array}$ \\
\hline & \multirow[t]{2}{*}{ early } & $\begin{array}{l}\text { NN15 to } \\
\text { NN14 }\end{array}$ & $\begin{array}{l}28, \mathrm{CC} \\
29, \mathrm{CC} \\
30, \mathrm{CC} \\
31, \mathrm{CC} \\
32, \mathrm{CC}\end{array}$ & $\begin{array}{l}\mathrm{P} \\
\mathrm{P} \\
\mathrm{M} \\
\mathrm{M} \\
\mathrm{M}\end{array}$ & + & & ++ & $\begin{array}{l}\text { C } \\
\text { F } \\
\text { C } \\
\text { C } \\
\text { C }\end{array}$ & $\begin{array}{l}\mathrm{R} \\
\mathrm{R} \\
\mathrm{R} \\
\mathrm{R} \\
\mathrm{F}\end{array}$ & & & + & $\begin{array}{l}\mathrm{C} \\
\mathrm{F} \\
\mathrm{C} \\
\mathrm{C} \\
\mathrm{C}\end{array}$ & + & $\begin{array}{l}+ \\
+ \\
+\end{array}$ & $\begin{array}{r}+ \\
+\quad+ \\
\mathbf{F} \\
+ \\
+\end{array}$ & & $\begin{array}{l}+ \\
+ \\
+\end{array}$ & $\begin{array}{l}R \\
+\end{array}$ & & & $\begin{array}{l}+ \\
+ \\
+ \\
++\end{array}$ & $\begin{array}{l}+ \\
+ \\
+ \\
+ \\
+\end{array}$ \\
\hline & & $\begin{array}{l}\text { NN13 to } \\
\text { NN12 }\end{array}$ & $\begin{array}{l}33, \mathrm{CC} \\
34, \mathrm{CC}\end{array}$ & $\begin{array}{l}\mathrm{M} \\
\mathrm{M}\end{array}$ & & & & $\begin{array}{l}\mathrm{C} \\
\mathrm{C}\end{array}$ & $\mathbf{R}$ & & & & $\begin{array}{l}\text { C } \\
\text { A }\end{array}$ & & + & $\begin{array}{r}+\quad R \\
+\quad R \\
\end{array}$ & & + & + & + & + & $\begin{array}{l}+ \\
+\end{array}$ & $\begin{array}{l}+ \\
\mathrm{R}\end{array}$ \\
\hline Mio. & late & NN11 & $\begin{array}{l}35, \mathrm{CC} \\
36, \mathrm{CC} \\
37, \mathrm{CC} \\
38, \mathrm{CC}\end{array}$ & $\begin{array}{l}\mathrm{M} \\
\mathrm{M} \\
\mathrm{M} \\
\mathrm{M}\end{array}$ & & + & & $\begin{array}{l}\text { F } \\
\text { C } \\
\text { C } \\
\text { C }\end{array}$ & $\begin{array}{l}\mathbf{R} \\
\mathbf{F}\end{array}$ & & & & $\begin{array}{l}C \\
C \\
C \\
C\end{array}$ & & & $\begin{array}{l}+ \\
+\end{array}$ & & $\begin{array}{l}+ \\
+ \\
+\end{array}$ & $\begin{array}{l}+ \\
+ \\
+\end{array}$ & $\begin{array}{l}+ \\
+ \\
+ \\
+ \\
+\end{array}$ & $\begin{array}{l}+ \\
+ \\
+\end{array}$ & $\begin{array}{l}+ \\
+ \\
+ \\
+\end{array}$ & $\begin{array}{l}+\quad+ \\
+ \\
+\quad \mathrm{R} \\
+\quad+\end{array}$ \\
\hline
\end{tabular}

Note: For an explanation of symbols, see Table 3 and text.

tween Samples 3,CC and 4,CC), FAD of Discoaster surculus (between Samples 5,CC and 6,CC), LAD of Discoaster neohamatus (between Samples 5,CC and 6,CC), and FAD of Discoaster berggrenii and/or D. quinqueramus (between Samples 6,CC and 7,CC). According to these data, Sample 1,CC, Samples 2,CC through 6,CC, and Sample 7,CC are placed in NN12 (Amaurolithus tricorniculatus Zone), NN11 (Discoaster quinqueramus Zone), and NN10 (Discoaster calcaris Zone), respectively.

\section{Site 611}

Six holes were drilled on the lower southeastern flank of the Gardar Drift. Four were drilled on the broad crest of a sediment wave at $3201 \mathrm{~m}$ water depth and the remaining two holes were located in an adjacent trough half a nautical mile to the southeast and in water $29 \mathrm{~m}$ deeper.

Samples examined contain middle Miocene to Holocene calcareous nannofossils. The state of preservation is generally good to moderate, and the species diversity is moderate.

\section{Hole 611 (Table 20)}

The calcareous nannoflora in Samples 1,CC through $4-4,50-51 \mathrm{~cm}$ is characterized by an abundance of poorly preserved small and fragile specimens. Preservation of coccoliths in Sample 4-4, $50-51 \mathrm{~cm}$ is especially poor:

The uppermost two samples from this hole, Samples 1,CC and 2-1, 60-61 cm, are correlated with the Emiliania huxleyi Zone (NN21). These samples also contain 


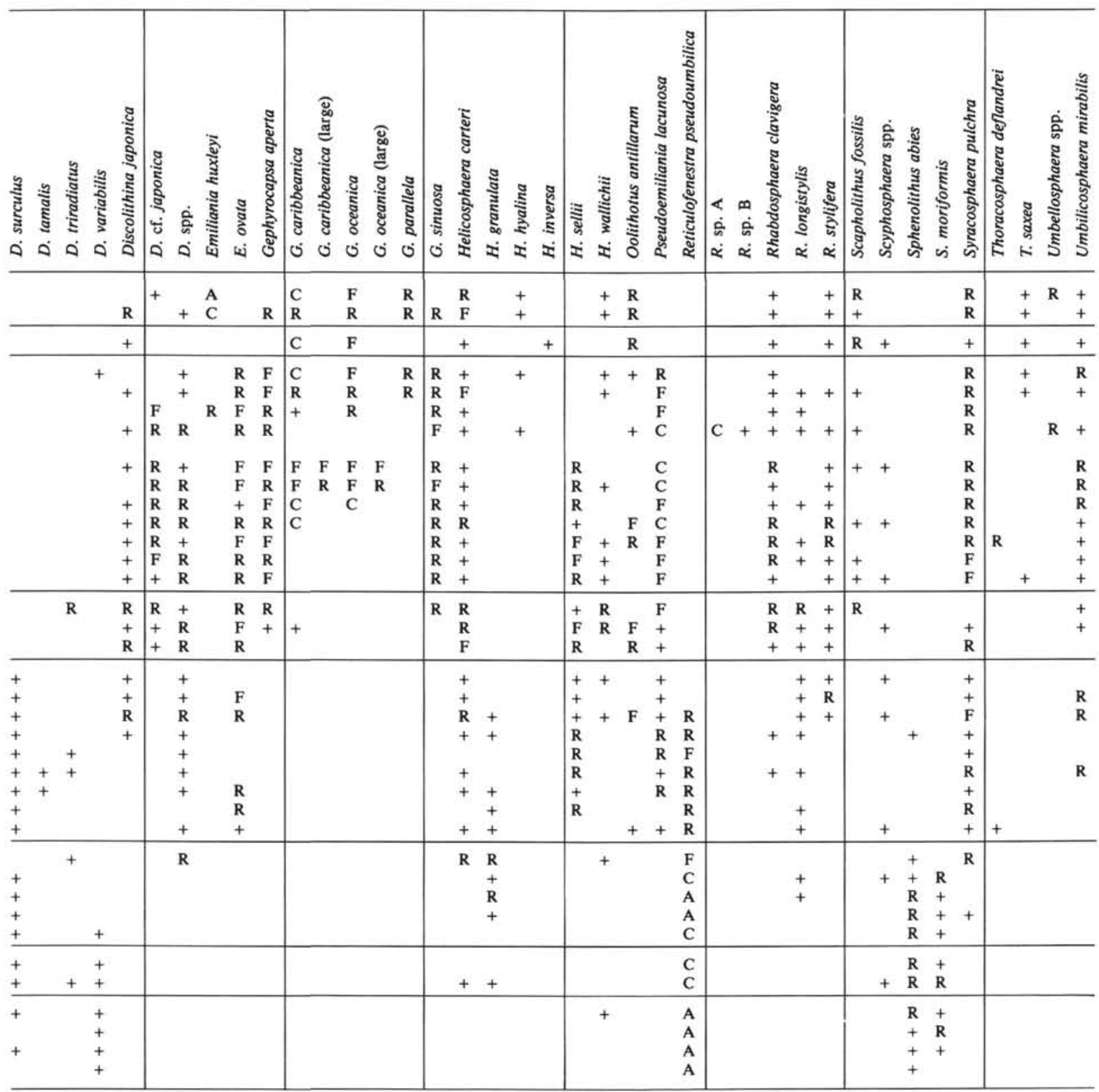

Cretaceous reworked specimens such as Watznaueria barnesae, Arkhangelskiella cymbiformis, and Eiffellithus turriseiffeli. Sample 2-3, 50-51 cm is placed in NN20 (Gephyrocapsa oceanica Zone), because Emiliania huxleyi and Pseudoemiliania lacunosa were not found. The occurrence of Pseudoemiliania lacunosa and the absence of discoasters suggest that Samples 2-4, 50-51 cm through 9-2, 50-51 cm can be correlated with the early Pleistocene Pseudoemiliania lacunosa Zone (NN19). In this zone, Samples $4-4,50-51 \mathrm{~cm}$ through 5,CC contain fairly abundant Reticulofenestra pseudoumbilica-like specimens (Reticulofenestra sp. A. and $R$. sp. B), which were also recognized in previous holes. Gephyrocapsa parallela occurs nearly continuously from the top of this hole on down to Sample 4-5, 50-51 cm. The assemblages of Samples 6-2, 50-51 cm through 6,CC are characterized by the fairly abundant occurrences of large Gephyrocapsa specimens. The last appearance datums (LADs) of Helicosphaera sellii and Calcidiscus macintyrei were detected in this hole $(6-3,50-51 \mathrm{~cm} / 6-4,50-51 \mathrm{~cm}$, and $7, \mathrm{CC} / 8-1,50-51 \mathrm{~cm})$. The first appearance datums (FADs) of Gephyrocapsa oceanica and G. caribbeanica are present between Samples 7,CC and 8-1, 50-51 cm, and $8-4,50-51 \mathrm{~cm}$ and $8-5,50-51 \mathrm{~cm}$. The Cretaceous specimens are similar to those found in the upper part of this zone. Helicosphaera inversa was not found.

The Pliocene/Pleistocene boundary is not clearly detected in this hole because of the scarcity of discoasters. Sample 9-3, 50-51 cm contains Discoaster brouweri together with $D$. triradiatus, and thus the Tertiary/Quaternary boundary may occur between Samples 9-2, 50$51 \mathrm{~cm}$ and $9-3,50-51 \mathrm{~cm}$. Samples $9-3,50-51 \mathrm{~cm}$ to 
Table 13. Distribution of calcareous nannofossils, Hole $609 \mathrm{C}$.

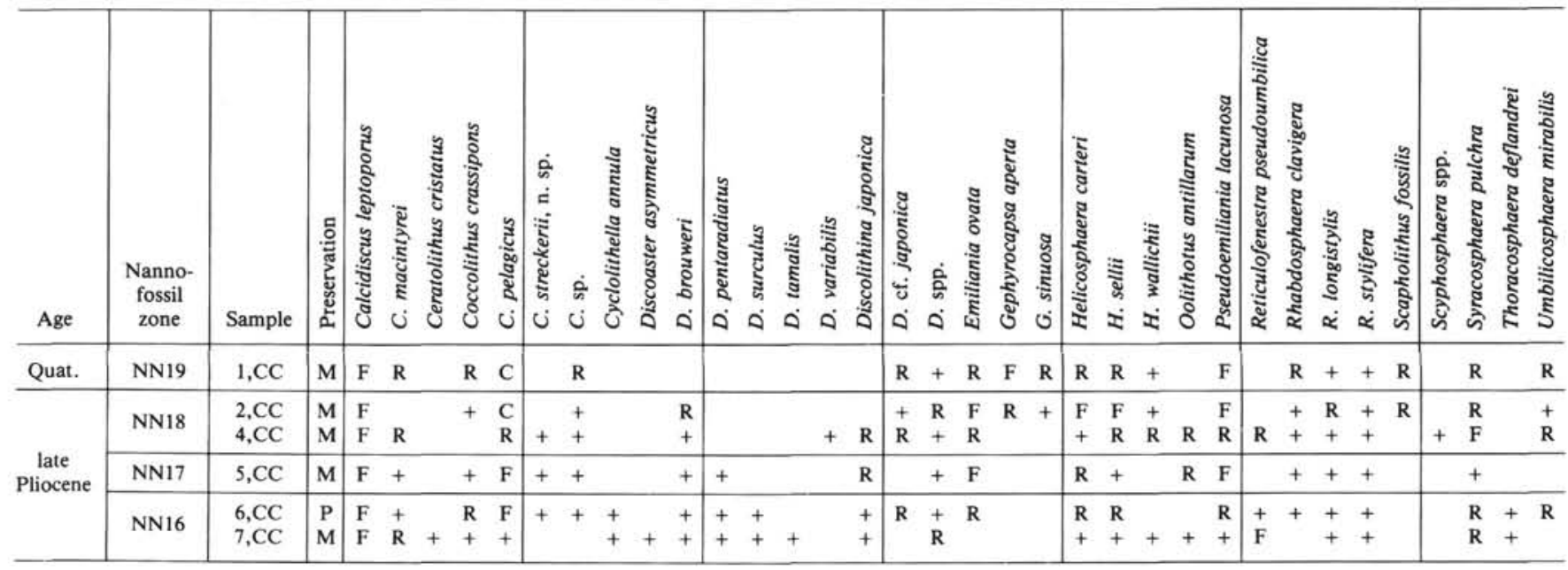

Note: See Table 3 and text for explanation of symbols.

12, CC are assigned to NN18 (Discoaster brouweri Zone). The co-occurrence of Discoaster brouweri and D. pentaradiatus in Samples 13-1, 50-51 cm and 13-2, 50-51 $\mathrm{cm}$ places this interval in NN17 (Discoaster pentaradiatus Zone). Below this, discoasterid assemblages gradually change, with an increase in the number of species and the number of specimens. Samples from 13-3, 50$51 \mathrm{~cm}$ on down to the bottom of this hole contain Discoaster surculus and are assigned to the late Pliocene Discoaster surculus Zone (NN16). Reticulofenestra pseudoumbilica occurs sporadically throughout Zones NN18, NN17, and NN16.

\section{Hole 611A (Table 21)}

Samples from this hole contain abundant calcareous nannofossils, except Sample 5,CC. Sample 1,CC may represent the Emiliania huxleyi Zone (NN21). The occurrence of Pseudoemiliania lacunosa and the absence of discoasters suggest that Samples 2,CC through 10,CC can be correlated with NN19 (Pseudoemiliania lacunosa Zone). Samples 4,CC and 5,CC contain fairly abundant Reticulofenestra sp. A. Cretaceous specimens are found in the upper part of this zone.

Discoasters are extremely rare, and it is therefore very difficult to detect the LAD of Discoaster brouweri. The Pliocene/Pleistocene boundary is placed between Samples 10,CC and 11,CC. Discoaster brouweri occurs in Sample $11, C C, D$. pentaradiatus in $12, C C$, and $D$. surculus in 13,CC; therefore Samples 11,CC, 12,CC, and 13, CC are assigned to Zones NN18, NN17, and NN16, respectively.

\section{Hole 611B (Table 22)}

Only one of the core-catcher samples examined contains Quaternary calcareous nannofossils. This sample contains no Emiliania huxleyi and Pseudoemiliania lacunosa, and belongs in NN20 (Gephyrocapsa oceanica Zone). The preservation of coccoliths is poor.

\section{Hole 611C (Table 23)}

Abundant occurrences of Emiliania huxleyi suggest that Samples 1,CC and 2, CC can be correlated with the late Pleistocene to Holocene Emiliania huxleyi Zone (NN21). A few specimens of Eiffellithus turriseiffeli and Watznaueria barnesae in Sample 2,CC are reworked from Cretaceous outcrops. Sample 3, CC belongs to NN20 ( $\mathrm{Ge}$ phyrocapsa oceanica Zone), based on the absence of Emiliania huxleyi and Pseudoemiliania lacunosa. The next five samples down (Samples 4,CC through 9,CC) contain abundant Pseudoemiliania lacunosa and are placed in the early Pleistocene Pseudoemiliania lacunosa Zone (NN19). Several Cretaceous reworked specimens are also found in this zone (in Sample 5,CC). Sample 6,CC contains abundant Reticulofenestra sp. A and $R$. sp. B. Sample 10,CC is barren of calcareous nannofossils, except for a few undiagnostic specimens.

As in previous holes, discoasters are missing or extremely rare in the upper Pliocene. As a result, the Pliocene/Pleistocene boundary cannot be identified precisely. Sample 11,CC, however, does contain Discoaster brouweri and $D$. triradiatus, and the Pliocene/Pleistocene boundary is placed between Samples 9, CC and 11,CC. Samples $11, \mathrm{CC}$ through $13, \mathrm{CC}$ are assigned to NN18 (Discoaster brouweri Zone). Judging by the co-occurrence of Discoaster brouweri and $D$. pentaradiatus, Sample $14, \mathrm{CC}$ is placed in NN17 (Discoaster pentaradiatus Zone). Below this, discoasterid assemblages gradually change and Discoaster surculus is found together with Discoaster variabilis, D. asymmetricus, and D. tamalis. Reticulofenestra pseudoumbilica is relatively abundant, but the abundance of this species increases in Sample 22, CC. Consequently, the boundary between NN16 (Discoaster surculus Zone) and NN15 (Reticulofenestra pseudoumbilica Zone) is placed between Samples 22-4, 50$51 \mathrm{~cm}$ and 22,CC. Because Discoaster asymmetricus is not found below Sample 26-2, 50-51 cm, the NN14 (Discoaster asymmetricus Zone)/NN13 (Ceratolithus rugosus Zone) boundary is placed between Cores 24 and 26 . 
Table 14. Distribution of calcareous nannofossils, Hole 610.

\begin{tabular}{|c|c|c|c|c|c|c|c|c|c|c|c|c|c|c|c|c|c|c|c|c|c|}
\hline $\mathrm{Age}$ & $\begin{array}{l}\text { Nanno- } \\
\text { fossil } \\
\text { zone }\end{array}$ & Sample & & 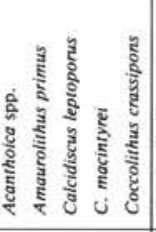 & 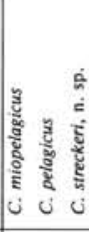 & 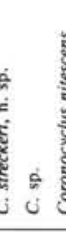 & 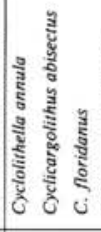 & 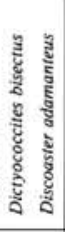 & 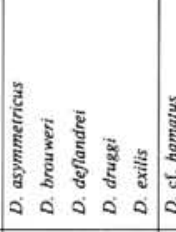 & 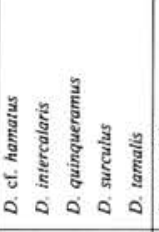 & 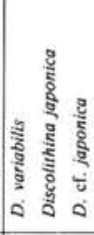 & 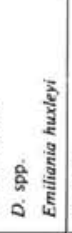 & 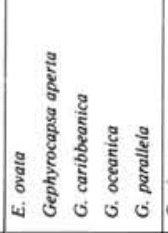 & 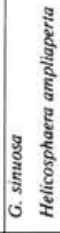 & 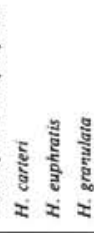 & 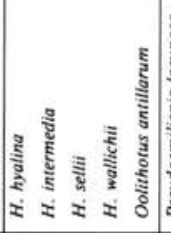 & 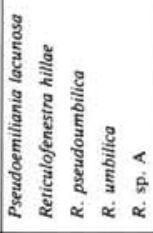 & 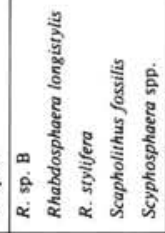 & 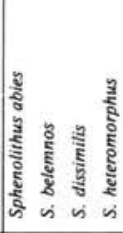 & 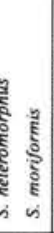 & 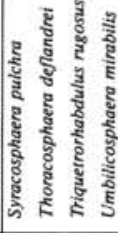 \\
\hline \multirow{3}{*}{ Qualetnary } & NN21 & I.CC & $\mathrm{G}$ & $\begin{array}{ll}F & R \\
\end{array}$ & $R$ & & & & & & + & $\mathrm{c}$ & $R \quad F \quad R$ & $R$ & + & + & & + & & & $R$ \\
\hline & $\mathrm{NN} 20$ & $\begin{array}{l}2, \mathrm{CC} \\
3, \mathrm{CC}\end{array}$ & $\begin{array}{l}\mathrm{M} \\
\mathrm{M}\end{array}$ & $\begin{array}{rrr} & F & R \\
+ & F & + \\
\end{array}$ & ++ & & & & & & & + & $\begin{array}{|lll|}\mathrm{F} & \mathrm{C} & \mathrm{C} \\
\mathrm{F} & \mathrm{F} & \mathrm{F} \\
\end{array}$ & $\begin{array}{l}\mathrm{R} \\
\mathrm{R}\end{array}$ & \pm & \pm+ & & + & & & $\begin{array}{l}\mathrm{R} \\
\mathrm{F} \\
\end{array}$ \\
\hline & NN19 & $\begin{array}{l}4, \mathrm{CC} \\
5, \mathrm{CC} \\
\end{array}$ & \begin{tabular}{l|l}
$G$ \\
$G$ \\
\end{tabular} & $\begin{array}{lll}+ & \mathbf{R} & + \\
+ & \mathrm{F} & + \\
\end{array}$ & + & & & & & & & $\stackrel{+}{R}$ & 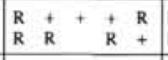 & $\begin{array}{l}R \\
R \\
\end{array}$ & $\begin{array}{l}R \\
R \\
R\end{array}$ & \begin{tabular}{l|l}
$\mathbf{R}$ & \\
$\mathbf{R}$ & \\
\end{tabular} & $\begin{array}{l}\mathrm{F} \\
\mathrm{F}\end{array}$ & ++++ & & & \begin{tabular}{|l}
$\mathrm{F}$ \\
$\mathrm{R}$
\end{tabular} \\
\hline $\begin{array}{l}\text { late } \\
\text { Pliocene }\end{array}$ & NN16 & $\begin{array}{l}6, \mathrm{CC} \\
7, \mathrm{CC} \\
8, \mathrm{CC} \\
9, \mathrm{CC} \\
\end{array}$ & \begin{tabular}{c|}
$\mathrm{M}$ \\
$\mathrm{M}$ \\
$\mathrm{M}$ \\
$\mathrm{G}$
\end{tabular} & 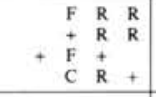 & $\begin{array}{l}\mathrm{C} \\
\mathrm{C}+ \\
\mathrm{F} \\
\mathrm{C}+\end{array}$ & + & $\begin{array}{l}R \\
+ \\
+ \\
+\end{array}$ & + & + & \pm+ & + & \pm & & & $\begin{array}{ll}+ & \mathbf{R} \\
+ & + \\
+ & \mathbf{R}\end{array}$ & + & $\begin{array}{ll}\mathbf{R} & \\
\mathbf{R} & + \\
+ & + \\
\mathbf{R} & +\end{array}$ & $\begin{array}{r}+ \\
+ \\
+ \\
+\end{array}$ & & & $\begin{array}{l}+ \\
+ \\
+ \\
R \\
+ \\
+ \\
+\end{array}$ \\
\hline \multirow{10}{*}{ Miocene } & $?$ & $10, \mathrm{CC}$ & $\mathrm{G}$ & c c & c. & & + & & & $+\quad+$ & + & & & & + & & $F$ & & + & + & \\
\hline & $\mathrm{NN1I}$ & $11, \mathrm{CC}$ & M & C F R & A $R$ & $R+$ & + & + & & + & + & & & & & & + & & + & + & \\
\hline & $?$ & $\begin{array}{l}12, \mathrm{CC} \\
13, \mathrm{CC} \\
\end{array}$ & $\begin{array}{c}\mathrm{M} \\
\mathrm{P} \\
\end{array}$ & $\begin{array}{l}\mathrm{F}+\mathrm{R} \\
\mathrm{F}+\mathrm{R}\end{array}$ & A & & $\dot{R}$ & & ++ & + & + & & & & $\begin{array}{ll}\mathrm{R} & + \\
+ & \mathrm{R} \\
\end{array}$ & & $\begin{array}{l}F \\
R\end{array}$ & & $\begin{array}{ll}R \\
F\end{array}$ & + & $R^{+}+$ \\
\hline & NN9? & $14, \mathrm{CC}$ & $\mathrm{M}$ & $\mathrm{F} F$ & c & & & & ++ & + & R & & & & + & & c & & F & $\mathrm{R}$ & + \\
\hline & $?$ & $15, \mathrm{CC}$ & M & $\mathbf{R}+$ & $+\mathrm{C}$ & + & ++ & + & + & & + & & & & $+\quad+$ & & A & & + & + & + \\
\hline & NN6 & $16, \mathrm{CC}$ & $\mathrm{P}$ & & $+\mathrm{C}$ & & +++ & & + & & & & & & + & & $+\mathrm{C}+$ & & + & + & + \\
\hline & NNS & $17, \mathrm{CC}$ & $\mathrm{P}$ & $R \quad R$ & $+\mathrm{A}$ & & + & & + & & R & & & & $\mathbf{F}+$ & & c & & & ++ & \\
\hline & $\begin{array}{l}\text { NNS } \\
\text { NNS }\end{array}$ & $\begin{array}{l}18, \mathrm{CC} \\
19, \mathrm{CC}\end{array}$ & $\begin{array}{l}\mathrm{M} \\
\mathrm{M} \\
\end{array}$ & $R^{R}$ & $\begin{array}{ll}\mathrm{F} & \mathrm{A} \\
\mathrm{R} & \mathrm{A} \\
\end{array}$ & & $\begin{array}{r}R R \\
+\quad F \\
\end{array}$ & & \pm+ & & $R$ & + & & & ${ }_{\mathrm{R}}^{\mathrm{F}} \mathrm{R}^{\mathrm{R}} \mathrm{F}$ & + & $\begin{array}{l}\mathrm{F} \\
\mathrm{C}\end{array}$ & & $\begin{array}{l}R \\
R \\
R\end{array}$ & $\begin{array}{r}+\quad F \\
F \\
F\end{array}$ & \\
\hline & $\mathrm{NN} 4$ & $\begin{array}{l}20, \mathrm{CC} \\
21, \mathrm{CC}\end{array}$ & $\begin{array}{c}\mathrm{M} \\
\mathrm{P}\end{array}$ & ${ }_{R}^{R}+$ & $\begin{array}{ll}+ & A \\
R & A \\
\end{array}$ & & $\begin{array}{r}++\begin{array}{l}F \\
+\end{array} \\
\end{array}$ & & $\begin{array}{l}\mathrm{R} \\
\mathrm{R}\end{array}$ & & + & & & & $\begin{array}{ll}\mathrm{R} & \mathrm{F} \\
\mathrm{F} & \\
\end{array}$ & & $\stackrel{A}{C}+$ & & $\begin{array}{l}\mathrm{R} \\
\mathrm{F} \\
\end{array}$ & \begin{tabular}{ll|}
$R$ & $R$ \\
$F$ & $R$ \\
\end{tabular} & + \\
\hline & NN3 & $\begin{array}{l}22, \mathrm{CC} \\
23, \mathrm{CC} \\
24, \mathrm{CC} \\
25, \mathrm{CC} \\
26, \mathrm{CC} \\
27, \mathrm{CC}\end{array}$ & \begin{tabular}{|l|}
$\mathrm{P}$ \\
$\mathrm{p}$ \\
$\mathrm{p}$ \\
$\mathrm{p}$ \\
$\mathrm{P}$ \\
$\mathrm{P}$
\end{tabular} & $\begin{array}{l}\mathrm{R} \\
\mathrm{R}+\end{array}$ & 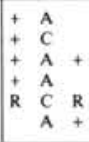 & $\begin{array}{l}+ \\
+ \\
+ \\
+ \\
+\end{array}$ & $\begin{array}{r}\mathbf{R} \\
\mathrm{F} \\
+ \\
+ \\
+ \\
+ \\
\mathbf{R}\end{array}$ & & $\begin{array}{l}++ \\
F+ \\
F+ \\
F+ \\
\mathrm{R}_{+}^{+} \\
+\end{array}$ & & & + & & + & $\begin{array}{l}\mathrm{R} \\
+ \\
+\end{array}$ & R & $\begin{array}{l}\mathrm{A} \\
\hat{A} \\
\hat{A} \\
\hat{A}\end{array}$ & & $\begin{aligned} & +F+ \\
& + \\
& + \\
R & + \\
R & + \\
& +\end{aligned}$ & $\begin{array}{r}\mathrm{F} \\
+\mathrm{F} \\
\mathrm{F} \\
\mathrm{R} \\
+ \\
+\end{array}$ & + \\
\hline
\end{tabular}

Note: See Table 3 and text for an explanation of symbols. 
Table 15. Distribution of calcareous nannofossils, Hole 610A.

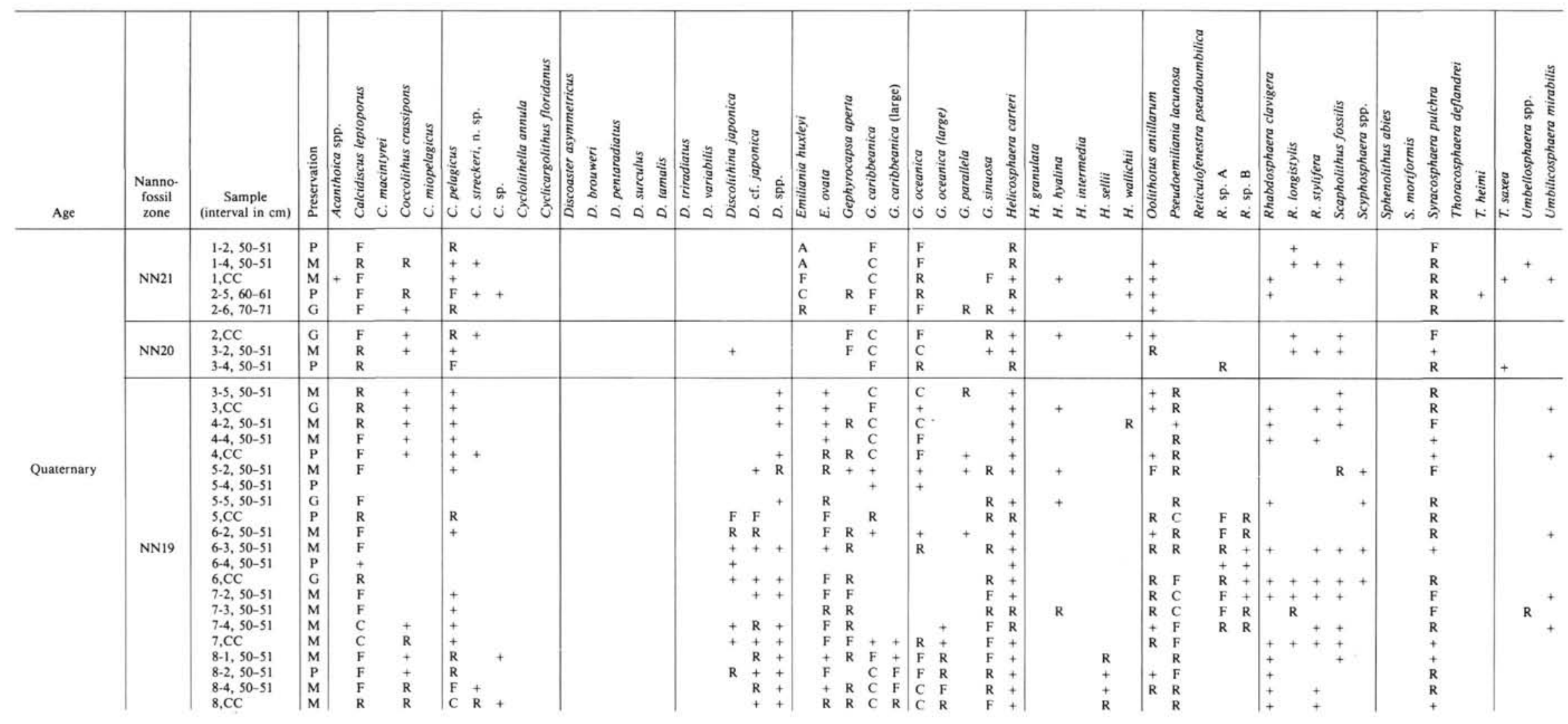




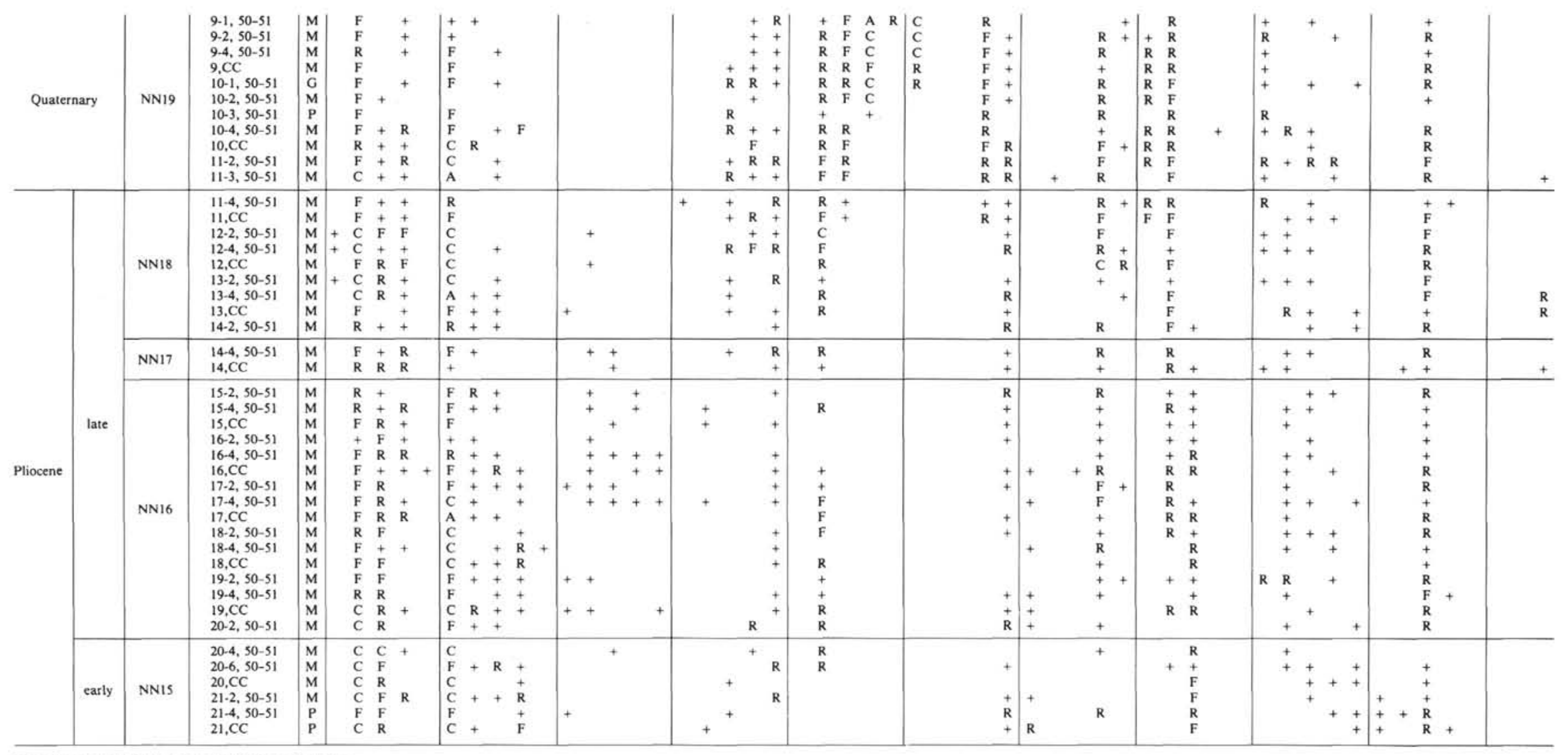

Note: See Table 3 and text for an explanation of symbols. 
Table 16. Distribution of calcareous nannofossils, Hole 610B.

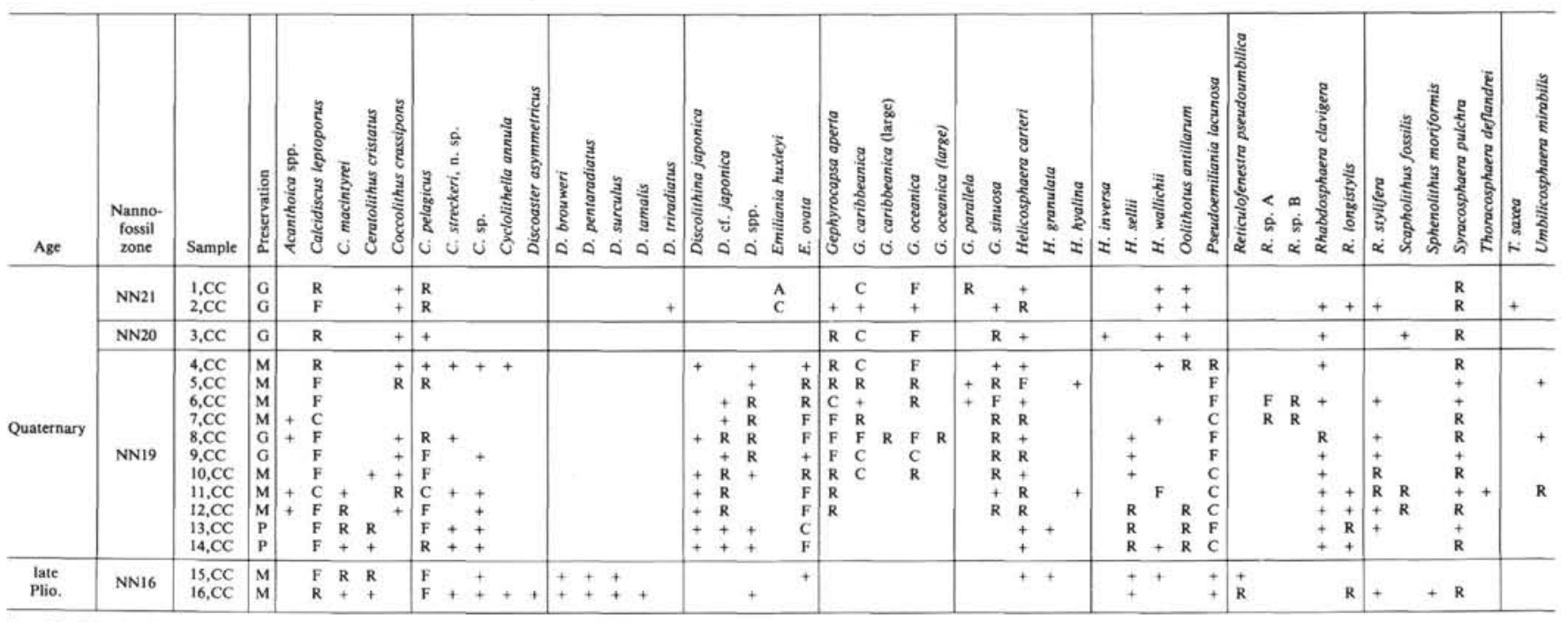

Note: See Table 3 and text for explanation of symbols.

Table 17. Distribution of calcareous nannofossils, Hole 610C.

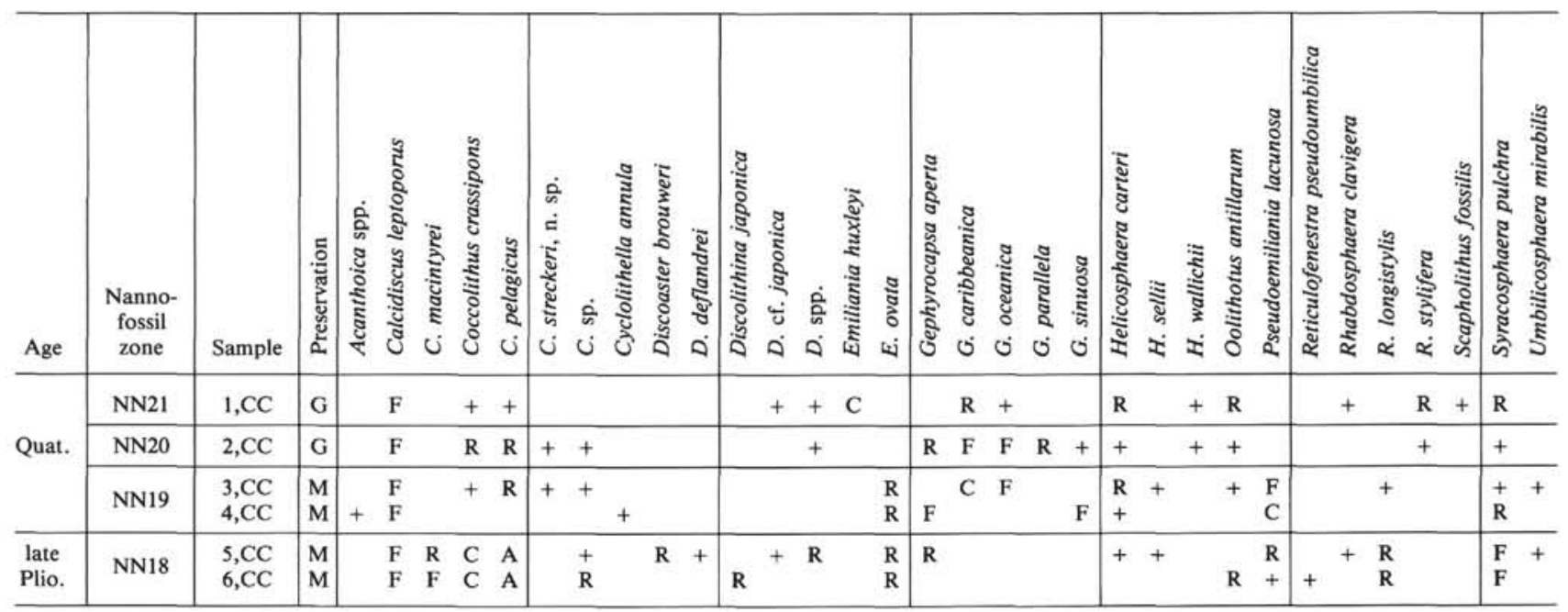

Note: See Table 3 and text for an explanation of symbols.

Table 18. Distribution of calcareous nannofossils, Hole 610D.

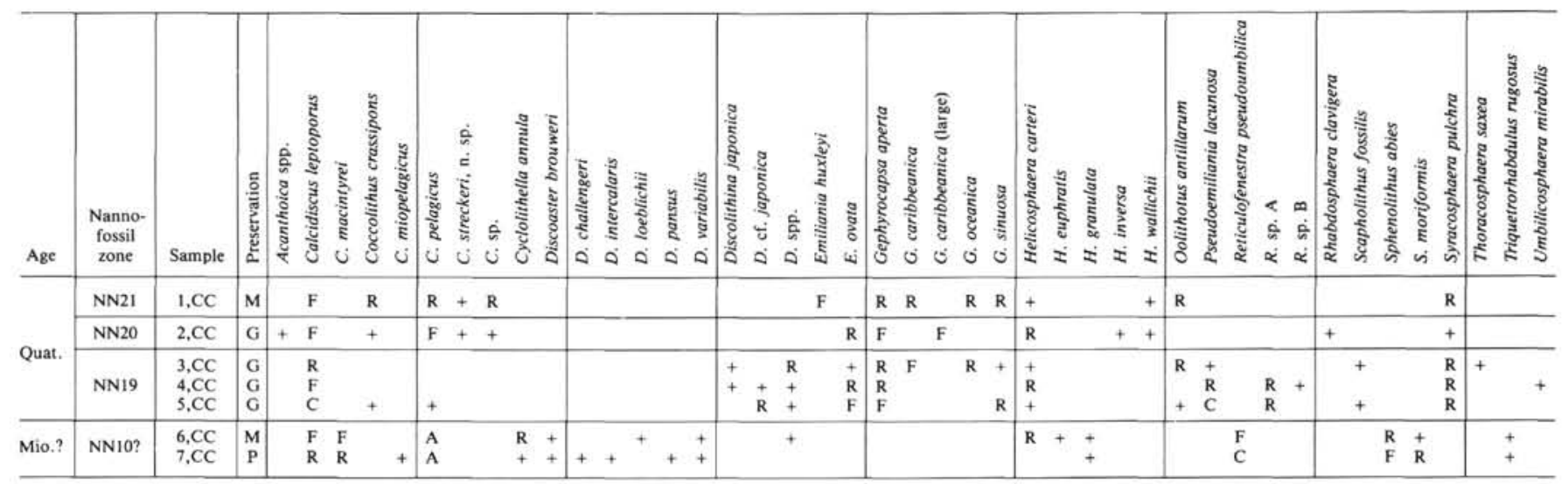

Note: See Table 3 and text for an explanation of symbols. 
Table 19. Distribution of calcareous nannofossils, Hole 610E.

\begin{tabular}{|c|c|c|c|c|c|c|c|c|c|c|c|c|c|c|c|c|c|c|c|c|c|c|c|c|c|c|c|c|}
\hline Age & $\begin{array}{l}\text { Nanno- } \\
\text { fossil } \\
\text { zone }\end{array}$ & ample & 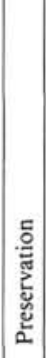 & 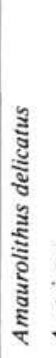 & 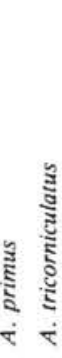 & 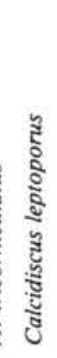 & 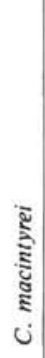 & 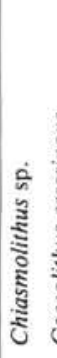 & 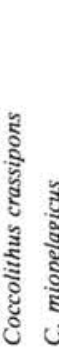 & 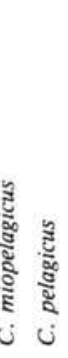 & 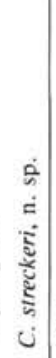 & $\begin{array}{l} \\
\\
0 \\
0 \\
0 \\
0\end{array}$ & 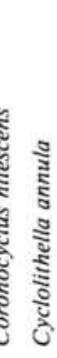 & 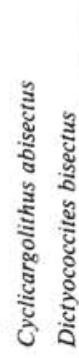 & 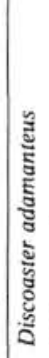 & 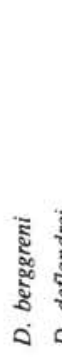 & 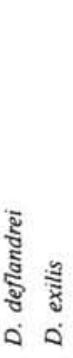 & $\begin{array}{l}\frac{2}{5} \\
\frac{5}{5} \\
\text { है } \\
0\end{array}$ & 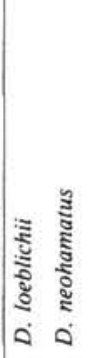 & 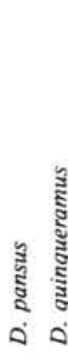 & 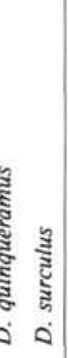 & 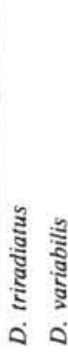 & 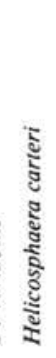 & 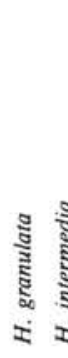 & & 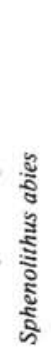 & 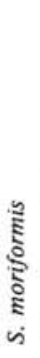 & 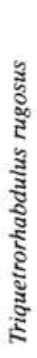 \\
\hline Plio. & NN12 & $1, \mathrm{CC}$ & $\mathrm{M}$ & + & + & C & $\mathrm{F}$ & & & $\mathrm{F} \quad \mathrm{C}$ & & + & + & & & & $+R$ & + & & & + & + & & $R$ & C & & & + \\
\hline \multirow[t]{2}{*}{$\begin{array}{c}\text { late } \\
\text { Miocene }\end{array}$} & NN11 & $\begin{array}{l}2, \mathrm{CC} \\
3, \mathrm{CC} \\
4, \mathrm{CC} \\
5, \mathrm{CC} \\
6, \mathrm{CC}\end{array}$ & $\begin{array}{l}\mathrm{M} \\
\mathrm{M} \\
\mathrm{M} \\
\mathrm{M} \\
\mathrm{M}\end{array}$ & + & $\begin{array}{l}+ \\
+\end{array}$ & $\begin{array}{l}\mathrm{C} \\
\mathrm{F} \\
\mathrm{F} \\
\mathrm{F} \\
\mathrm{F}\end{array}$ & $\begin{array}{l}\mathrm{R} \\
+ \\
\mathrm{F} \\
\mathrm{F} \\
+\end{array}$ & $\begin{array}{l}+ \\
+ \\
+\end{array}$ & 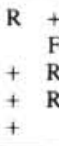 & $\begin{array}{cc}+ & \mathrm{C} \\
\mathrm{F} & \mathrm{A} \\
\mathrm{R} & \mathrm{A} \\
\mathrm{R} & \mathrm{A} \\
& \mathrm{A}\end{array}$ & + & + & $\begin{array}{l}+ \\
+ \\
\text { R }\end{array}$ & $\begin{array}{r}+ \\
+\quad+\end{array}$ & + & $\begin{array}{l}+ \\
+ \\
+ \\
+\end{array}$ & & + & $\begin{array}{l}+ \\
+\end{array}$ & $\begin{array}{r}+ \\
+ \\
+ \\
R \\
+\end{array}$ & $\begin{array}{l}+ \\
+ \\
+ \\
R_{+} \\
+\end{array}$ & $\begin{array}{r}+ \\
+ \\
+ \\
+ \\
+ \\
\text { R }\end{array}$ & + & $\begin{array}{l}+ \\
+ \\
R \\
R\end{array}$ & & $\begin{array}{l}F \\
R \\
R \\
F \\
R\end{array}$ & $\begin{array}{l}\mathrm{R} \\
+ \\
+ \\
+ \\
+\end{array}$ & \\
\hline & NN10 & $7, \mathrm{CC}$ & $\mathrm{M}$ & & & $\mathrm{F}$ & + & & + & A & & & $\mathrm{R}$ & & & & + & & + & & & & $F$ & + & & $\mathrm{R}$ & + & \\
\hline
\end{tabular}

Note: See Table 3 and text for an explanation of symbols.

Amaurolithus and Ceratolithus are absent or extremely rare in this hole, and thus the boundaries between NN15/ NN14 and NN13/NN12 are uncertain. Discoaster quinqueramus first occurs in Sample 31,CC, and the interval from this sample down to $43, \mathrm{CC}$ is assigned to the NN11 (Discoaster quinqueramus Zone). Below this, Samples 44-2, 34-35 cm through 45,CC contain no Discoaster quinqueramus specimens and may belong to NN10 (Discoaster calcaris Zone). In samples from Cores 46 and 47, a few specimens of Discoaster hamatus are found. If these are not reworked specimens, these cores can be assigned to the middle Miocene (NN9, Discoaster hamatus Zone): the bottom sediments of this hole are slightly older than $11 \mathrm{Ma}$.

\section{Hole 611D (Table 24)}

The uppermost sample (Sample 1,CC), which was obtained after washing down to $5.5 \mathrm{~m}$ sub-bottom, is assigned to the early Pleistocene Pseudoemiliania lacunosa Zone (NN19). This sample, characterized by the abundant occurrence of Pseudoemiliania lacunosa and the absence of discoasters, also contains Gephyrocapsa oceanica and G. caribbeanica, but Calcidiscus macintyrei and Helicosphaera sellii are not present. Core-catcher samples from Cores 2 through 11, which were continuously cored after washing down to $128.9 \mathrm{~m}$ sub-bottom, are all placed in the late Pliocene Discoaster surculus Zone (NN16), based on the occurrences of discoasters such as Discoaster brouweri, $D$. pentaradiatus, and $D$. surculus. Although Reticulofenestra pseudoumbilica is present throughout this zone, samples below 12 , CC contain comparatively abundant Reticulofenestra pseudoumbilica. Therefore, the lowest three samples are assigned to NN15 (Reticulofenestra pseudoumbilica Zone).

\section{Hole 611E (Table 25)}

Hole 611E, the last hole drilled during Leg 94, was washed down to $6.5 \mathrm{~m}$ sub-bottom, and two cores were obtained. Core-catcher samples from these cores contain Pseudoemiliania lacunosa, Emiliania ovata, Heli- cosphaera carteri, Calcidiscus leptoporus, Gephyrocapsa caribbeanica, G. oceanica, and Syracosphaera pulchra together with abundant small placoliths referred to $\mathrm{Ge}$ phyrocapsa. Therefore these samples are placed in the early Pleistocene Pseudoemiliania lacunosa Zone (NN19).

\section{DATUM PLANES AND THEIR CALIBRATION TO MAGNETOSTRATIGRAPHY}

The relatively undisturbed cores recovered on Leg 94 are ideally suited for accurate, detailed, and direct correlation of paleomagnetic stratigraphy and biostratigraphy. A detailed paleomagnetic investigation was carried out by Clement and Robinson (this volume).

On the basis of piston cores from numerous ocean basins and land-based marine sections, a late Neogene biochronology was developed over a decade ago. In 1974, Ryan et al. synthesized the available paleomagnetic and biostratigraphic data from numerous piston cores from the equatorial Pacific and Neogene sections in Europe and New Zealand. They presented a compilation of datums for the planktonic foraminifers, radiolarians, and calcareous nannofossils. Until recently these data have been used essentially unchanged as a good working model. Gartner (1973) carried out the first direct correlations of paleomagnetic data and upper Neogene nannofossil biostratigraphy in piston cores from the equatorial Pacific. Subsequently Pleistocene nannofossil biochronology was further investigated and widely documented. Gartner (1977) presented a summary of nannofossil biostratigraphy and suggested a new zonation for this interval.

For the Pliocene and Miocene, however, detailed correlation of coccolith events with magnetostratigraphy was incomplete until Mazzei et al. (1979) investigated the Miocene-Pliocene sequences at DSDP Site 397 (Leg 47, Cape Bojador, eastern Atlantic) for nannofossil and planktonic foraminiferal biostratigraphy together with paleomagnetics. Backman (1979) studied foraminifers and nannofossils from DSDP Sites 111 and 116 (North Atlantic Ocean) and calibrated the ages of some of the 
Table 20. Distribution of calcareous nannofossils, Hole 611.

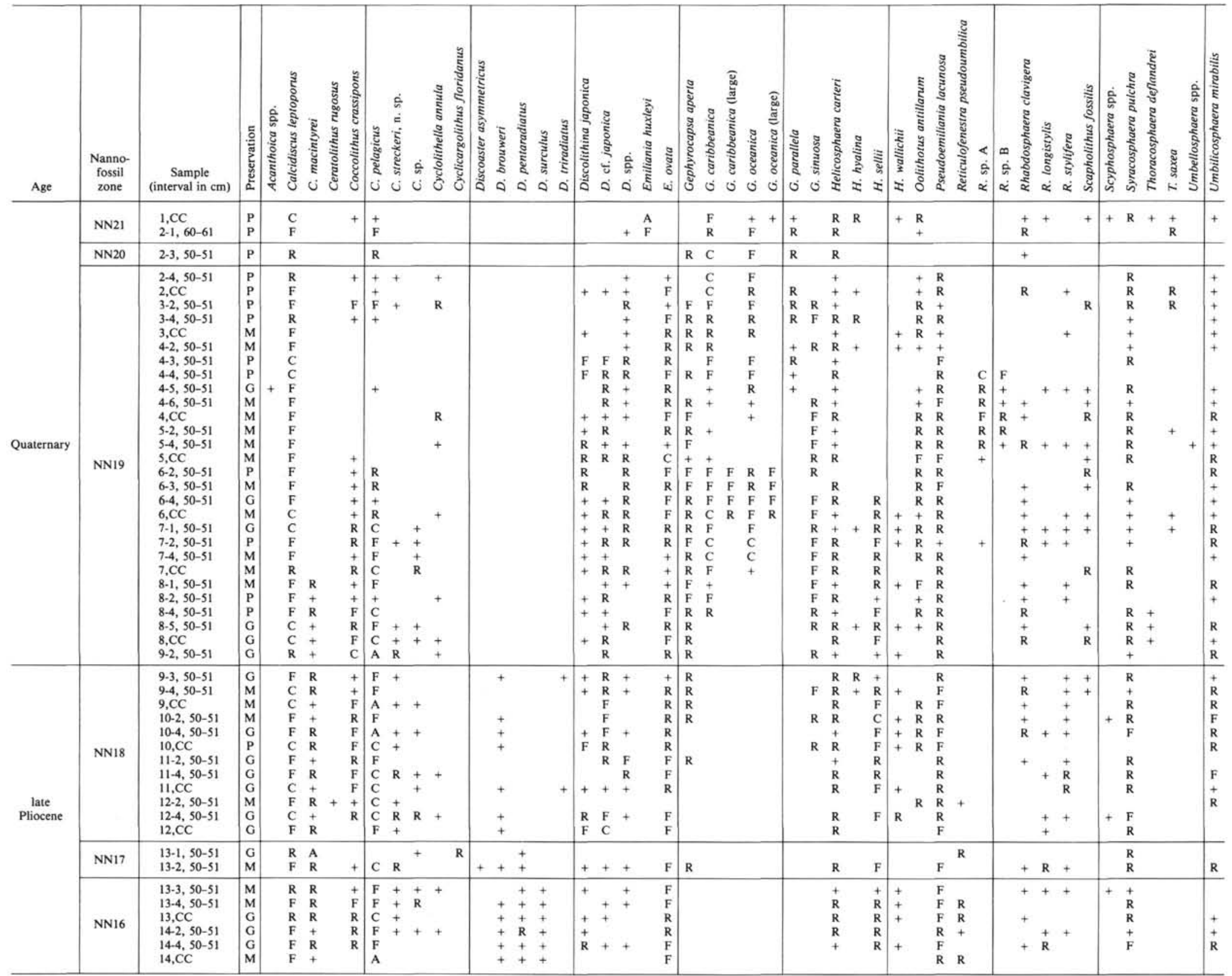


Table 21. Distribution of calcareous nannofossils, Hole 611A.

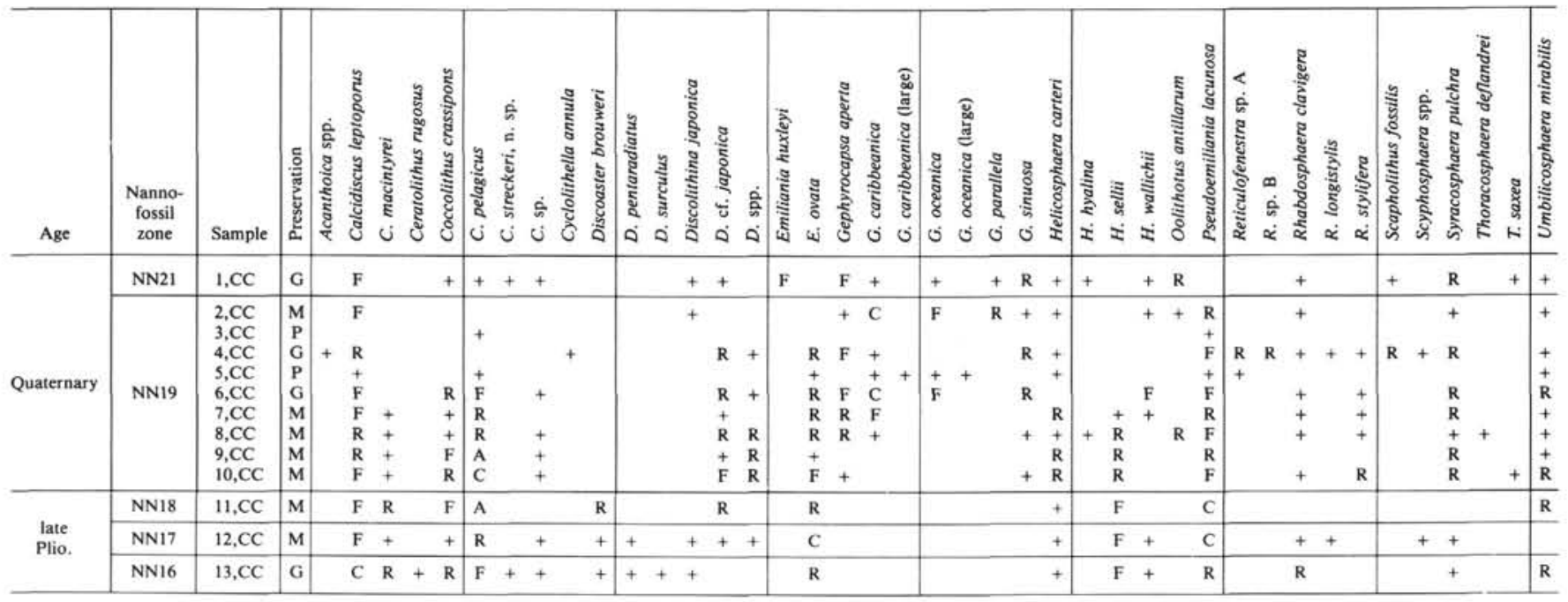

Note: See Table 3 and text for an explanation of symbols.

Table 22. Distribution of calcareous nannofossils, Hole 611B.

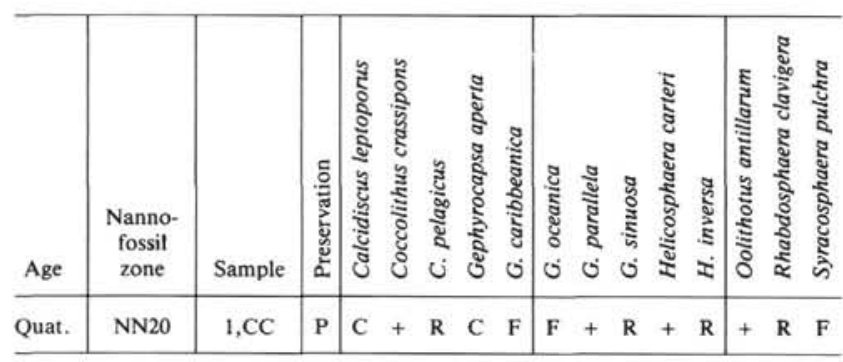

Note: See Table 3 and text for an explanation of symbols.

nannofossil datums. He also investigated some of the coccolith species biometrically (Backman, 1980). Haq et al. (1980) worked on several upper Miocene piston cores and clarified the relationships of coccolith bio- and magnetostratigraphy. Stradner and Allram (1982) and Niitsuma (1982) studied the lower Miocene from DSDP Leg 66, Site 493 in the North Guatemala Basin in the Pacific and correlated the coccolith biostratigraphy with the magnetostratigraphy there. In 1983, Backman and Shackleton estimated the ages of early Pleistocene and Pliocene nannofossil datums by interpolation between magnetic reversals. Site 516 on the Rio Grande Rise cored during Leg 72 was studied by Berggren et al. (1983), and was also investigated by Haq and Takayama (1984) together with paleomagnetically dated piston cores recovered from the equatorial Pacific. In this report, they summarized the Miocene to Recent nannofossil datum events, their correlation with magnetic stratigraphy and their inferred ages, and demonstrated that datum levels in the Pacific and Atlantic oceans seem to be synchronous. DSDP Leg 73 cores allow direct calibrations of magneto- and biostratigraphy for the latest Cretaceous to Cenozoic in the midlatitude South Atlantic Ocean, although the record of the Cenozoic was incomplete (Poore et al., 1984).
Throughout this chapter, we attempted to apply the zonal scheme established by Martini (1971), but many of his zonal marker species are warm-water forms. At Sites 610 and 611, asteroliths and ceratoliths are extremely rare or absent, and this makes it difficult to identify Martini's zones in the lower Pliocene and the upper and middle Miocene sequences.

The following Pliocene-Pleistocene coccolith events were easily recognized (in descending order):
LAD Helicosphaera inversa
FAD Emiliania huxleyi
LAD Pseudoemiliania lacunosa
FAD Helicosphaera inversa
Top of acme Reticulofenestra sp. A
FAD Gephyrocapsa parallela
LAD Gephyrocapsa (large)
LAD Helicosphaera sellii
FAD Gephyrocapsa (large)
FAD Gephyrocapsa oceanica/LAD
Calcidiscus macintyrei
FAD Gephyrocapsa caribbeanica
LAD Sphenolithus abies

Although the following four events were rather difficult to detect at high latitudes (at Sites 610 and 611), they are usable in the present investigation;

\section{LAD Discoaster brouweri \\ LAD Discoaster pentaradiatus \\ LAD Discoaster surculus \\ LAD Discoaster tamalis}

The LAD of Reticulofenestra pseudoumbilica is one of the most important datums, which designates the boundary between the late Pliocene Discoaster surculus Zone (NN16) and the early Pliocene Reticulofenestra pseudoumbilica Zone (NN15). This species, however, occurs throughout the upper Pliocene sequences at all sites studied, which may be attributed to reworking. Therefore we used the top of the acme of this species and interpreted it as the NN16/NN15 boundary, but some- 
Table 23. Distribution of calcareous nannofossils, Hole 611C.

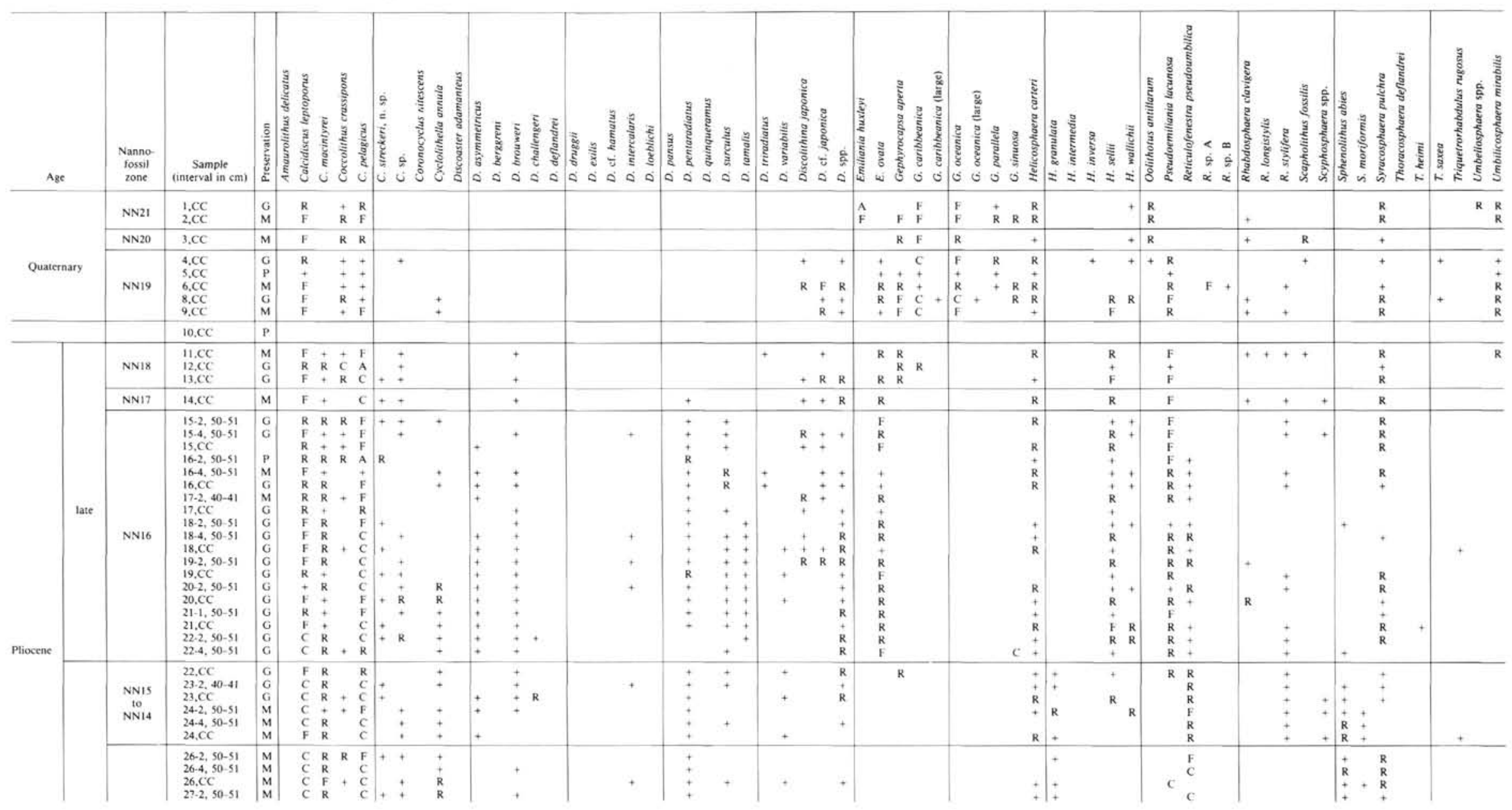




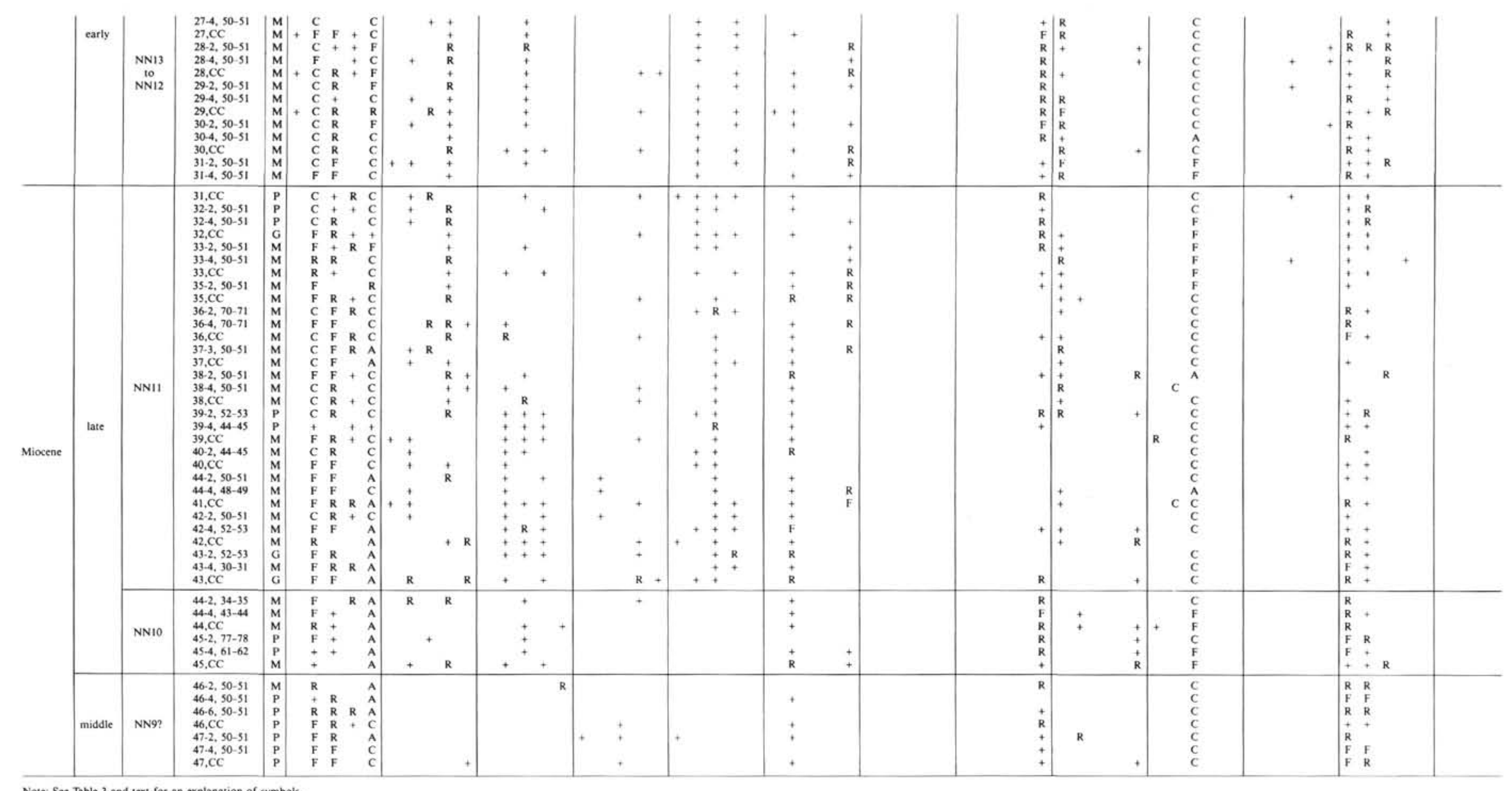

8
8
8
0
1
0
0
0
0
0
0
0
0
0
0
0 
Table 24. Distribution of calcareous nannofossils, Hole 611D.

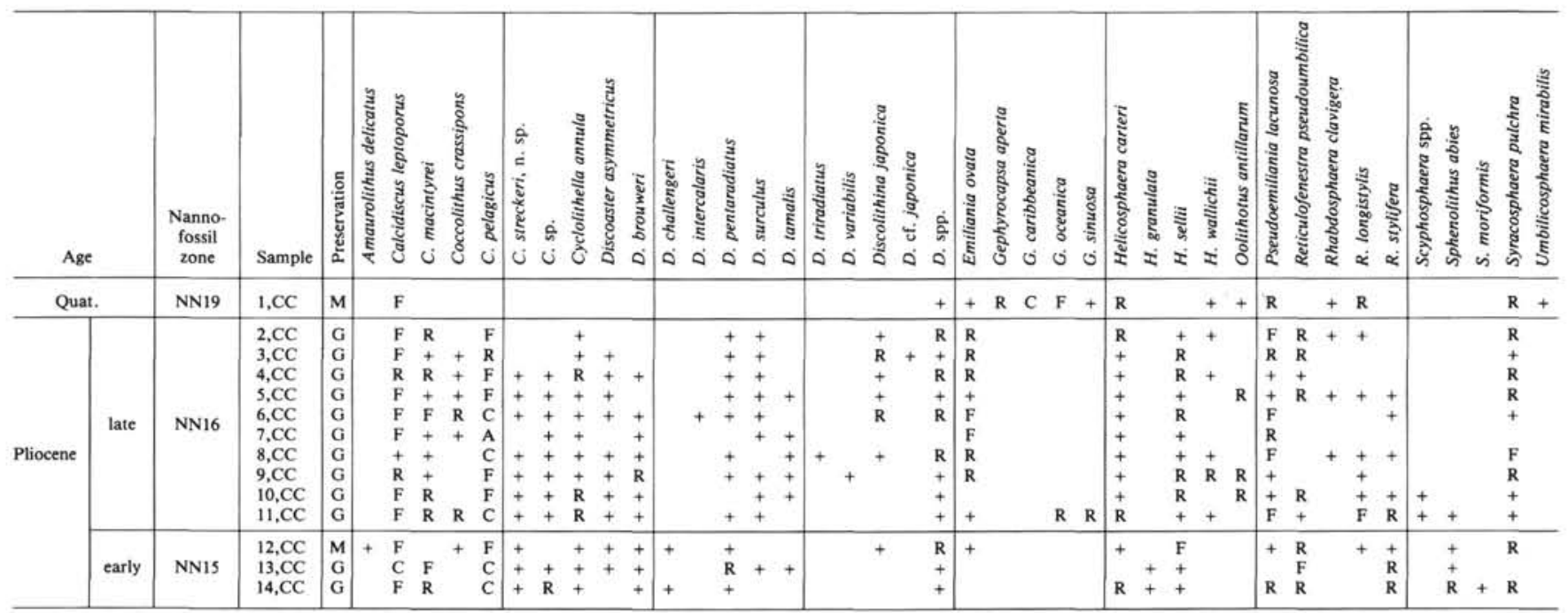

Note: See Table 3 and text for an explanation of symbols.

Table 25. Distribution of calcareous nannofossils, Hole 611E.

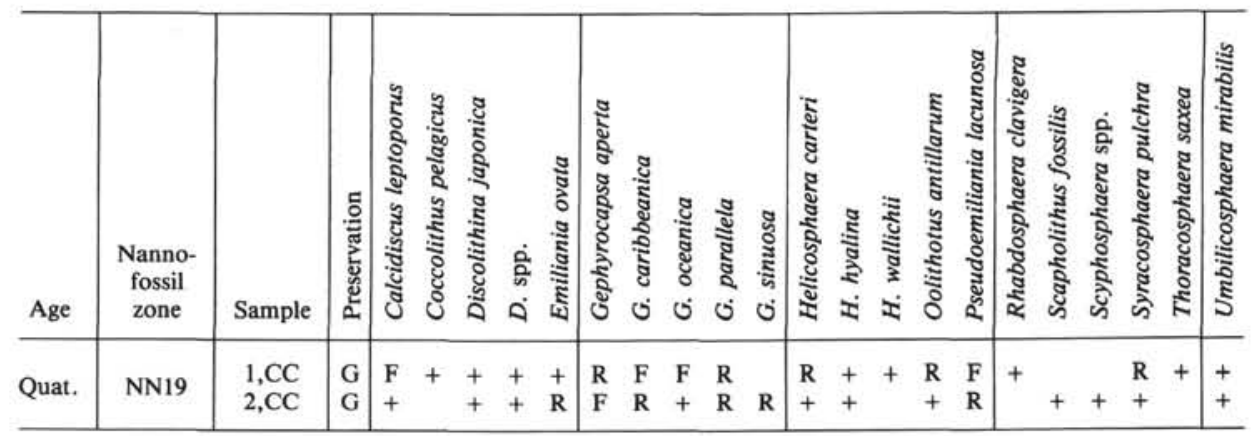

Note: See Table 3 and text for an explanation of symbols.

times it is difficult to recognize the top of the acme precisely.

A continuous Miocene sequence was recovered from Hole 608 , where the following nannofossil events were easily recognized:

\section{LAD Coccolithus miopelagicus \\ LAD Cyclicargolithus floridanus \\ LAD Sphenolithus heteromorphus \\ LAD Sphenolithus belemnos}

The stratigraphic range of Discoaster quinqueramus marks the late Miocene Discoaster quinqueramus Zone (NN11). In the upper part of this zone, the central stem of this species is not prominent, and the upper limit of this zone is difficult to determine. Catinaster coalitus, Discoaster kuglerii, and D. hamatus are very rare. Helicosphaera ampliaperta occurs sporadically.

The stratigraphic levels of all useful calcareous nannofossil events mentioned above are tabulated for each site in Table 26. The magneto- and biostratigraphic relationships of Pliocene and Pleistocene sequences at each site are shown in Figure 2.

Helicosphaera inversa is found only at Sites 606, 607, and 608. The FAD of Emiliania huxleyi and the LAD of Pseudoemiliania lacunosa are recognized in the Brunhes
Chronozone. Seven nannofossil datums in Hole 608 (from the LAD of Helicosphaera sellii to the LAD of Discoaster surculus) are recognized at much higher levels compared to the other sites. This discrepancy may be attributed to redeposition or a small-scale slump, as already mentioned. The FAD of Gephyrocapsa oceanica and the LAD of Calcidiscus macintyrei occur just above the Olduvai Event. At Site 611, however, this datum is slightly below and within the Olduvai Event. The LAD of Discoaster brouweri occurs at around the base of the Olduvai Event, and its synchroneity at different latitudes is demonstrated. The LAD of Discoaster tamalis occurs in the upper part of the Gauss Chronozone. The LAD of Sphenolithus abies is within the uppermost reversed polarity interval of the Gilbert Chronozone and is synchronous at all sites except at Site 610. At this site, this datum occurs well below the expected level, which may be ecologically controlled.

Early and middle Miocene magneto- and biostratigraphic relationships in Hole 608 are shown in Figure 3. The LAD of Coccolithus miopelagicus and Cyclicargolithus floridanus are useful in correlating Miocene sediments at high latitudes; both occur in Chron C5. The LAD of Sphenolithus heteromorphus is in Core 32, which 
Table 26. Calcareous nannofossil events at each site.

\begin{tabular}{|c|c|c|c|c|c|c|}
\hline Datum & 606 & 607 & 608 & 609 & $610 \mathrm{~A}$ & 611 and $611 \mathrm{C}$ \\
\hline Helicosphaera inversa top & $1, \mathrm{CC} / 2-2,47-48$ & $1-4,47-48 / 1, \mathrm{CC}$ & $1-2,46-47 / 1-4,46-47$ & - & - & - \\
\hline Emiliania huxleyi base & $2-2,47-48 / 2-3,47-48$ & $2-2,51-52 / 2-2,47-48$ & $1-4,46-47 / 1-5,46-47$ & $2-2,43-45 / 2, \mathrm{CC}$ & $2-6,70-71 / 2, \mathrm{CC}$ & $2-1,60-61 / 2-3,50-51$ \\
\hline Pseudoemiliania lacunosa top & $2-5,47-48 / 2-6,47-48$ & $2-5,47-48 / 2-6,47-48$ & $2-2,46-47 / 2-3,46-47$ & $3-4,43-45 / 3, \mathrm{CC}$ & $3-4,50-51 / 3-5,50-51$ & $2-3,50-51 / 2-4,50-51$ \\
\hline Helicosphaera inversa base & $2, \mathrm{CC} / 3-2,47-48$ & $3-2,47-48 / 3-4,47-48$ & $2-3,46-47 / 2-4,46-47$ & - & - & - \\
\hline Reticulofenestra sp. A (acme) top & $4-2,47-48 / 4-3,47-48$ & $5-3,47-48 / 5-4,47-48$ & $2, \mathrm{CC} / 3-1,46-47$ & $6-4,43-45 / 6, \mathrm{CC}$ & $5-5,50-51 / 5, \mathrm{CC}$ & $4-3,50-51 / 4-4,50-51$ \\
\hline Gephyrocapsa parallela base & $4-3,47-48 / 4-4,47-48$ & $5-4,47-48 / 5, \mathrm{CC}$ & $3-1,46-47 / 3-2,46-47$ & $6-4,43-45 / 6, \mathrm{CC}$ & $6-2,50-51 / 6-3,50-51$ & $4-5,50-51 / 4-6,50-51$ \\
\hline Gephyrocapsa (large) top & $5-1,47-48 / 5-2,47-48$ & $6-3,47-48 / 6-4,47-48$ & $3-5,46-47 / 3-6,46-47$ & $8, \mathrm{CC} / 9-2,43-45$ & $7-3,50-51 / 7-4,50-51$ & $5, \mathrm{CC} / 6-2,50-51$ \\
\hline Helicosphaera sellii top & $5-3,47-48 / 5-4,47-48$ & $6-5,47-48 / 6-6,47-48$ & $3-5,46-47 / 3-6,46-47$ & $9-2,43-45 / 9-4,43-45$ & $7, \mathrm{CC} / 8-1,50-51$ & $6-3,50-51 / 6-4,50-51$ \\
\hline Gephyrocapsa (large) base & $6-1,47-48 / 6-2,47-48$ & $7-5,47-48 / 7-6,47-48$ & $4-2,46-47 / 4-3,46-47$ & $10-4,43-45 / 10, \mathrm{CC}$ & $9-1,50-51 / 9-2,50-51$ & $6, \mathrm{CC} / 7-1,50-51$ \\
\hline $\left.\begin{array}{l}\text { Calcidiscus macintyrei top } \\
\text { Gephyrocapsa oceanica base }\end{array}\right\}$ & $6-5,47-48 / 6-6,47-48$ & $8-4,47-48 / 8-5,47-48$ & $4-5,46-47 / 4-6,46-47$ & $12-4,43-45 / 12, \mathrm{CC}$ & $10-1,50-51 / 10-2,50-51$ & $7, \mathrm{CC} / 8-1,50-51$ \\
\hline Gephyrocapsa caribbeanica base & $6, \mathrm{CC} / 7-1,47-48$ & $8, \mathrm{CC} / 9-1,47-48$ & $4-5,46-47 / 4-6,46-47$ & $13-2,43-45 / 13-4,43-45$ & $10-3,50-51 / 10-4,50-51$ & $8-4,50-51 / 8-5,50-51$ \\
\hline Discoaster brouweri top & $7-6,47-48 / 7, \mathrm{CC}$ & $9-6,47-48 / 9, \mathrm{CC}$ & $5-4,46-47 / 5-5,46-47$ & $15-2,43-45 / 15-4,43-45$ & $11-3,50-51 / 11-4,50-51$ & $9-2,50-51 / 9-3,50-51$ \\
\hline Discoaster pentaradiatus top & $9-2,47-48 / 9-4,47-48$ & $11-2,47-48 / 11-4,47-48$ & $5-6,46-47 / 5, \mathrm{CC}$ & $19, \mathrm{CC} / 20-1,43-45$ & $14-2,50-51 / 14-4,50-51$ & $12, \mathrm{CC} / 13-1,50-51$ \\
\hline Discoaster surculus top & $9-4,47-48 / 9, \mathrm{CC}$ & $12-2,47-48 / 12-4,47-48$ & $5-6,46-47 / 5, \mathrm{CC}$ & $20-4,43-45 / 20, \mathrm{CC}$ & $14, \mathrm{CC} / 15-2,50-51$ & $13-2,50-51 / 13-3,50-51$ \\
\hline Discoaster tamalis top & $10-4,47-48 / 10, \mathrm{CC}$ & $13-4,47-48 / 13, \mathrm{CC}$ & $10-2,46-47 / 10-4,46-47$ & $22, \mathrm{CC} / 24-1,43-45$ & $16-2,50-51 / 16-4,50-51$ & $17, \mathrm{CC} / 18-2,50-51$ \\
\hline Sphenolithus abies top & $15-2,47-48 / 15-4,47-48$ & $17, \mathrm{CC} / 18-2,47-48$ & $12, \mathrm{CC} / 13-2,46-47$ & $26-4,43-45 / 26, \mathrm{CC}$ & $20, \mathrm{CC} / 21-2,50-51$ & $22-2,50-51 / 22-4,50-51$ \\
\hline Coccolithus miopelagicus top & - & - & $26-3,46-47 / 26-4,46-47$ & - & - & - \\
\hline Cyclicargolithus floridanus top & - & - & $28-2,46-47 / 28-4,36-37$ & - & - & - \\
\hline Sphenolithus heteromorphus top & - & - & $32-5,26-27 / 32, \mathrm{CC}$ & - & - & - \\
\hline Helicosphaera ampliaperta top & - & - & 35. $\mathrm{CC} / 36-2,46-47$ & - & - & - \\
\hline Sphenolithus belemnos (top) & - & - & $28-4,46-47 / 38, \mathrm{CC}$ & - & - & - \\
\hline
\end{tabular}

Note: - indicates no data; top indicates LAD; base indicates FAD.

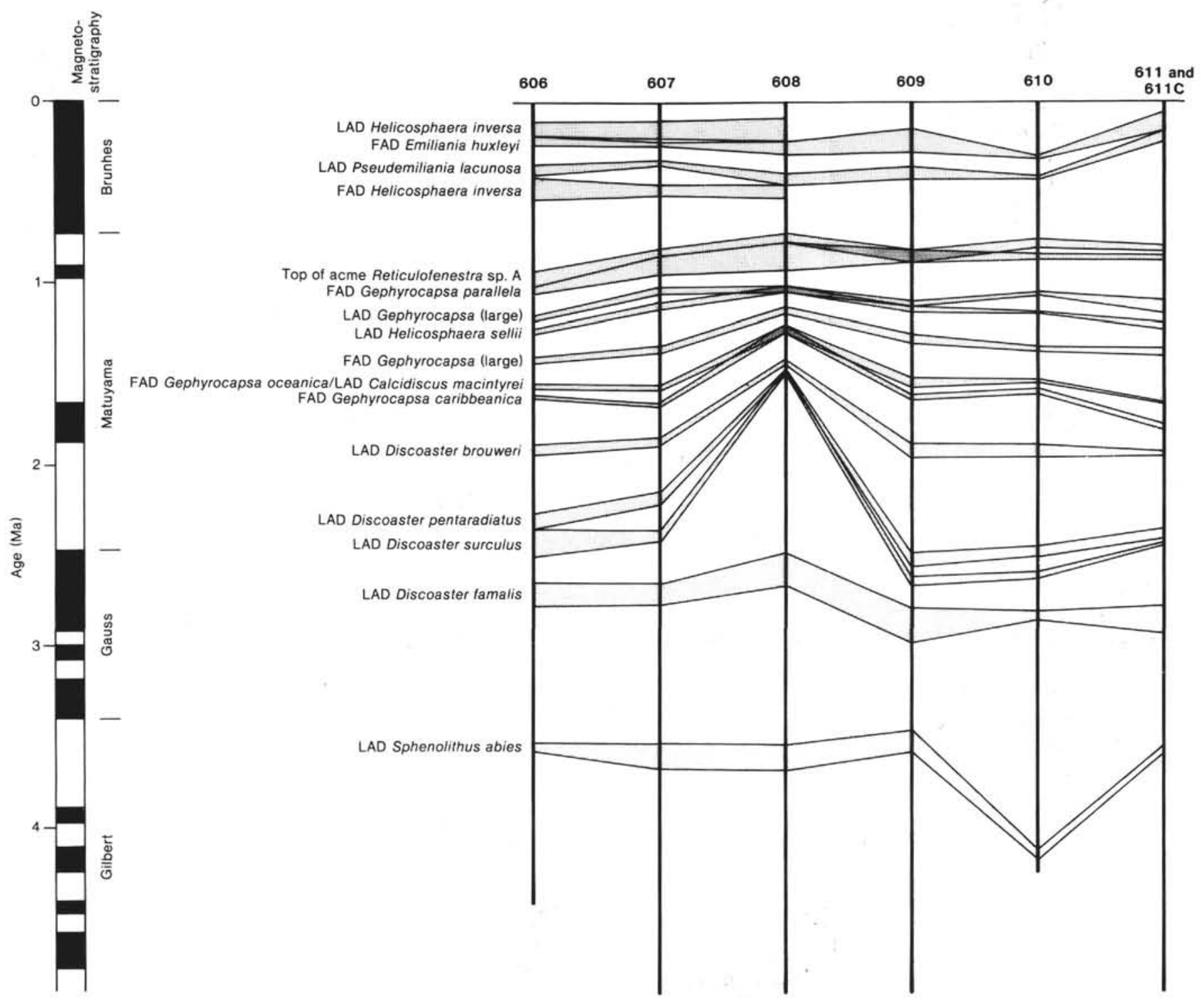

Figure 2. Pliocene-Pleistocene magneto- and biostratigraphic relationships at each site. 


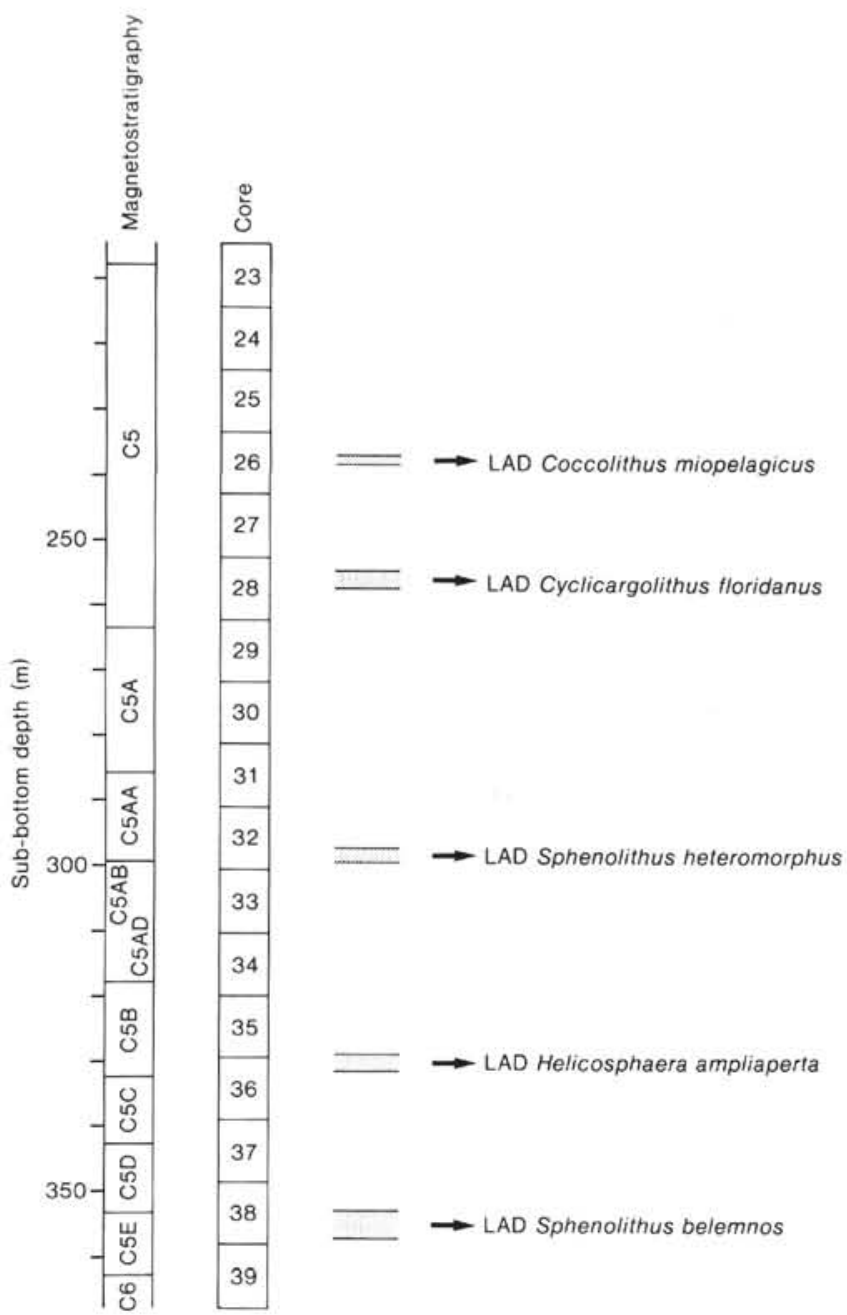

Figure 3. Early to middle Miocene magneto- and biostratigraphic relationships at Site 608.

corresponds to Chron C5AA. Helicosphaera ampliaperta disappears in Cores 35 or 36, and in Chron C5B. We found the LAD of Sphenolithus belemnos in the upper part of Chron C5E or the lowest part of Chron C5D.

The ages of all datums mentioned are estimated at every site by interpolation between magnetic reversals using the time scale of Berggren et al. (in press); the ages are shown in Table 27 . Finally we derived tentatively average ages of these Pleistocene to Miocene calcareous nannofossil events from Table 27 and tabulated them in Table 28 .

Helicosphaera inversa is absent at Sites 610 and 611; and therefore the LAD and the FAD of this species cannot be used at high latitudes. The LAD of Sphenolithus abies may be ecologically controlled, and thus this event is not reliable for age assignments.

\section{FLORAL REFERENCE LIST}

Thirty-one genera and 108 species were recognized during the investigation of the core samples from the Leg 94 holes. One new species is described. The original references are given for each of the species, and brief remarks are added to some. Bibliographic references of previously described species may be found by consulting Loeblich and Tappan (1966, 1968, 1969, 1970a, 1970b, 1971, 1973) and Catalogue of Calcareous Nannofossils by Farinacci (1976-1983).

\section{Genus $A C A N T H O I C A$ Lohmann, 1903}

Acanthoica spp.

\section{Genus AMAUROLITHUS Gartner and Bukry, 1975}

Amaurolithus amplificus (Bukry and Percival)

Ceratolithus amplificus Bukry and Percival, 1971, p. 125, pl. 1, figs. 9-11.

Amaurolithus amplificus (Bukry and Percival) Gartner and Bukry, 1975 , pp. 454,456 , figs. $6 \mathrm{~g}-1$.

\section{Amaurolithus delicatus Gartner and Bukry}

(Plate 6, Figs. 1a, b)

Ceratolithus primus Bukry and Percival, 1971. Bukry 1973, p. 676, pl. 1, fig. 11.

Amaurolithus delicatus Gartner and Bukry, 1975, pp. 456, 457, figs. 7a-f.

Amaurolithus primus (Bukry and Percival) (Plate 6, Figs. 2a, b)

Ceratolithus primus Bukry and Percival, 1971, p. 126, pl. 1, figs. 12-14. Amaurolithus primus (Bukry and Percival) Gartner and Bukry, 1975, p. 457 , figs. $7 \mathrm{~g}-1$.

\section{Amaurolithus tricorniculatus (Gartner)}

(Plate 6, Figs. 3a, b)

Ceratolithus tricorniculatus Gartner, 1967, p. 5, pl. 10, figs. 4-6.

Amaurolithus tricorniculatus (Gartner) Gartner and Bukry, 1975, pp. 457,458 , figs. $8 \mathrm{c}-\mathrm{h}$.

\section{Genus BRAARUDOSPHAERA Deflandre, 1947}

Braarudosphaera bigelowii (Gran and Braarud)

Pontosphaera bigelowii Gran and Braarud, 1935, p. 389, fig. 67.

Braarudosphaera bigelowii (Gran and Braarud) Deflandre, 1947, p. 439 , figs. 1-5.

\section{Genus CALCIDISCUS Kamptner, 1952 Calcidiscus formosus (Kamptner) (Plate 1, Figs. 9a, b)}

Cyclococcolithus formosus Kamptner, 1963, p. 163, pl. 2, fig. 8. Cyclococcolithina formosa (Kamptner) Wilcoxon, 1970, p. 82.

Calcidiscus formosus (Kamptner) Loeblich and Tappan, 1978, p. 1391.

Calcidiscus leptoporus (Murray and Blackman)

(Plate 1, Figs. 6a, b, 7a, b; Plate 8, Figs. 1a, b)

Coccosphaera leptopora Murray and Blackman, 1898, p. 430, pl. 15, figs. 1-7.

Cyclococcolithus leptoporus (Murray and Blackman) Boudreaux and Hay, 1969, pp. 263, 264, pl. 2, figs. 13, 14; pl. 3, figs. 1-6.

Calcidiscus leptoporus (Murray and Blackman) Loeblich and Tappan, 1978, p. 1391.

\section{Calcidiscus macintyrei (Bukry and Bramlette)} (Plate 1, Figs. 8a, b)

Cyclococcolithus macintyrei Bukry and Bramlette, 1969, p. 132, pl. 1, figs. 1-3.

Calcidiscus macintyrei (Bukry and Bramlette) Loeblich and Tappan, 1978 , p. 1392.

Genus CATINASTER Martini and Bramlette, 1963

\section{Catinaster coalitus Martini and Bramlette}

Catinaster coalitus Martini and Bramlette, 1963, p. 851, pl. 103, figs. 7-10. 
Table 27. Calcareous nannofossil events and their ages (Ma) calculated for each site.

\begin{tabular}{lcccccc}
\hline \multicolumn{1}{c}{ Datum } & 606 & 607 & 608 & 609 & $610 \mathrm{~A}$ & $\begin{array}{c}611 \text { and } \\
611 \mathrm{C}\end{array}$ \\
\hline $\begin{array}{l}\text { Helicosphaera inversa top } \\
\text { Emiliania huxleyi base }\end{array}$ & $0.10 / 0.18$ & $0.10 / 0.20$ & $0.09 / 0.22$ & - & - & - \\
$\begin{array}{l}\text { Pseudoemiliania lacunosa top } \\
\text { Helicosphaera inversa base }\end{array}$ & $0.18 / 0.23$ & $0.21 / 0.24$ & $0.22 / 0.29$ & $0.15 / 0.28$ & $0.30 / 0.32$ & $0.06 / 0.16$ \\
Reticulofenestra sp. A (acme) top & $0.41 / 0.53$ & $0.32 / 0.35$ & $0.40 / 0.46$ & $0.36 / 0.43$ & $0.41 / 0.43$ & $0.16 / 0.22$ \\
Gephyrocapsa parallela base & $0.91 / 1.01$ & $0.81 / 0.85$ & $0.46 / 0.53$ & - & - & - \\
Gephyrocapsa (large) top & $1.01 / 1.05$ & $0.85 / 0.95$ & $0.78 / 0.78$ & $0.82 / 0.89$ & $0.76 / 0.81$ & $0.80 / 0.83$ \\
Helicosphaera sellii top & $1.17 / 1.20$ & $1.02 / 1.06$ & $1.02 / 1.05$ & $1.10 / 1.13$ & $1.05 / 1.07$ & $1.10 / 1.17$ \\
Gephyrocapsa (large) base & $1.24 / 1.27$ & $1.10 / 1.14$ & - & $1.13 / 1.16$ & $1.16 / 1.17$ & $1.22 / 1.26$ \\
Calcidiscus macintyrei top & $1.39 / 1.43$ & $1.34 / 1.38$ & - & $1.28 / 1.33$ & $1.35 / 1.38$ & $1.36 / 1.40$ \\
Gephyrocapsa oceanica base & $1.54 / 1.57$ & $1.55 / 1.58$ & - & $1.52 / 1.57$ & $1.53 / 1.55$ & $1.66 / 1.67$ \\
Gephyrocapsa caribbeanica base & $1.60 / 1.62$ & $1.65 / 1.67$ & - & $1.61 / 1.64$ & $1.58 / 1.61$ & $1.78 / 1.81$ \\
Discoaster brouweri top & $1.87 / 1.93$ & $1.84 / 1.89$ & - & $1.88 / 1.93$ & $1.89 / 1.96$ & $1.93 / 1.96$ \\
Discoaster pentaradiatus top & $2.25 / 2.34$ & $2.14 / 2.21$ & - & $2.48 / 2.55$ & $2.45 / 2.50$ & $2.38 / 2.41$ \\
Discoaster surculus top & $2.34 / 2.47$ & $2.35 / 2.41$ & - & $2.60 / 2.65$ & $2.58 / 2.62$ & $2.43 / 2.45$ \\
Discoaster tamalis top & $2.63 / 2.76$ & $2.64 / 2.76$ & $2.48 / 2.66$ & $2.78 / 2.97$ & $2.80 / 2.85$ & $2.77 / 2.92$ \\
Sphenolithus abies top & $3.51 / 3.56$ & $3.52 / 3.66$ & $3.53 / 3.67$ & $3.45 / 3.57$ & $4.10 / 4.16$ & $3.54 / 3.58$ \\
Coccolithus miopelagicus top & - & - & $10.19 / 10.26$ & - & - & - \\
Cyclicargolithus floridanus top & - & - & $10.97 / 11.09$ & - & - & - \\
Sphenolithus heteromorphus top & - & - & $13.14 / 13.19$ & - & - & - \\
Helicosphaera ampliaperta top & - & - & $15.89 / 16.12$ & - & - & - \\
Sphenolithus belemnos top & - & - & $18.57 / 18.91$ & - & - & - \\
\hline
\end{tabular}

Note: Seven datums at Site 608, which are recognized at much higher levels compared to the other sites, are excluded. Dashes at other sites indicate no data available; top indicates LAD; base indicates FAD.

Table 28. Cenozoic calcareous nannofossil datum levels and their average ages derived from Table 27.

\begin{tabular}{lr}
\hline \multicolumn{1}{c}{ Datum } & $\begin{array}{c}\text { Age } \\
\text { (Ma) }\end{array}$ \\
\hline LAD Helicosphaera inversa & 0.15 \\
FAD Emiliania huxleyi & 0.24 \\
LAD Pseudoemiliania lacunosa & 0.39 \\
FAD Helicosphaera inversa & 0.48 \\
Top of acme Reticulofenestra sp. A & 0.83 \\
FAD Gephyrocapsa parallela & 0.89 \\
LAD Gephyrocapsa (large) & 1.10 \\
LAD Helicosphaera sellii & 1.19 \\
FAD Gephyrocapsa (large) & 1.36 \\
LAD Calcidiscus macintyrei & 1.57 \\
FAD Gephyrocapsa oceanica & 1.66 \\
FAD Gephyrocapsa caribbeanica & 1.91 \\
LAD Discoaster brouweri & 2.37 \\
LAD Discoaster pentaradiatus & 2.49 \\
LAD Discoaster surculus & 2.75 \\
LAD Discoaster tamalis & 3.56 \\
LAD Sphenolithus abies & 10.23 \\
LAD Coccolithus miopelagicus & 11.03 \\
LAD Cyclicargolithus floridanus & 13.17 \\
LAD Sphenolithus heteromorphus & 16.01 \\
LAD Helicosphaera ampliaperta & 18.74 \\
LAD Sphenolithus belemnos & \\
\hline
\end{tabular}

\section{Genus CERATOLITHUS Kamptner, 1950}

Ceratolithus acutus Gartner and Bukry

Ceratolithus acutus Gartner and Bukry, 1974, p. 115, pl. 1, figs. 1-4.

\section{Ceratolithus cristatus Kamptner}

Ceratolithus cristatus Kamptner, 1950, p. 154; Bukry and Bramlette, 1968 , p. 150 , pl. 1 , figs. $1,2,4$.

\section{Ceratolithus rugosus Bukry and Bramlette}

(Plate 5, Figs. 10a, b)

Ceratolithus rugosus Bukry and Bramlette, 1968, p. 152, pl. 1, figs. 59.
Ceratolithus telesmus Norris (Plate 5, Figs. 9a, b)

Ceratolithus telesmus Norris, 1965, p. 21, pl. 11, figs. 5-7; pl. 13, figs. 1-3.

Genus CHIASMOLITHUS Hay, Mohler, and Wade, 1966

Chiasmolithus altus Bukry and Percival

(Plate 7, Figs. 4a, b)

Chiasmolithus altus Bukry and Percival, 1971, p. 126, pl. 2, figs. 1, 2.

\section{Chiasmolithus grandis (Bramlette and Riedel)}

(Plate 7, Figs. 7a, b)

Coccolithus grandis Bramlette and Riedel, 1954, p. 391, pl. 38, figs. $1 \mathrm{a}, \mathrm{b}$.

Chiasmolithus grandis (Bramlette and Riedel) Radomski, 1968, p. 560, pl. 44 , figs. 3,4 .

\section{Chiasmolithus oamaruensis (Deflandre)}

(Plate 7, Figs. 6a, b)

Tremalithus oamaruensis Deflandre in Deflandre and Fert, 1954, p. 154, pl. 11, fig. 22, text-figs. $72-74$.

Chiasmolithus oamaruensis (Deflandre) Hay, Mohler, and Wade, 1966, p. 388 , pl. 7 , fig. 1 .

\section{Genus COCCOLITHUS Schwarz, 1894}

Coccolithus crassipons Bouché

(Plate 1, Figs. 1a, b)

Coccolithus crassipons Bouché, 1962, p. 83, pl. 1, figs. 14a, b; textfig. 3 .

\section{Coccolithus eopelagicus (Bramlette and Riedel) \\ (Plate 1, Figs. 3a, b)}

Tremalithus eopelagicus Bramlette and Riedel, 1954, p. 392, pl. 38, figs. $2 \mathrm{a}$, b.

Coccolithus eopelagicus (Bramlette and Riedel) Bramlette and Sullivan, 1961, p. 141.

\section{Coccolithus miopelagicus Bukry}

(Plate 1, Figs. 2a, b)

Coccolithus miopelagicus Bukry, 1971, p. 310, pl. 2, figs. 6-9. 


\section{Coccolithus pelagicus (Wallich)}

Coccosphaera pelagica Wallich, 1877 , p. 348 , pl. 17, figs. 1, 2, 5, 11, 12.

Coccolithus pelagicus (Wallich) Schiller, 1930, p. 246, figs. 123, 124.

Coccolithus streckeri Takayama and Sato, n. sp.

(Plate 1, Figs. 4a, b; Plate 2, Figs. 1-10; Plate 8, Fig. 3)

Name. For Mr. Heinrich Strecker (1892-1981), Austrian composer.

Description. Placolith consisting of two elliptical narrow shields of which the distal shield is slightly larger than the proximal one. A large central opening approximately $3 / 5$ the diameter of the distal shield, spanned by a narrow bridge occupying the minor axis of the ellipse.

Remarks. C. streckeri differs from $C$. pelagicus in having a bridge and a large central opening. The new species resembles $C$. crassipons but differs in having a more prominent bridge. The bridge is fragile, can be easily broken, and was not recognized in many specimens of this new species.

Occurrence. $C$. streckeri is never abundant but occurs in middle Miocene to Recent sediments of DSDP Leg 94.

Size. 5.5 to $7.5 \mu \mathrm{m}$.

Holotype. TOCCN 3538(1) (Plate 1, Figs. 4a, b).

Paratypes. TOCCN 3538(2) to 3538(11) (Plate 2, Figs. 1-10) and TOCCNS 367 (Plate 8, Fig. 3).

Type locality. DSDP Leg 94, Site $608(608-5-5,46-47 \mathrm{~cm})$.

Depository. Technical Research Center, Teikoku Oil Co., Ltd., Tokyo.

Genus CORONOCYCLUS Hay, Mohler, and Wade, 1966 Coronocyclus nitescens (Kamptner)

Umbilicosphaera nitescens Kamptner, 1963, pp. 187, 188, pl. 1, fig. 5. Coronocyclus nitescens (Kamptner) Bramlette and Wilcoxon, 1967, p. 103 , pl. 1 , fig. 5 ; pl. 5 , figs. 7,8 .

Genus CRUCIPLACOLITHUS Hay and Mohler, 1967

Cruciplacolithus spp.

Genus CYCLICARGOLITHUS Bukry, 1971

Cyclicargolithus abisectus (Müller)

(Plate 3, Figs. 1a, b)

Coccolithus? abisectus Müller, 1970, p. 92, pl. 9, figs. 9, 10; pl. 12, fig. 1.

Cyclicargolithus abisectus (Müller) Bukry, 1973, p. 703.

Cyclicargolithus floridanus (Roth and Hay)

(Plate 3, Fig. 2a, b)

Coccolithus floridanus Roth and Hay in Hay, Mohler, Roth, Schmidt, and Boudreaux, 1967, p. 445, pl. 6, figs. 1-4.

Cyclicargolithus floridanus (Roth and Hay) Bukry, 1971, pp. 312, 313.

Genus CYCLOLITHELLA Loeblich and Tappan, 1963

Cyclolithella annula (Cohen)

Coccolithites annulus Cohen, 1964, pp. 237, 238, pl. 3, figs. 1a-e.

Cyclolithella annulus (Cohen) McIntyre and Bé, 1967, p. 568, pl. 5 , figs. A-C.

Genus DICTYOCOCCITES Black, 1967

Dictyococcites bisectus (Hay, Mohler, and Wade)

(Plate 1, Figs. 10a, b)

Syracosphaera bisecta Hay, Mohler, and Wade, 1966, p. 393, pl. 10, figs. 1-6.

Dictyococcites bisectus (Hay, Mohler, and Wade) Bukry and Percival, 1971, p. 127, pl. 2, figs. 12, 13.

\section{Genus DISCOASTER Tan Sin Hok, 1927}

Discoaster adamanteus Bramlette and Wilcoxon

Discoaster adamanteus Bramlette and Wilcoxon, 1967, p. 108, pl. 7, fig. 6 .
Discoaster asymmetricus Gartner

(Plate 6, Fig. 9)

Discoaster asymmetricus Gartner, 1969, p. 598, pl. 1, figs. 1-3.

Discoaster barbadiensis Tan Sin Hok

(Plate 6, fig. 16)

Discoaster barbadiensis Tan Sin Hok, 1927, p. 119.

\section{Discoaster berggrenii Bukry}

(Plate 6, Fig. 12)

Discoaster berggrenii Bukry, 1971, p. 45, pl. 2, figs. 4-6.

Discoaster binodosus Martini

Discoaster binodosus Martini, 1958, p. 361, pl. 4, fig. 18b.

Discoaster brouweri Tan Sin Hok

(Plate 6, Fig. 6)

Discoaster brouweri Tan Sin Hok, 1927, p. 120, figs. 8a, b. Bramlette and Riedel, 1954, p. 402, pl. 39, fig. 12.

\section{Discoaster challengeri Bramlette and Riedel}

Discoaster challengeri Bramlette and Riedel, 1954, p. 401, pl. 39, fig. 10.

\section{Discoaster deflandrei Bramlette and Riedel}

Discoaster deflandrei Bramlette and Riedel, 1954, p. 399, pl. 39, fig. 6; text-figs. 1a-c.

\section{Discoaster druggii Bramlette and Wilcoxon}

Discoaster druggii Bramlette and Wilcoxon, 1967, p. 110, pl. 8, figs. 2-8. Bramlette and Wilcoxon, 1967, p. 220.

Discoaster exilis Martini and Bramlette

Discoaster exilis Martini and Bramlette, 1963, p. 852, pl. 104, figs. 1-3.

\section{Discoaster hamatus Martini and Bramlette}

(Plate 6, Fig. 13)

Discoaster hamatus Martini and Bramlette, 1963, p. 852, pl. 105, figs. $8,10,11$.

\section{Discoaster intercalaris Bukry}

Discoaster intercalaris Bukry, 1971, p. 315, pl. 3, fig. 12; pl. 4, figs. 1, 2.

\section{Discoaster kuglerii Martini and Bramlette}

(Plate 6, Fig. 15)

Discoaster kugleri Martini and Bramlette, 1963, p. 853, pl. 102, figs. $11-13$.

Discoaster loeblichi Bukry

(Plate 6, Fig. 14)

Discoaster loeblichi Bukry, 1971, pp. 315, 316, pl. 4, figs. 3-5.

Discoaster pansus (Bukry and Percival)

Discoaster variabilis pansus Bukry and Percival, 1971, p. 129, pl. 3, figs. 8, 9.

Discoaster pansus (Bukry and Percival) Bukry, 1973, p. 678.

\section{Discoaster pentaradiatus Tan Sin Hok}

(Plate 6, Fig. 7)

Discoaster pentaradiatus Tan Sin Hok, 1927, p. 120, fig. 2; sens. emend. Bramlette and Riedel, 1954, p. 401, pl. 39, fig. 11; text-figs. 2a, b.

\section{Discoaster quadrams Bukry}

Discoaster quadrams Bukry, 1973, p. 307, pl. 1, figs. 5, 6. 


\section{Discoaster quinqueramus Gartner}

(Plate 6, Fig. 11)

Discoaster quinqueramus Gartner, 1969, p. 598, pl. 1, figs. 6, 7.

Discoaster saipanensis Bramlette and Riedel

(Plate 6, Fig. 17)

Discoaster saipanensis Bramlette and Riedel, 1954, p. 398, pl. 39, fig. 4.

\section{Discoaster surculus Martini and Bramlette} (Plate 6, Fig. 8)

Discoaster surculus Martini and Bramlette, 1963, p. 854, pl. 104, figs. 10-12.

\section{Discoaster tamalis Kamptner}

(Plate 6, Fig. 5)

Discoaster tamalis Kamptner, 1967, p. 166, text-fig. 29.

\section{Discoaster tani Bramlette and Riedel} (Plate 7, Fig. 1)

Discoaster tani Bramlette and Riedel, 1954, p. 397, pl. 39, fig. 1.

\section{Discoaster tani nodifer Bramlette and Riedel}

Discoaster tani nodifer Bramlette and Riedel, 1954, p. 397, pl. 38, fig. 2 .

\section{Discoaster triradiatus Tan Sin Hok}

(Plate 6, Fig. 4)

Discoaster triradiatus Tan Sin Hok, 1927, p. 417.

\section{Discoaster variabilis Martini and Bramlette}

(Plate 6, Fig. 10)

Discoaster variabilis Martini and Bramlette, 1963, p. 854, pl. 104, figs. 4-9.

\section{Genus DISCOLITHINA Loeblich and Tappan, 1963}

Discolithina japonica Takayama

(Plate 4, Figs. 6a, b)

Discolithina japonica Takayama, 1967, p. 189, pls. 9, 10; text-fig. 7.

\section{Genus EMILIANIA Hay and Mohler in Hay et al., 1967}

Emiliania huxleyi (Lohmann)

(Plate 3, Figs. 6a, b)

Pontosphaera huxleyi Lohmann, 1902, p. 130, pl. 4, figs. 1-6; pl. 6, fig. 69.

Coccolithus huxleyi (Lohmann) Kamptner, 1943, p. 44.

Emiliania huxleyi (Lohmann) Hay and Mohler, in Hay, Mohler, Roth, Schmidt, and Boudreaux, 1967, p. 447, pls. 10, 11, figs. 1, 2.

\section{Emiliania ovata Bukry}

Emiliania ovata Bukry, 1973, p. 678, pl. 2, figs. 10-12.

\section{Genus GEPHYROCAPSA Kamptner, 1943}

Gephyrocapsa aperta Kamptner

Gephyrocapsa aperta Kamptner, 1963, p. 173, pl. 6, figs. 32-35.

\section{Gephyrocapsa caribbeanica Boudreaux and Hay}

Gephyrocapsa caribbeanica Boudreaux and Hay, in Hay, Mohler, Roth, Schmidt, and Boudreaux, 1967, p. 447, pls. 12, 13, figs. 1-4.

Remarks. Calcareous nannofossil assemblages in the Leg 94 Pleistocene to Holocene sequence are characterized by dominance of $\mathrm{Ge}$ phyrocapsa. Most of these Gephyrocapsa are smaller than $4 \mu \mathrm{m}$. In this study, Gephyrocapsa caribbeanica was identified by the characteristic features such as the size (larger than $4 \mu \mathrm{m}$ ) and orientation of the diagonal bar (over $45^{\circ}$ angle with the short axis). Specimens that are larger than $6 \mu \mathrm{m}$ are put in "Gephyrocapsa caribbeanica (large type)."

\section{Gephyrocapsa oceanica Kamptner}

(Plate 3, Figs. 9a, b)

Gephyrocapsa oceanica Kamptner, 1943, pp. 43-49.

Remarks. Gephyrocapsa oceanica was identified by size (larger than $4 \mu \mathrm{m}$ ) and orientation of the diagonal bar (less than $45^{\circ}$ angle with the short axis). Specimens that are larger than $6 \mu \mathrm{m}$ were put in " $\mathrm{Ge}$ phyrocapsa oceanica (large type)."

\section{Gephyrocapsa parallela Hay and Beaudry}

(Plate 3, Figs. 8a, b)

Gephyrocapsa parallela Hay and Beaudry, 1973, p. 672, pl. 1, figs. 10-12.

\section{Gephyrocapsa sinuosa Hay and Beaudry}

(Plate 3, Figs. 10a, b)

Gephyrocapsa sinuosa Hay and Beaudry, 1973, p. 672, pl. 1, figs. 13, 14.

\section{Genus HAYASTER Bukry, 1973}

Hayaster perplexus (Bramlette and Riedel)

Discoaster perplexus Bramlette and Riedel, 1954, p. 400, pl. 39, fig. 9. Hayaster perplexus (Bramlette and Riedel) Bukry, 1973, p. 308, pl. 27, fig. 1.

\section{Genus HELICOSPHAERA Kamptner, 1954}

\section{Helicosphaera ampliaperta Bramlette and Wilcoxon}

Helicosphaera ampliaperta Bramlette and Wilcoxon, 1967, p. 105, pl. 6, figs. 1-4.

\section{Helicosphaera carteri (Wallich)}

(Plate 4, Figs. 2a, b)

Coccosphaera carteri Wallich, 1877, p. 348.

Coccolithus carteri (Wallich) Kamptner, 1941, pp. 93, 111, pl. 13, fig. 136.

Helicosphaera carteri (Wallich) Kamptner, 1954, p. 21, text-figs. 17-19.

Helicosphaera compacta Bramlette and Wilcoxon

Helicosphaera compacta Bramlette and Wilcoxon, 1967, p. 105, figs. 5-8.

Helicopontosphaera compacta (Bramlette and Wilcoxon) Hay, 1970, p. 458.

\section{Helicosphaera euphratis Haq}

Helicosphaera euphratis Haq, 1966, p. 33, pl. 2, figs. 1, 3.

Helicopontosphaera euphratis (Haq) Martini, 1969, p. 136.

Helicosphaera granulata (Bukry and Percival)

Helicopontosphaera granulata Bukry and Percival, 1971, p. 132; pl. 5, figs. 1,2

Helicosphaera granulata (Bukry and Percival) Jafar and Martini, 1975, p. 390.

Helicosphaera hyalina Gaarder

Helicosphaera hyalina Gaarder, 1970, p. 113, 114; text-figs. 1-3.

\section{Helicosphaera intermedia Martini}

Helicosphaera intermedia Martini, 1965, p. 404; pl. 35, figs. 1, 2.

\section{Helicosphaera inversa (Gartner) (Plate 4, Figs. 3a, b)}

Helicopontosphaera inversa Gartner, 1977, p. 23, pl. 1, figs. 4, 5. Helicosphaera inversa (Gartner) Haq, in Haq and Berggren, 1978, p. 1192.

Helicosphaera obliqua, Bramlette and Wilcoxon

Helicosphaera obliqua Bramlette and Wilcoxon, 1967, p. 106; pl. 5, figs. 13,14 . 
Helicopontosphaera obliqua (Bramlette and Wilcoxon) Haq, 1973, p. 40 ; pl. 4 , fig. 6 ; pl. 5 , figs. 7,8 .

\section{Helicosphaera perch-nielseniae (Haq) \\ (Plate 4, Figs. 5a, b)}

Helicopontosphaera perch-nielseniae Haq, 1971, p. 116; pl. 10, figs. 5-7.

Helicosphaera perch-nielseniae (Haq) Jafar and Martini, 1975, p. 391.

\section{Helicosphaera recta $\mathrm{Haq}$}

Helicosphaera recta Haq, 1966, p. 34, pl. 2, fig. 6; pl. 3, fig. 4.

\section{Helicosphaera sellii (Bukry and Bramlette)}

(Plate 4, Figs. 4a, b)

Helicopontosphaera sellii Bukry and Bramlette, 1969, p. 134, pl. 2, figs. 3-7.

Helicosphaera sellii (Bukry and Bramlette) Jafar and Martini, 1975, p. 391.

\section{Helicosphaera wallichi (Lohmann)}

(Plate 4, Figs. 1a, b)

Coccolithophora wallichi Lohmann, 1902, p. 138, pl. 5, figs. 58-60.

Helicopontosphaera wallichi (Lohmann) Boudreaux and Hay, 1969, pp. 272,273 , pl. 6 , fig. 9 .

Helicosphaera wallichi (Lohmann) Okada and McIntyre, 1977, pp. 14,15 , pl. 4 , fig. 8 .

Genus ISTHMOLITHUS Deflandre in Deflandre and Fert, 1954

\section{Isthmolithus recurvus Deflandre}

(Plate 7, Figs. 2, 3)

Isthmolithus recurvus Deflandre, in Deflandre and Fert, 1954, p. 169, pl. 12, figs. 9-13; text-figs. 119-122.

\section{Genus OOLITHOTUS Reinhardt, 1968 \\ Oolithotus antillarum (Cohen) \\ (Plate 4, Figs. 7a, b)}

Discolithus antillarum Cohen, 1964, p. 236, pl. 1, figs. 3a-e; pl. 2 , figs. 2a-b.

Oolithotus antillarum (Cohen) Reinhardt, 1968, p. 297, pl. 31, fig. 8 .

\section{Genus PSEUDOEMILIANIA Gartner, 1969}

Pseudoemiliania lacunosa (Kamptner)

(Plate 3, Figs. 7a, b; Plate 8, Fig. 2)

Ellipsoplacolithus lacunosus Kamptner, 1963, p. 172, pl. 9, fig. 50.

Pseudoemiliania lacunosa (Kamptner) Gartner, 1969, p. 598, pl. 2, figs. 9, 10.

\section{Genus RETICULOFENESTRA Hay et al., 1966 \\ Reticulofenestra dictyoda (Deflandre and Fert)}

Discolithus dictyoda Deflandre and Fert, 1954, p. 140, text-figs. 15, 16.

Reticulofenestra dictyoda (Deflandre and Fert) Stradner, in Stradner and Edwards, 1968, p. 19. Perch-Nielsen, 1971, p. 30, pl. 25, figs. 1-3. Romein, 1979, p. 128, pl. 4, fig. 6.

\section{Reticulofenestra hillae Bukry and Percival}

Reticulofenestra hillae Bukry and Percival, 1971, p. 136, pl. 6, figs. $1-3$.

\section{Reticulofenestra pseudoumbilica (Gartner)}

(Plate 3, Figs. 4 a, b)

Coccolithus pseudoumbilicus Gartner, 1967, p. 4, pl. 6, fig. 3.

Reticulofenestra pseudoumbilica (Gartner) Gartner, 1969, pp. 587-598.

\section{Reticulofenestra reticulata (Gartner and Smith)}

(Plate 3, Figs. 5a, b)

Cyclococcolithus reticulata Gartner and Smith, 1967, p. 4, pl. 5 figs. $1-4$.
Reticulofenestra reticulata (Gartner and Smith) Roth, in Roth and Thierstein, 1972, p. 436.

$$
\begin{gathered}
\text { Reticulofenestra umbilica (Levin) } \\
\text { (Plate 7, Figs. 5a, b) }
\end{gathered}
$$

Coccolithus umbilicus Levin, 1965, p. 265, pl. 41, fig. 2.

Reticulofenestra umbilica (Levin) Martini and Ritzkowski, 1968, p. 245 , pl. 1, figs. 11,12 .

\section{Reticulofenestra sp. A}

(Plate 3, Figs. 3a, b)

Remarks. Reticulofenestra sp. A is distinguished from Crenalithus doronicoides (Black and Barnes) Roth by its larger size (larger than $6 \mu \mathrm{m}) . R$. sp. A is rare to common near the base of occurrence of $G e-$ phyrocapsa parallela.

\section{Reticulofenestra sp. B}

Remarks. Reticulofenestra sp. B, which appears in the same horizon as Reticulofenestra sp. A, is distinguished from $R$. sp. A by its circular form.

\section{Reticulofenestra sp. C}

Remarks. Reticulofenestra sp. C differs from $R$. pseudoumbilica (Gartner) Gartner in being smaller. Although this form appears closely related to $R$. gartneri Roth and Hay, its diagnostic character is not clear under the light microscope. This form is, therefore, put in $R$. sp. $\mathrm{C}$ in the present investigation.

\section{Genus RHABDOSPHAERA Haeckel, 1894}

Rhabdosphaera clavigera Murray and Blackman (Plate 4, Figs. 9a, b)

Rhabdosphaera clavigera Murray and Blackman, 1898, p. 438, pl. 15, figs. 13-15.

\section{Rhabdosphaera longistylis Schiller}

Rhabdosphaera longistylis Schiller, 1925, p. 40, pl. 4, fig. 40.

\section{Rhabdosphaera stylifera Lohmann}

(Plate 4, Figs. 10a, b)

Rhabdosphaera stylifer Lohman, 1902, p. 143, pl. 5, fig. 65.

Aspidorhabdus stylifer (Lohman) Boudreaux and Hay, 1969, p. 269, pl. 5, figs. 11-15.

Genus SCAPHOLITHUS Deflandre in Deflandre and Fert, 1954 Scapholithus fossilis Deflandre

Scapholithus fossilis Deflandre, in Deflandre and Fert, 1954, p. 165, pl. 8 , figs. $12,16,17$.

Genus SCYPHOSPHAERA Lohmann, 1902

Scyphosphaera spp.

\section{Genus SPHENOLITHUS Deflandre, 1952}

Sphenolithus abies Deflandre

(Plate 5, Fig. 1a, b)

Sphenolithus abies Deflandre, 1953, p. 1785. Deflandre in Deflandre and Fert, 1954, p. 164, pl. 10, figs. 1-4.

\section{Sphenolithus belemnos Bramlette and Wilcoxon} (Plate 5, Figs. 4a, b)

Sphenolithus belemnos Bramlette and Wilcoxon, 1967, p. 118, pl. 2, figs. 1-3.

\section{Sphenolithus ciperoensis Bramlette and Wilcoxon} (Plate 5, Figs. 5a, b)

Sphaerolithus ciperoensis Bramlette and Wilcoxon, 1967, p. 120, pl. 2, figs. 15-18. 
Sphenolithus conicus Bukry

Sphenolithus conicus Bukry, 1971, p. 320, pl. 5, figs. 10-12.

Sphenolithus delphix Bukry

Sphenolithus delphix Bukry, 1973, p. 679, pl. 3, figs. 19-22.

Sphenolithus dissimilis Bukry and Percival

Sphenolithus dissimilis Bukry and Percival, 1971, p. 140, pl. 6, figs. 7-9.

\section{Sphenolithus distentus (Martini)}

(Plate 5, Figs. 6a, b)

Furcatolithus distentus Martini, 1965, p. 407, pl. 35, figs. 7-9. Sphenolithus distentus (Martini) Bramlette and Wilcoxon, 1967, p. 122, pl. 1 , fig. 5 .

\section{Sphenolithus heteromorphus Deflandre}

(Plate 5, Figs. 3a, b)

Sphenolithus heteromorphus Deflandre, 1953, pp. 1785, 1786, figs. 1 , 2.

\section{Sphenolithus moriformis (Brönniman and Stradner)}

(Plate 5, Figs. 2a, b)

Nannoturbella moriformis Brönniman and Stradner, 1960, p. 368 , figs. 11-16.

Sphenolithus moriformis (Brönniman and Stradner) Bramlette and Wilcoxon, 1967, pp. 124-126, pl. 3, figs. 1-6.

Sphenolithus predistentus Bramlette and Wilcoxon (Plate 5, Figs. 7a, b, 8a, b)

Sphenolithus predistentus Bramlette and Wilcoxon, 1967, p. 126, pl. 1, fig. 6; pl. 2, figs. 10, 11 .

\section{Sphenolithus radians Deflandre}

Sphenolithus radians Deflandre in Grassé, 1952, p. 466, figs. 343J-K, 363A-G.

\section{Genus SYRACOSPHAERA Lohmann, 1902}

Syracosphaera pulchra Lohmann

Syracosphaera pulchra Lohmann, 1902, p. 134; pl. 4, figs. 33, 36, 37.

\section{Genus THORACOSPHAERA Kamptner, 1927}

Thoracosphaera deflandrei Kamptner

Thoracosphaera deflandrei Kamptner, 1956, p. 448, figs. 1-4.

\section{Thoracosphaera heimi (Lohmann)}

(Plate 4, Figs. 8a, b)

Syracosphaera heimi Lohmann, 1919, p. 117, fig. 29.

Thoracosphaera heimi (Lohmann) Kamptner, 1954, pp. 40-42; figs. $41,42$.

\section{Thoracosphaera saxea Stradner}

Thoracosphaera saxea Stradner, 1961, p. 84, fig. 71.

\section{Genus TRIQUETRORHABDULUS Martini, 1965 Triquetrorhabdulus carinatus Martini}

Triquetrorhabdulus carinatus Martini, 1965, p. 408, pl. 36, figs. 1-3.

Triquetrorhabdulus rugosus Bramlette and Wilcoxon

Triquetrorhabdulus rugosus Bramlette and Wilcoxon, 1967, p. 128, pl. 9, figs. 17, 18.

Genus UMBELLOSPHAERA Paasche in Markali and Paasche, 1955

Umbellosphaera spp.
Genus UMBILICOSPHAERA Lohmann, 1902

Umbilicosphaera mirabilis Lohmann

Umbilicosphaera mirabilis Lohmann, 1902, p. 139, pl. 5, figs. 66, 66a.

Genus ZYGRHABLITHUS Deflandre, 1959

Zygrhablithus bijugatus (Deflandre)

Zygolithus bijugatus Deflandre, in Deflandre and Fert, 1954, p. 148, pl. 11 , figs. 20,21 ; text-fig. 59 .

Zygrhablithus bijugatus (Deflandre) Deflandre, 1959, p. 135.

\section{ACKNOWLEDGMENTS}

We are grateful to many of the scientific staff on board the Glomar Challenger. Thanks are also due to Dr. Stefan Gartner, Department of Oceanography, Texas A\&M University, Dr. M.-P. Aubry, Woods Hole Oceanographic Institution, and Dr. Ellen Thomas, Lamont-Doherty Geological Observatory, for their constructive reviews of this chapter. Deep appreciation is expressed to Drs. Naomoto Komatsu and Yoshihiko Fujita, Teikoku Oil Co., Ltd., for their help and encouragement. We are especially grateful to Miss Reiko Takamatsu, College of Liberal Arts, Kanazawa University, for slide preparation and bookkeeping of samples. Last, but not least, thanks to Mr. Koji Kameo, Faculty of Science, Kanazawa University, for assistance in table preparation.

\section{REFERENCES}

Backman, J., 1979. Pliocene biostratigraphy of DSDP Sites 111 and 116 from the North Atlantic Ocean and the age of northern hemisphere glaciation. Stockholm Contrib. Geol., 32:115-137. 1980. Miocene-Pliocene nannofossils and sedimentation rates in the Hatton-Rockall Basin, NE Atlantic Ocean. Stockholm Contrib. Geol., 36:1-91.

Backman, J., and Shackleton, N. J., 1983. Quantitative biochronology of Pliocene and early Pleistocene calcareous nannofossils from the Atlantic, Indian, and Pacific oceans. Mar. Micropaleontol., 8: 141-170.

Berggren, W. A., Hamilton, N., Johnson, D. A., Pujol, C., Weiss, W., Cepek, P., and Gombos, A. M., Jr., 1983. Magnetobiostratigraphy of Deep Sea Drilling Project Leg 72, Sites 515-518, Rio Grande Rise (South Atlantic). In Barker, P. F., Carlson, R. L., et al., Init. Repts. DSDP, 72: Washington (U.S. Govt. Printing Office), 939-948.

Berggren, W. A., Kent, D. V., and Van Couvering, in press. Neogene geochronology and chronostratigraphy. In Snelling, N. J. (Ed.), Geochronology and the Geologic Time Scale. Geol. Soc. London Mem.

Bukry, D., 1973. Low-latitude coccolith biostratigraphic zonation. In Edgar, N. T., Saunders, J. B., et al., Init. Repts. DSDP, 15: Washington (U.S. Govt. Printing Office), 685-703.

, 1975. Coccolith and silicoflagellate stratigraphy, Northwestern Pacific Ocean, Deep Sea Drilling Project Leg 32. In Larson, R. L., Moberly, R., et al., Init. Repts. DSDP, 32: Washington (U.S. Govt. Printing Office), 677-701.

Farinacci, A. (Ed.), 1976-1983. Catalogue of Calcareous Nannofossils (Vols. 1-11): Rome (Technoprint).

Gartner, S., 1973. Absolute chronology of the late Neogene calcareous nannofossil succession in the equatorial Pacific. Geol. Soc. Am. Bull., 84:2021-2034.

, 1977. Calcareous nannofossil biostratigraphy and revised zonation of the Pleistocene. Mar. Micropaleontol., 2:1-25.

Haq, B. U., and Takayama, T., 1984. Neogene calcareous nannoplankton datum planes and their calibration to magnetostratigraphy. In Ikebe, N., and Tsuchi, R. (Eds.), Pacific Neogene Datum Planes: Tokyo (University of Tokyo Press), pp. 27-33.

Haq, B. U., Worsley, T. R., Burckle, L. H., Douglas, R. G., Keigwin, L.D ., Jr., Opdyke, N. D., Savin, S. M., Sommer, M. A., II, Vincent, E., and Woodruff, F., 1980. The late Miocene marine carbon-isotopic shift and the synchroneity of some phytoplanktonic biostratigraphic events. Geology, 8:427-431.

Loeblich, A. R., Jr., and Tappan, H., 1966. Annotated index and bibliography of the calcareous nannoplankton. Phycologia, 5:81-216. 1968. Annotated index and bibliography of the calcareous nannoplankton II. J. Paleontol., 42:584-598. 
1969. Annotated index and bibliography of the calcareous nannoplankton III. J. Paleontol., 43:568-588.

1970a. Annotated index and bibliography of the calcareous nannoplankton IV. J. Paleontol., 44:558-574.

1970b. Annotated index and bibliography of the calcareous nannoplankton V. Phycologia, 9:157-174.

, 1971. Annotated index and bibliography of the calcareous nannoplankton VI. Phycologia, 10:315-339.

1973. Annotated index and bibliography of the calcareous nannoplankton VII. J. Paleontol., 47:715-759.

Martini, E., 1971. Standard Tertiary and Quaternary calcareous nannoplankton zonation. In Farinacci, A. (Ed.), Plank. Conf., Roma, 1970 Proc. (Vol. 2): Rome (Tecnoscienza), 738-785.

Mazzei, R., Raffi, I., Rio, D., Hamilton, N., and Cita, M. B., 1979. Calibration of late Neogene calcareous plankton datum planes with the paleomagnetic record of Site 397 and correlation with Moroccan and Mediterranean sections. In von Rad, U., Ryan, W. B. F., et al., Init. Repts. DSDP , 47, Pt. 1: Washington (U.S. Govt. Printing Office), 375-389.

Niitsuma, N., 1982. Paleomagnetic results, Middle America Trench off Mexico, Deep Sea Drilling Project Leg 66. In Watkins, J. S., Moore, J. C., et al., Init. Repts. DSDP, 66: Washington (U.S. Govt. Printing Office), 737-768.

Okada, H., and Bukry, D., 1980. Supplementary modification and introduction of code numbers to the low-latitude coccolith biostratigraphic zonation (Bukry, 1973; 1975). Mar. Micropaleontol., 5:321325 .
Poore, R. Z., Tauxe, L., Percival, S. F., Jr., LaBrecque, J. L., Wright, R., Peterson, N. P., Smith, C. C., Tucker, P., and Hsü, K. J., 1984. Late Cretaceous-Cenozoic magnetostratigraphic and biostratigraphic correlations for the South Atlantic Ocean, Deep Sea Drilling Project Leg 73. In Hsü, K. J., LaBrecque, J. L., et al., Init. Repts. $D S D P, 73$ : Washington (U.S. Govt. Printing Office), 645-655.

Ryan, W. B. F., Cita, M. B., Dreyfus Rawson, M., Burckle, L. H., and Saito, T., 1974. A paleomagnetic assignment of Neogene stage boundaries and the development of isochronous datum planes between the Mediterranean, the Pacific, and the Indian Ocean in order to investigate the response of the World Ocean to the Mediterranean "Salinity Crisis." Ital. Paleont. Riv., 80:631-688.

Steinmetz, J. C., 1979. Calcareous nannofossils from the North Atlantic Ocean, Leg 49, Deep Sea Drilling Project. In Luyendyk, B. P., Cann, J. R., et al., Init. Repts. DSDP, 49: Washington (U.S. Govt. Printing Office), 519-531.

Stradner, H., and Allram, F., 1982. The nannofossil assemblage of Deep Sea Drilling Project Leg 66, Middle America Trench. In Watkins, J. S., Moore, J. C., et al., Init. Repts. DSDP, 66: Washington (U.S. Govt. Printing Office), 589-639.

Stradner, H., and Papp, A., 1961. Tertiäre Discoasteriden aus Österreich und deren stratigraphischen Bedeutung mit Hinweisen auf Mexico, Rumänien und Italien. Jahrb. Geol. Bundesansts. Sonderband, 7:1-159.

Date of Initial Receipt: 25 April 1985

Date of Acceptance: 5 December 1985 


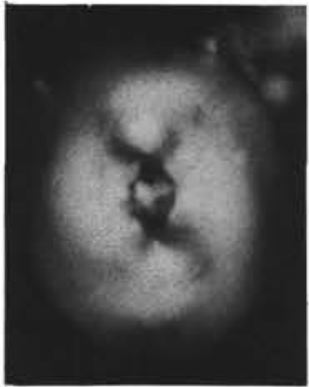

$1 \mathrm{a}$

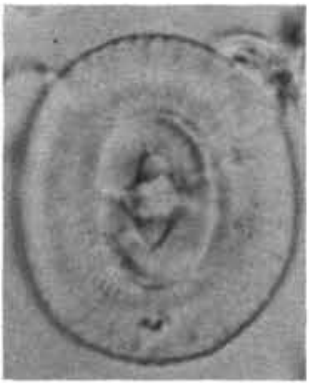

$1 b$

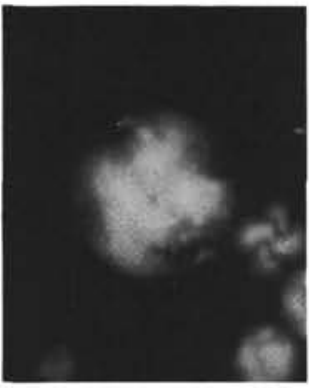

$6 a$

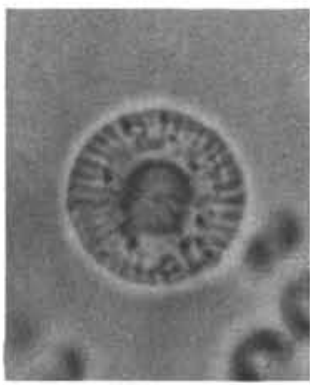

$6 b$

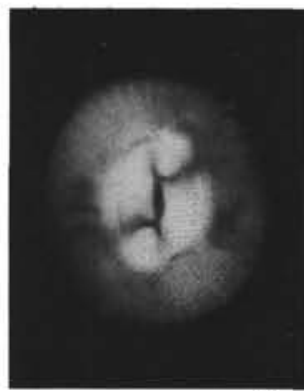

$2 a$

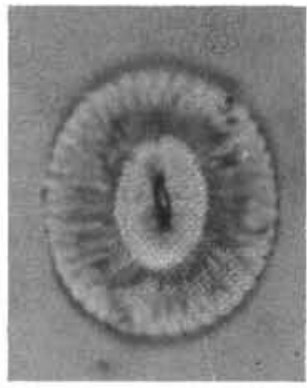

$2 b$

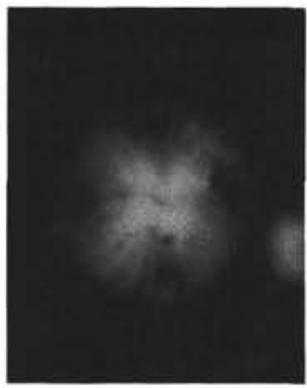

$7 a$

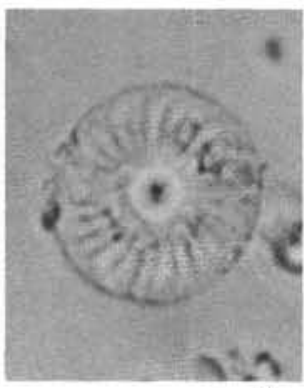

$7 b$

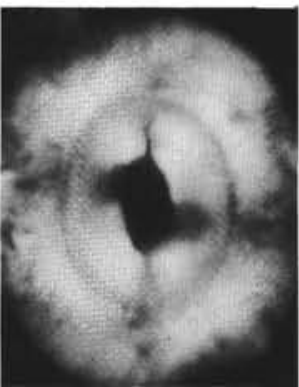

$3 a$

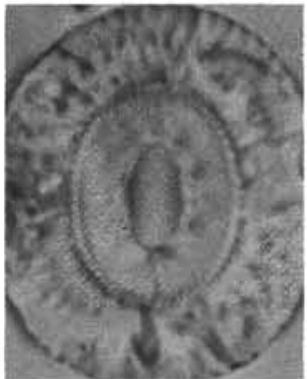

$3 b$

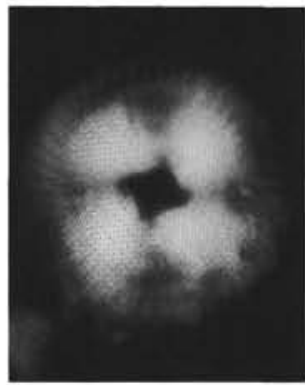

$8 a$

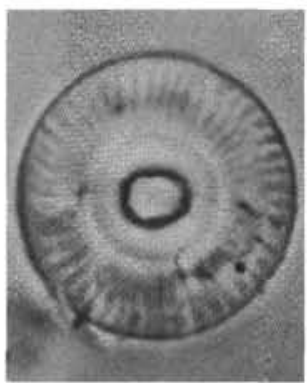

$8 b$
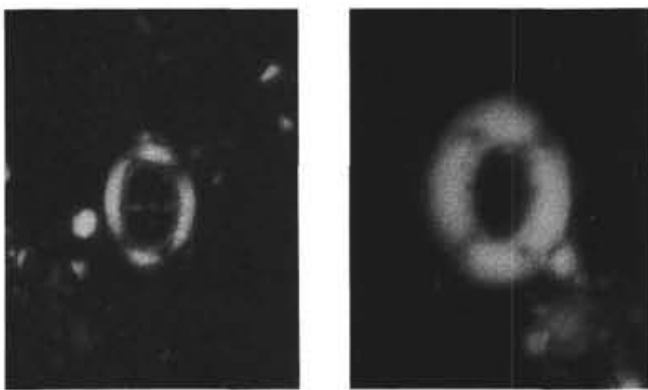

$5 a$

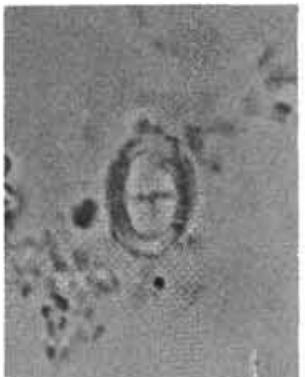

$4 b$

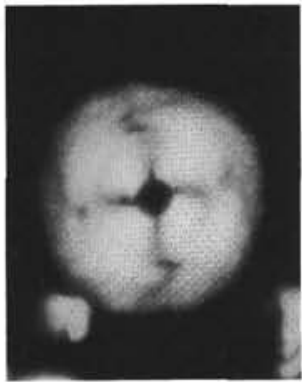

$9 a$

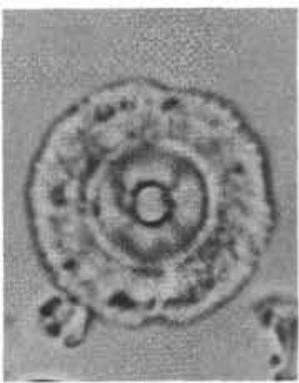

$9 b$

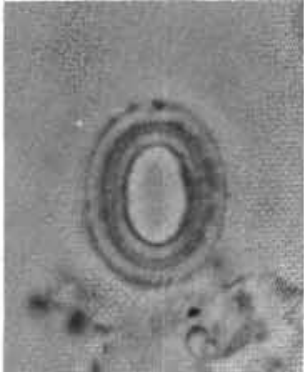

$5 b$

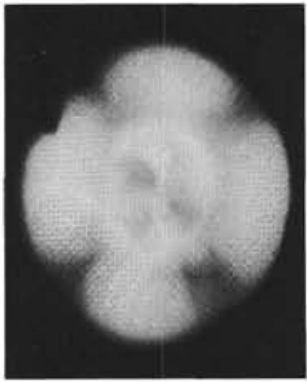

$10 a$

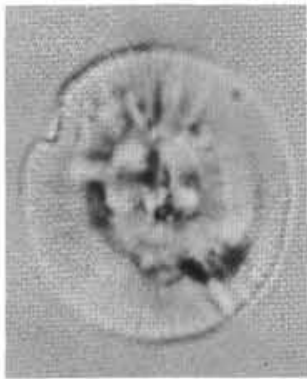

$10 \mathrm{~b}$

$$
10 \mu \mathrm{m}
$$

Plate 1. (All figures are same magnification; $\mathrm{a}=$ crossed nicols, $\mathrm{b}=$ without nicols.) 1. Coccolithus crassipons Bouché, Sample 606-2,CC. 2. Coccolithus miopelagicus Bukry, Sample 608-28-6, 46-47 cm. 3. Coccolithus eopelagicus (Bramlette and Riedel) Bramlette and Sullivan, Sample 608-49-2, $85 \mathrm{~cm}$. 4. Coccolithus streckerii Takayama and Sato, n. sp., Holotype, TOCCN 3538(1), Sample 608-5-5, 46-47 cm. 5. Coccolithus sp., Sample 611-10-4, 50-51 cm. 6, 7. Calcidiscus leptoporus (Murray and Blackman) Loeblich and Tappan, (6) Sample 606-2,CC; (7) Sample 607-7-4, 47-48 cm. 8. Calcidiscus macintyrei (Bukry and Bramlette) Loeblich and Tappan, Sample 606-6,CC. 9. Calcidiscus formosus (Kamptner) Loeblich and Tappan, Sample 608-50-2, 46-47 cm. 10. Dictyococcites bisectus (Hay, Mohler, and Wade) Bukry and Percival, Sample $608-46, C C$. 

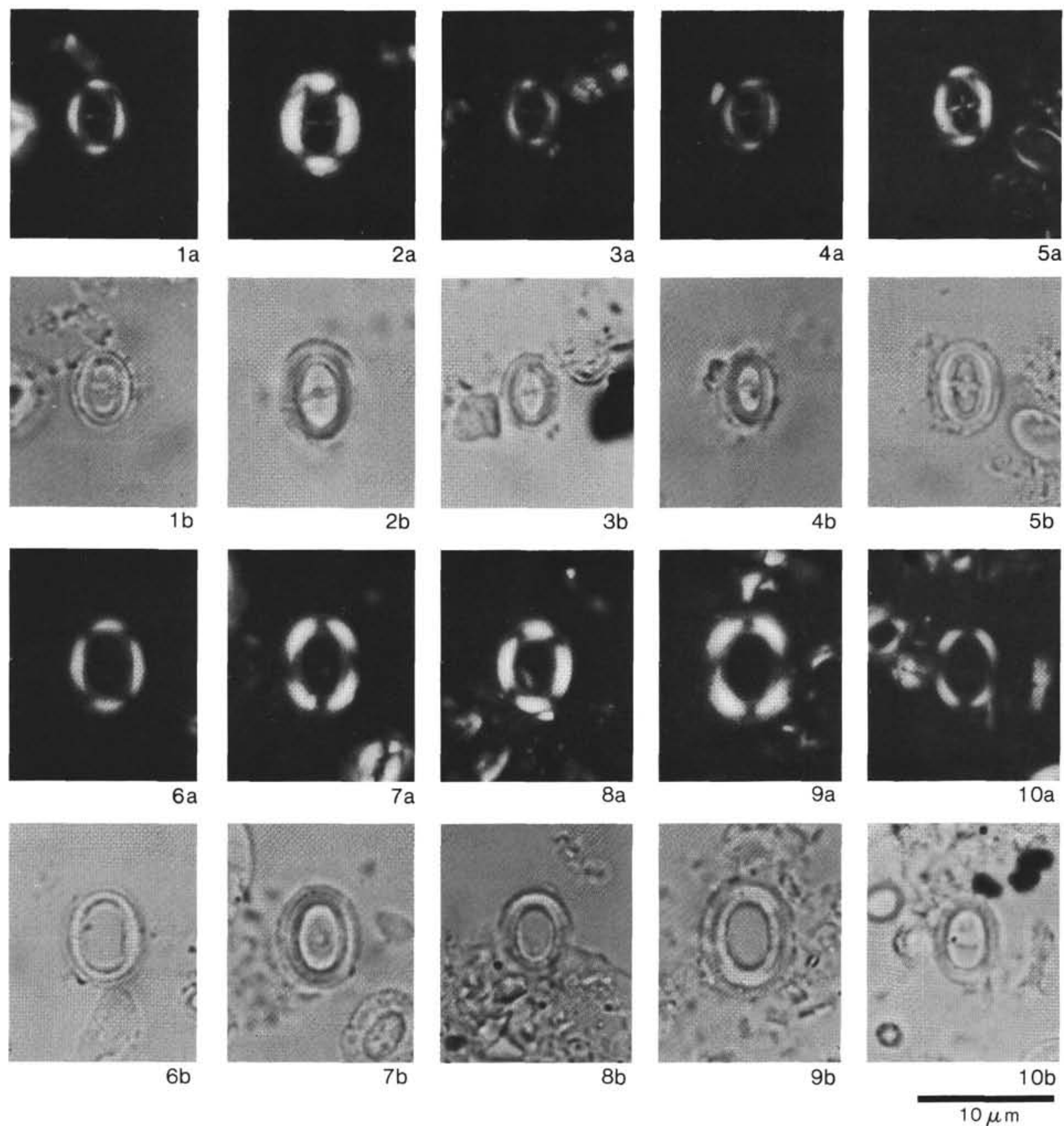

Plate 2. (All figures are same magnification; $\mathrm{a}=$ crossed nicols, $\mathrm{b}=$ without nicols.) 1-10. Coccolithus streckerii Takayama and Sato, $\mathrm{n}$. sp., Paratypes, TOCCN $3538(2)$ to $3538(11)$, Sample $608-5-5,46-47 \mathrm{~cm}$. 


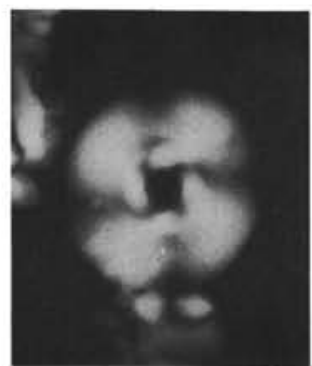

$1 \mathrm{a}$

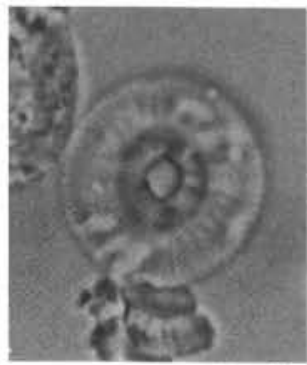

$1 b$

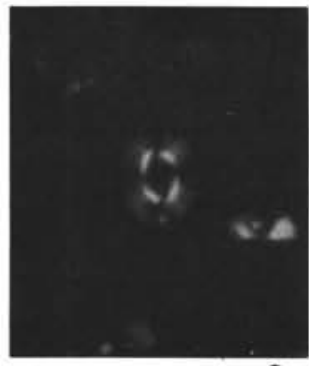

$6 a$

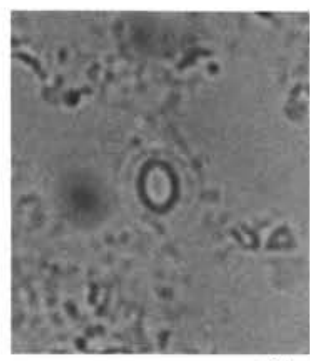

$6 b$

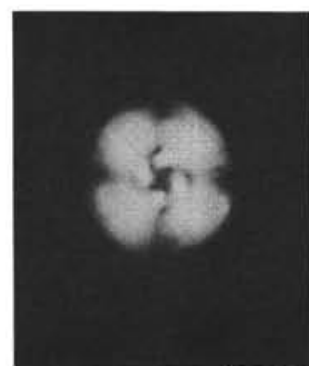

$2 a$

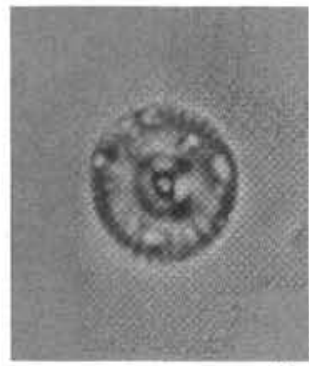

$2 b$

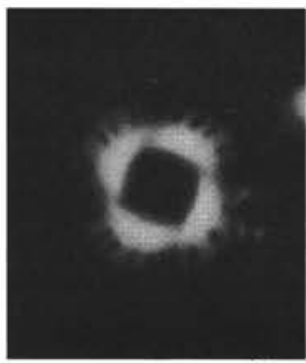

$7 a$

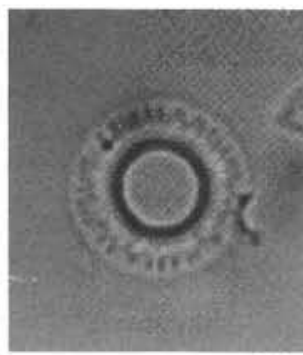

$7 b$

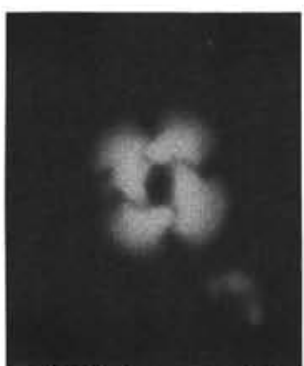

3a

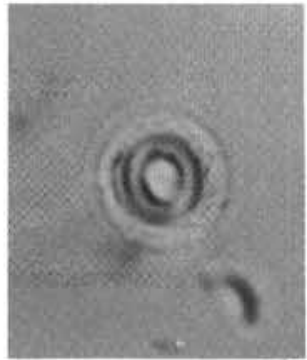

$3 b$

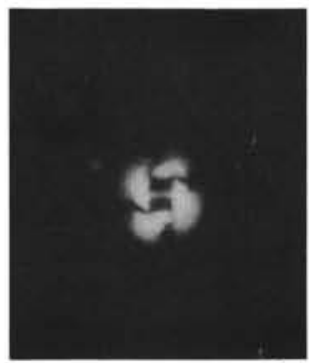

$8 \mathrm{a}$

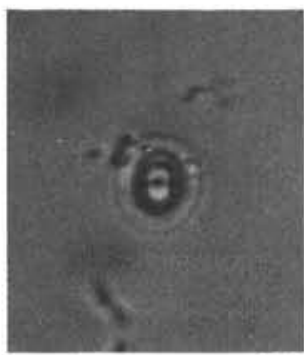

$8 b$

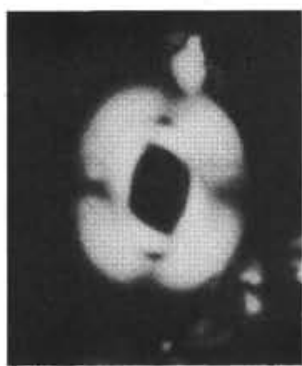

$4 a$

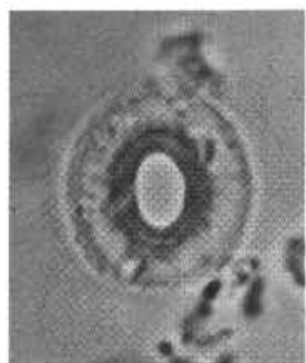

$4 b$

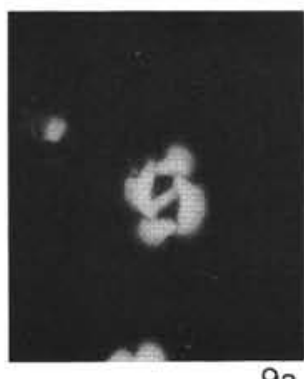

$9 a$

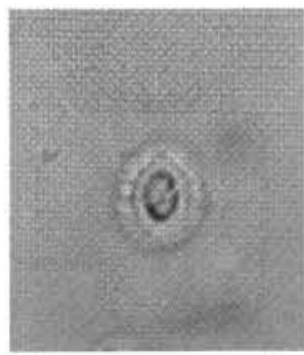

$9 b$

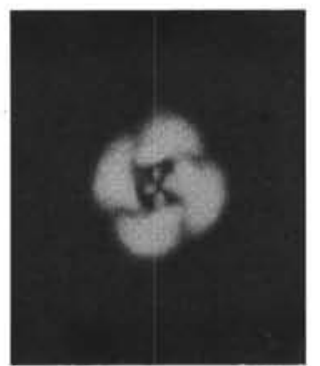

$5 a$

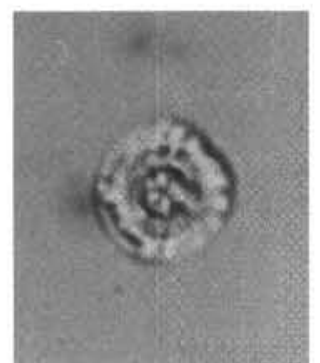

$5 b$
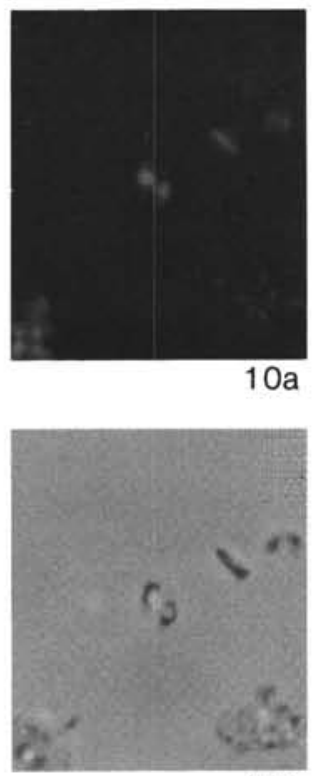

$10 b$

$10 \mu \mathrm{m}$

Plate 3. (All figures are same magnification; $\mathrm{a}=$ crossed nicols, $\mathrm{b}=$ without nicols.) 1. Cyclicargolithus abisectus (Müller) Bukry, Sample $608-49-2,85 \mathrm{~cm}$. 2. Cyclicargolithus floridanus (Roth and Hay) Bukry, Sample 608-33-2, $46-47 \mathrm{~cm}$. 3. Reticulofenestra sp. A, Sample 607A-5,CC. 4. Reticulofenestra pseudoumbilica (Gartner) Gartner, Sample 608-28-2, 46-47 cm. 5. Reticulofenestra reticulata (Gartner and Smith) Roth, Sample 608-52,CC. 6. Emiliania huxleyi (Lohmann) Hay and Mohler, Sample 607-1-2, 47-48 cm. 7. Pseudoemiliania lacunosa (Kamptner) Gartner, Sample 606A-2,CC. 8. Gephyrocapsa parallela Hay and Beaudry, Sample 606-3-4, 47-48 cm. 9. Gephyrocapsa oceanica Kamptner, Sample 606-2-6, 47-48 cm. 10. Gephyrocapsa sinuosa Hay and Beaudry, Sample 607-7-4, 47-48 cm. 


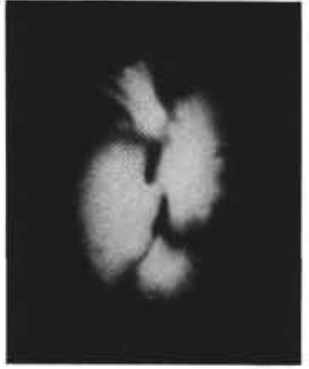

$1 \mathrm{a}$

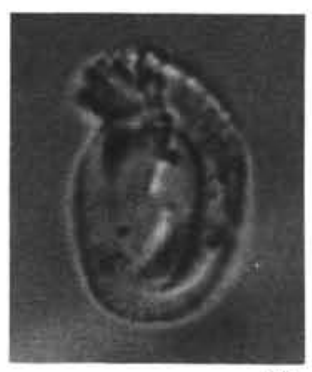

$1 b$

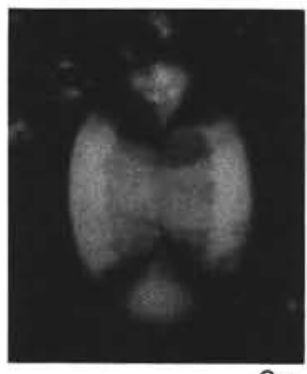

$6 a$

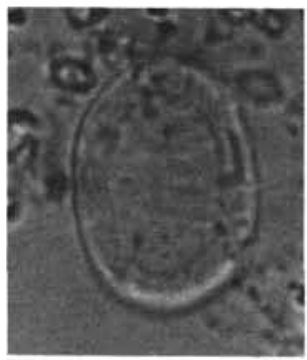

$6 b$

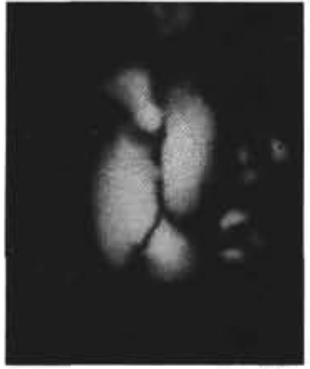

$2 a$

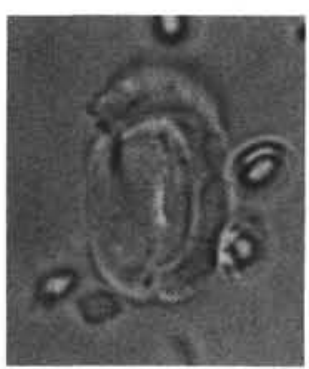

$2 b$

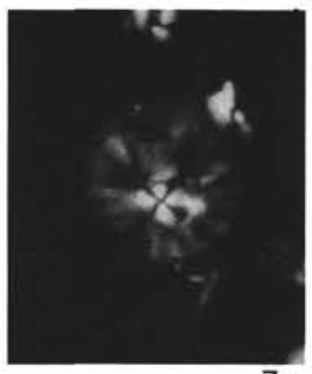

$7 a$

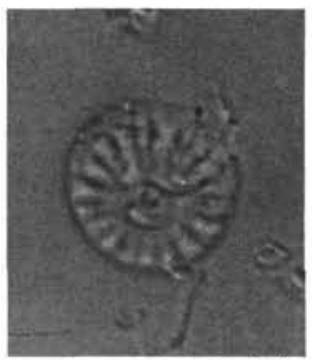

$7 \mathrm{~b}$

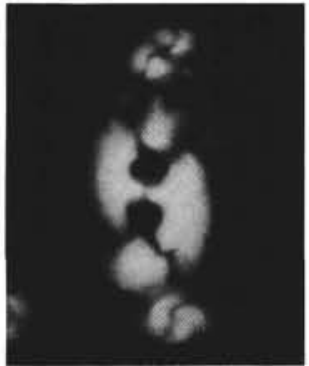

$3 a$

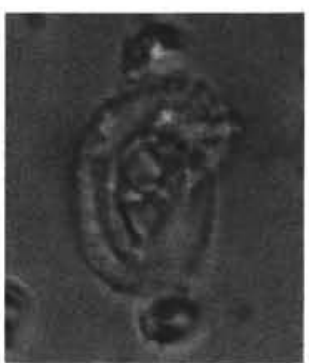

$3 b$

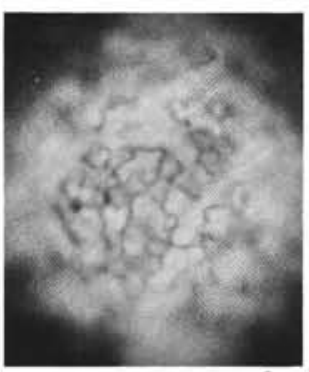

$8 a$

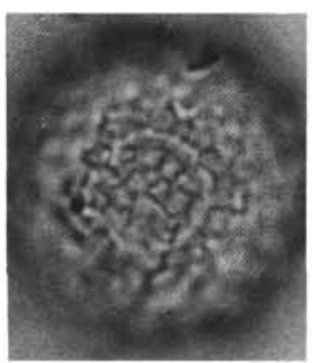

$8 b$
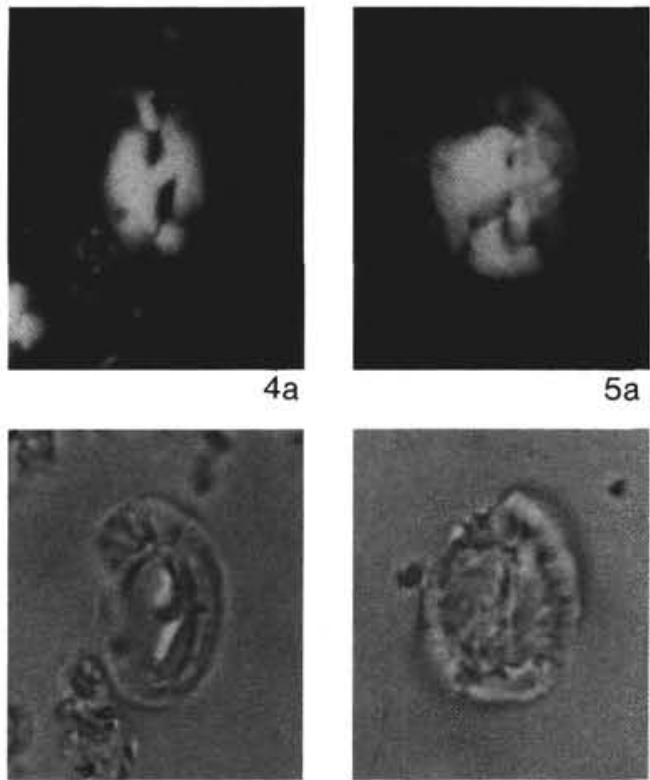

$4 b$

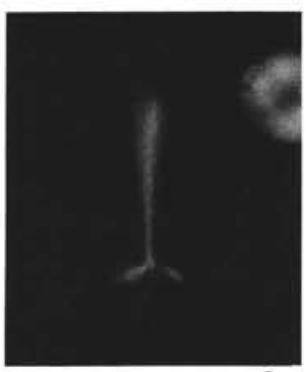

$9 a$

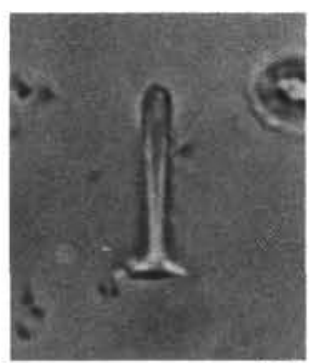

$9 b$

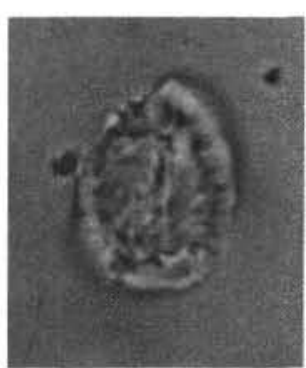

$5 b$

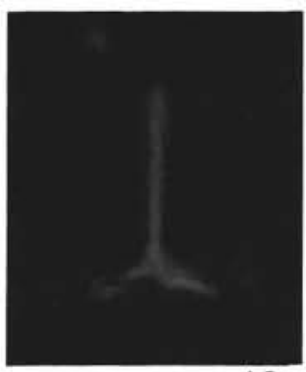

$10 a$

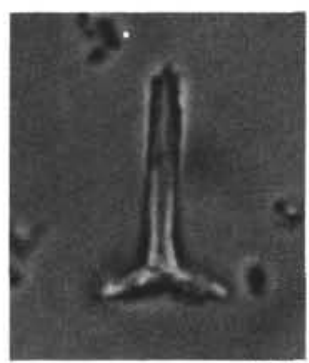

$10 b$

$10 \mu \mathrm{m}$

Plate 4. (All figures are same magnification; $\mathrm{a}=$ crossed nicols, $\mathrm{b}=$ without nicols.) 1. Helicosphaera wallichi (Lohmann) Okada and McIntyre, Sample 606-5-1, 47-48 cm. 2. Helicosphaera carteri (Wallich) Kamptner, Sample 606-2-6, 47-48 cm. 3. Helicosphaera inversa (Gartner) Haq, Sample 607-2-4, 47-48 cm. 4. Helicosphaera sellii (Bukry and Bramlette) Jafar and Martini, Sample 607-10-1, 47-48 cm. 5. Helicosphaera perch-nielseniae (Haq) Jafar and Martini, Sample 608-49-2, 46-47 cm. 6. Discolithina japonica Takayama, Sample 607-4-4, 47-48 cm. 7. Oolithotus antillarum (Cohen) Reinhardt, Sample 606-9-4, 47-48 cm. 8. Thoracosphaera heimi (Lohmann) Kamptner, Sample 606-9-4, 47-48 cm. 9. Rhabdosphaera clavigera Murray and Blackman, Sample 606-5-1, 47-48 cm. 10. Rhabdosphaera stylifera Lohmann, Sample $606-5-1,47-48 \mathrm{~cm}$. 


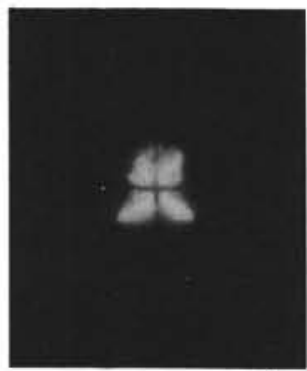

$1 \mathrm{a}$

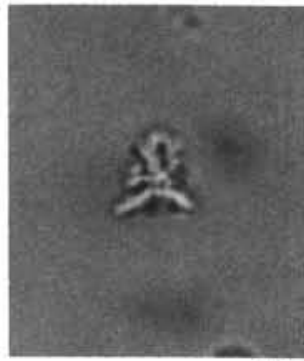

$1 b$

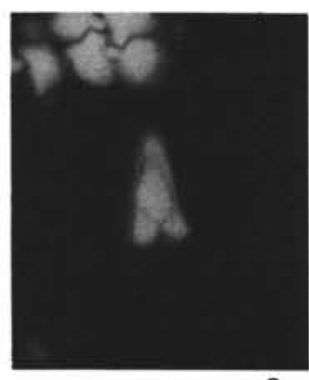

$6 a$

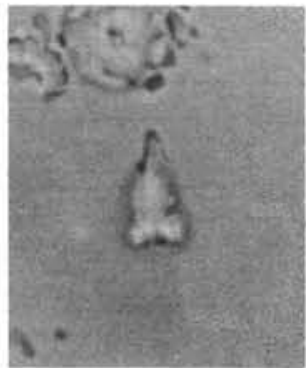

$6 b$

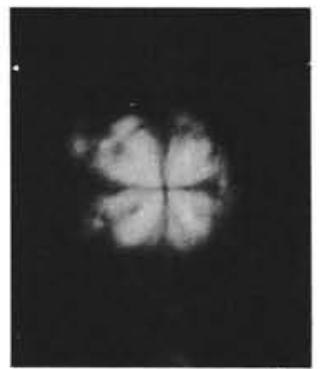

$2 a$

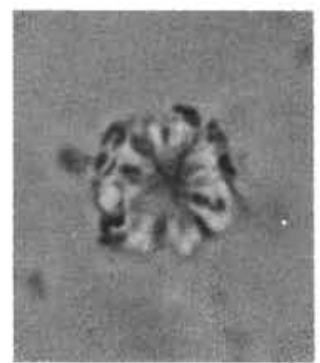

$2 b$
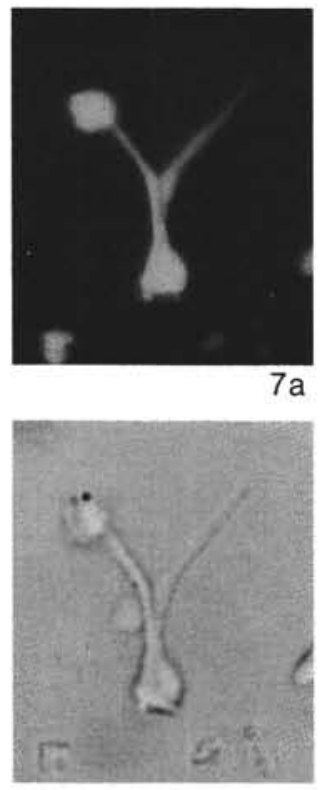

$7 b$

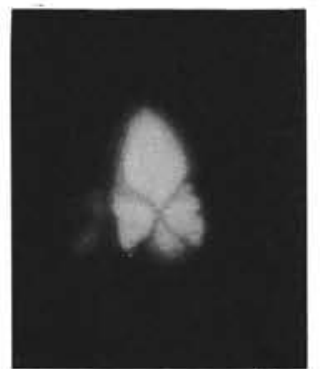

$3 a$

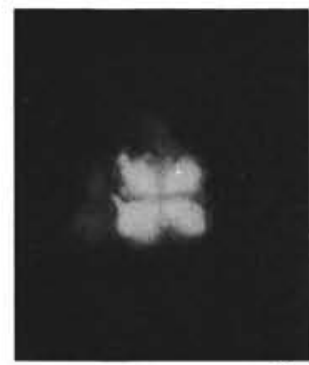

$3 b$

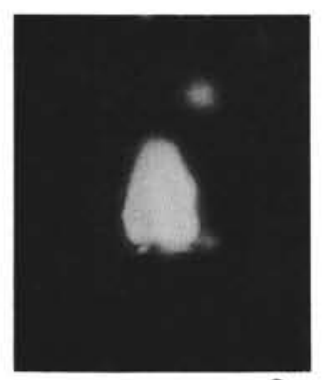

$8 a$

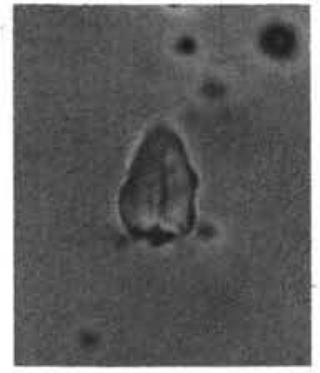

$8 b$

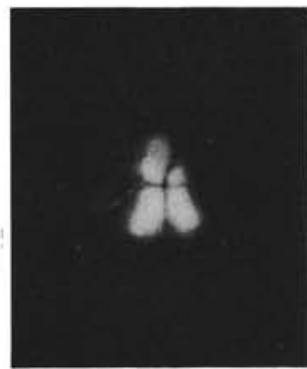

$4 a$

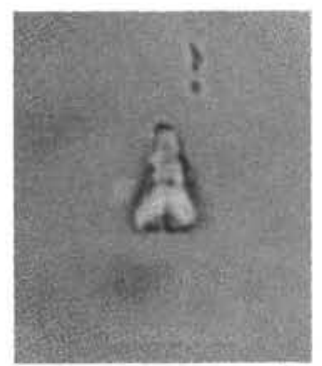

$4 b$

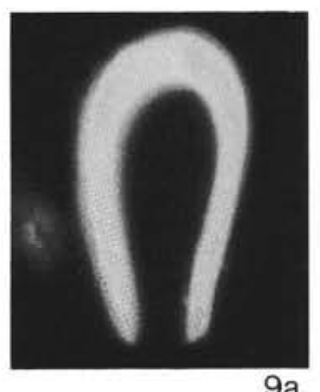

$9 a$

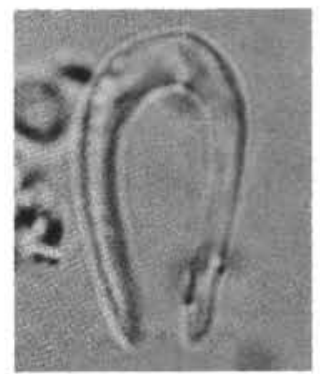

$9 b$

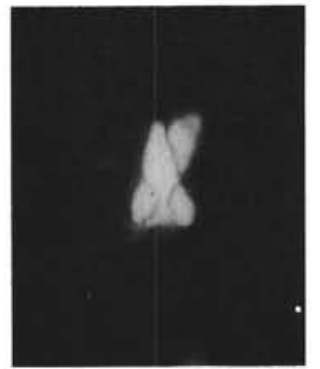

$5 a$

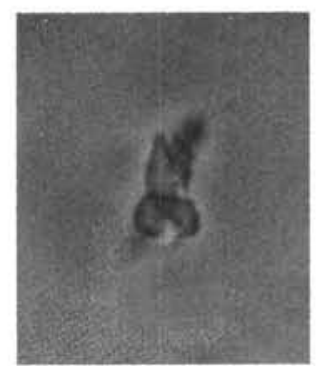

$5 b$
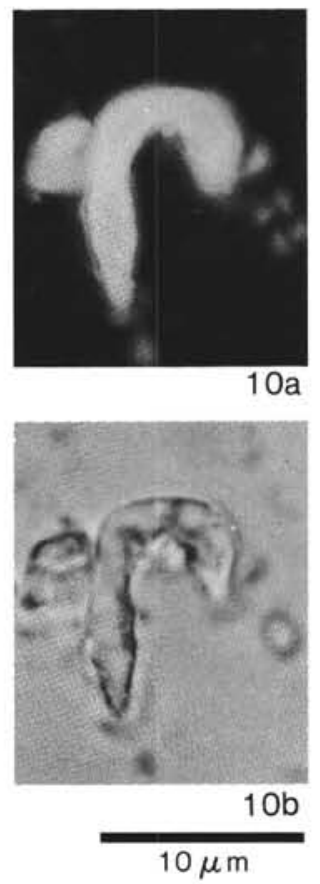

Plate 5. (All figures are same magnification. In Figs. 1, 2, and 4-10, $\mathrm{a}=$ crossed nicols, $\mathrm{b}=$ without nicols; in Fig. 3 , $\mathrm{a}=$ long axis $45^{\circ}$ to crossed nicols; $\mathrm{b}=$ long axis $0^{\circ}$ to crossed nicols.) 1. Sphenolithus abies Deflandre, Sample 606-16-2, 47-48 cm. 2. Sphenolithus moriformis (Brönniman and Stradner) Bramlette and Wilcoxon, Sample 607-20-2, 47-48 cm. 3. Sphenolithus heteromorphus Deflandre, Sample 608-33-2, 46-47 $\mathrm{cm}$. 4. Sphenolithus belemnos Bramlette and Wilcoxon, Sample 608-39-3, 46-47 cm. 5. Sphenolithus ciperoensis Bramlette and Wilcoxon, Sample 608-49-2, 46-47 cm. 6. Sphenolithus distentus (Martini) Bramlette and Wilcoxon, Sample 608-49-2, 46-47 cm. 7, 8. Sphenolithus predistentus Bramlette and Wilcoxon, (7) Sample 608-49-2, 46-47 cm; (8) Sample 608-49-4, 46-47 cm. 9. Ceratolithus telesmus Norris, Sample $606-1$, CC. 10. Ceratolithus rugosus Bukry and Bramlette, $607-15-4,47-48 \mathrm{~cm}$. 


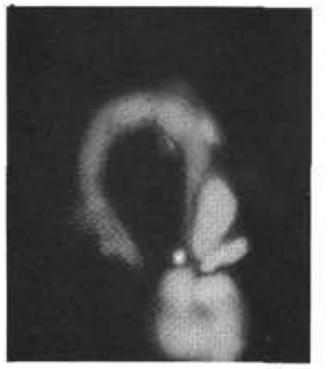

$1 \mathrm{a}$

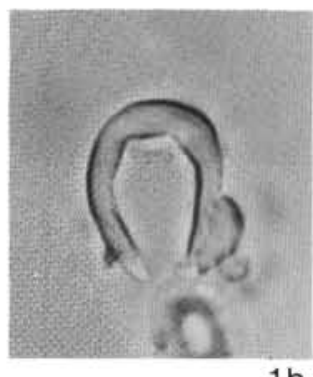

$1 \mathrm{~b}$

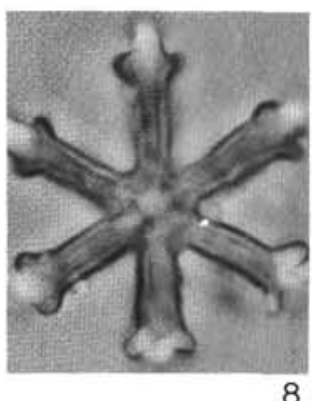

8

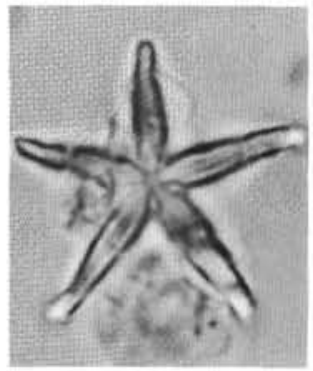

13

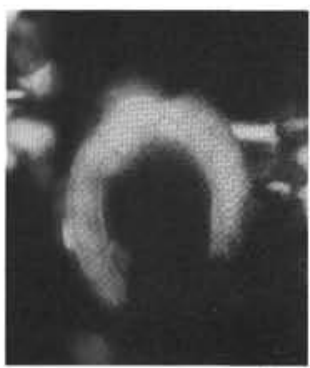

$2 a$

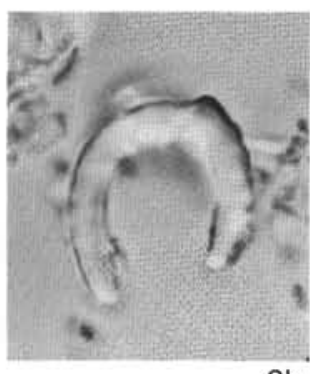

$2 b$
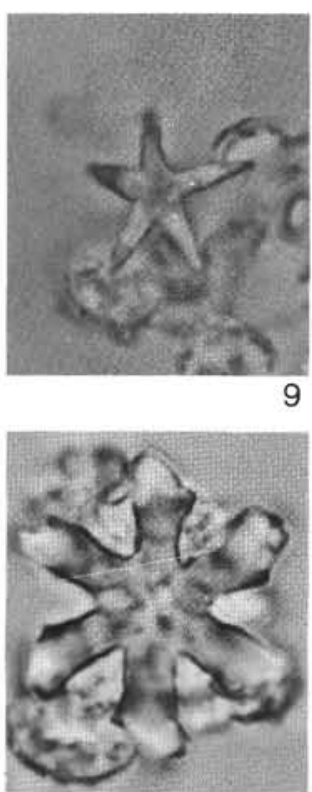

14

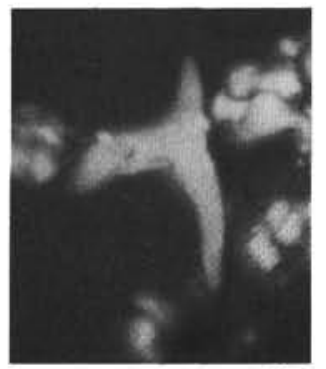

$3 a$

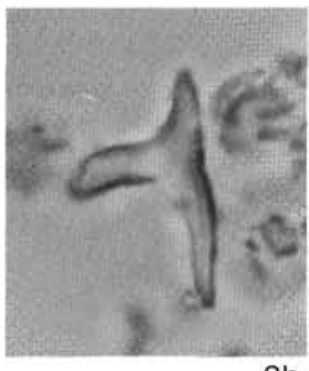

$3 b$

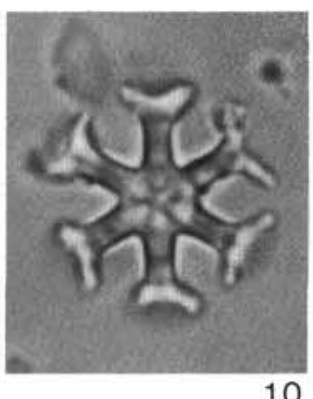

10

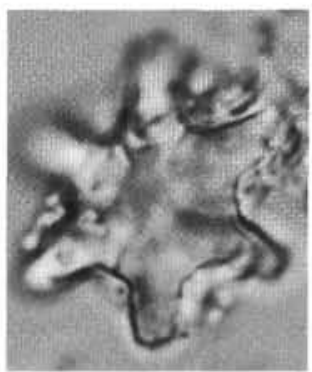

15

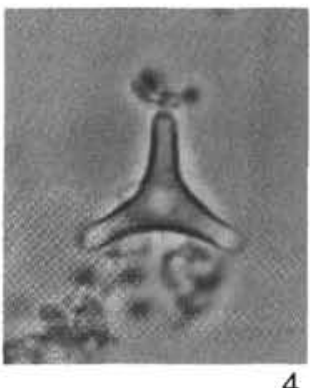

4

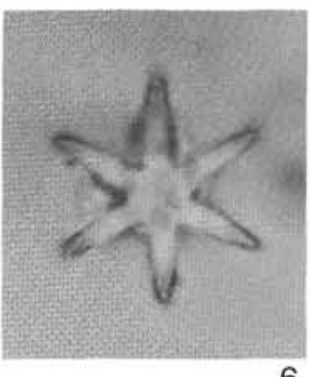

6

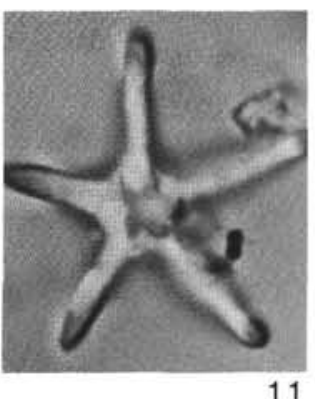

11

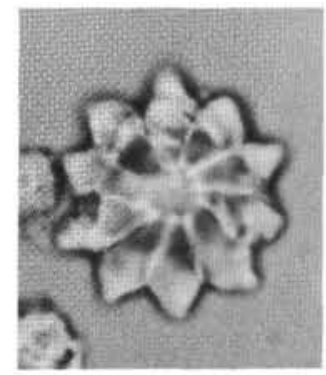

16
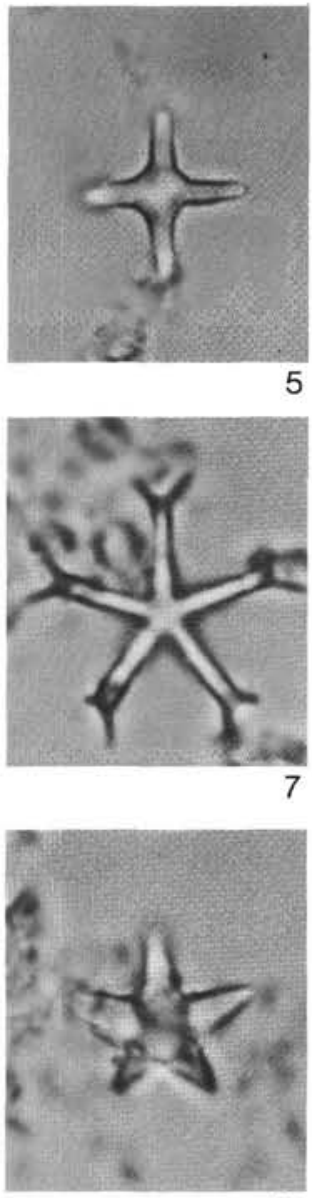

12

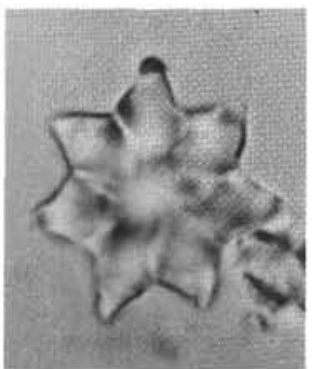

17

Plate 6. (All figures are same magnification. In Figs. 1-3, a $=$ crossed nicols, b = without nicols; Figs. 4-17, without nicols.) 1. Amaurolithus delicatus Gartner and Bukry, Sample 607-23-4, 47-48 cm. 2. Amaurolithus primus (Bukry and Percival) Gartner and Bukry, Sample 607-25,CC. 3. Amaurolithus tricorniculatus (Gartner) Gartner and Bukry, Sample 607-23,CC. 4. Discoaster triradiatus Tan Sin Hok, Sample 606-7,CC. 5. Discoaster tamalis Kamptner, Sample 607-15-2, 47-48 cm. 6. Discoaster brouweri Tan Sin Hok, Sample 606-11, CC. 7. Discoaster pentaradiatus Tan Sin Hok, Sample 606A-15,CC. 8. Discoaster surculus Martini and Bramlette, Sample 607-22-4, 47-48 cm. 9. Discoaster asymmetricus Gartner, Sample 611C-21,CC. 10. Discoaster variabilis Martini and Bramlette, Sample 611C-39-2, 52-53 cm. 11. Discoaster quinqueramus Gartner, Sample 611C-40-2, 44-45 cm. 12. Discoaster berggrenii Bukry, Sample 607-27,CC. 13. Discoaster hamatus Martini and Bramlette, Sample 608-23-4, 46-47 cm. 14. Discoaster loeblichii Bukry, Sample 608-19,CC. 15. Discoaster kugleri Martini and Bramlette, Sample 607-20-2, 47-48 cm. 16. Discoaster barbadiensis Tan Sin Hok, Sample 608-52,CC. 17. Discoaster saipanensis Bramlette and Riedel, Sample $608-52-2,57-58 \mathrm{~cm}$. 

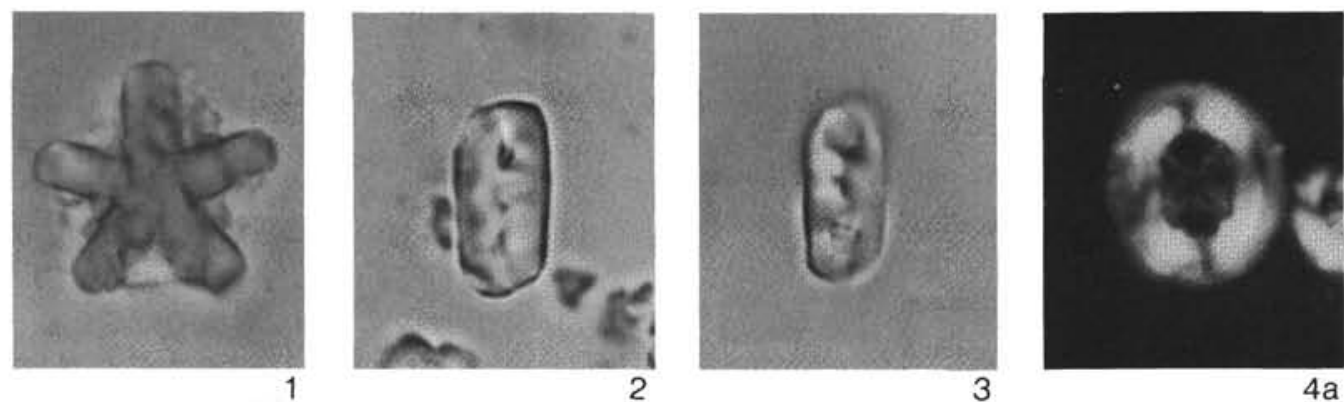

3

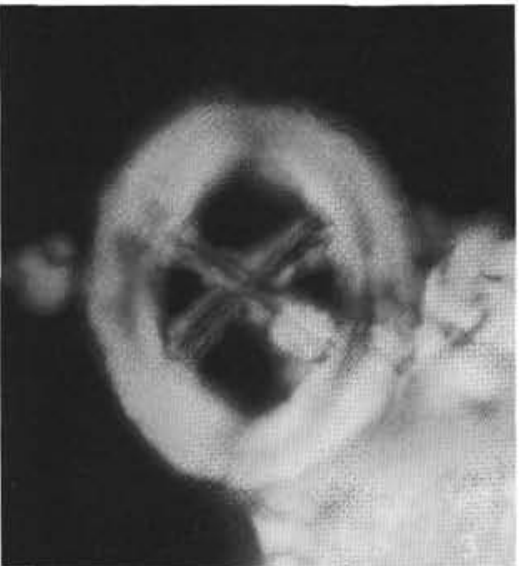

$6 a$

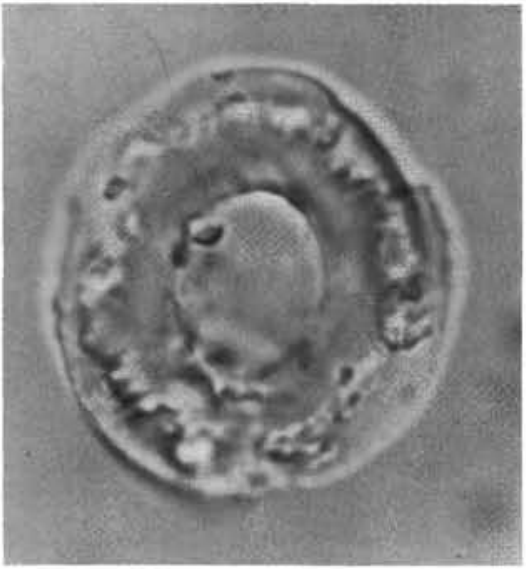

$5 b$

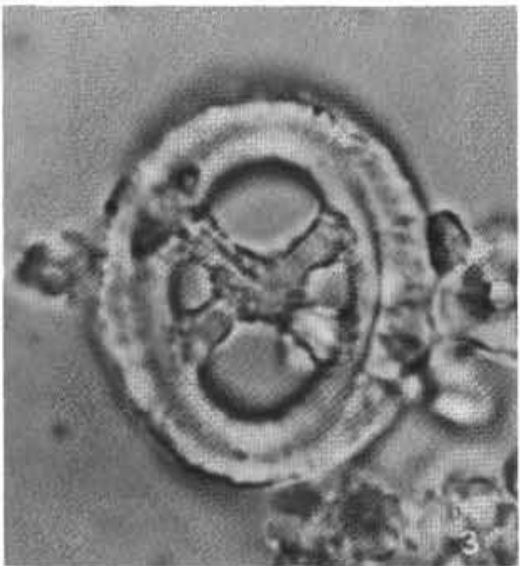

$6 b$
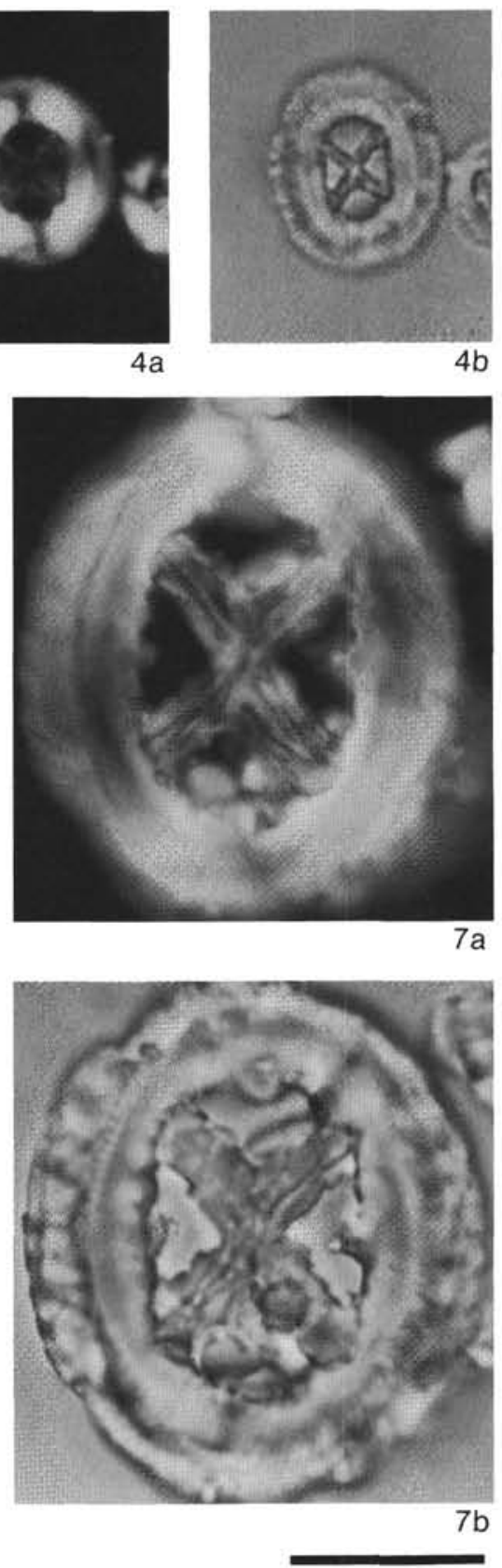

$10 \mu \mathrm{m}$

Plate 7. (All figures are same magnification; in Figs. 4-7, $\mathrm{a}=$ crossed nicols, $\mathrm{b}=$ without nicols; Figs. 1-3, without nicols.) 1. Discoaster tani Bramlette and Riedel, Sample 608-52-2, 57-58 cm. 2, 3. Isthmolithus recurvus Deflandre, (2) Sample 608-52,CC; (3) 608-52-2, 57-58 cm. 4. Chiasmolithus altus Bukry and Percival, Sample 608-49-2, 46-47 cm. 5. Reticulofenestra umbilica (Levin) Martini and Ritzkowski, Sample 608-50-2, 46-47 cm. 6. Chiasmolithus oamaruensis (Deflandre) Hay, Mohler, and Wade, Sample 608-53-2, 63-64 cm. 7. Chiasmolithus grandis (Bramlette and Riedel) Radomski, Sample 608-55,CC. 


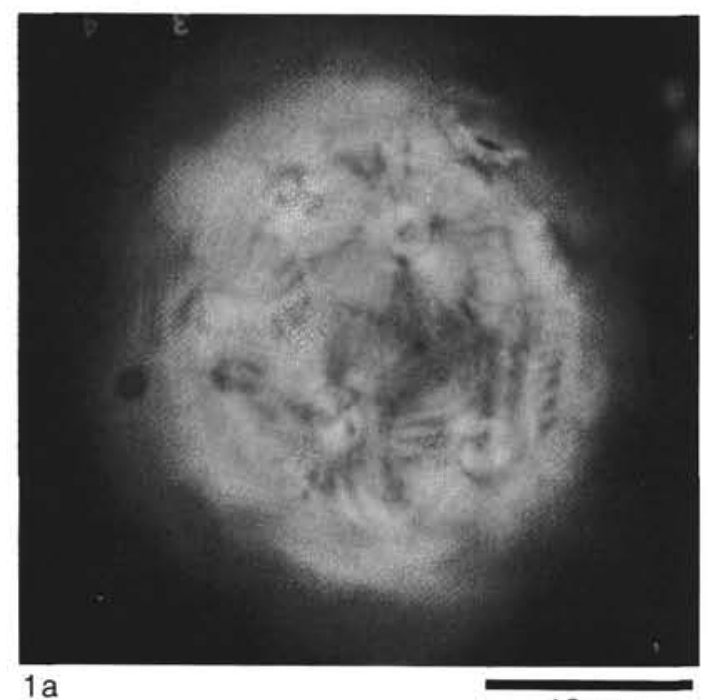

$10 \mu \mathrm{m}$

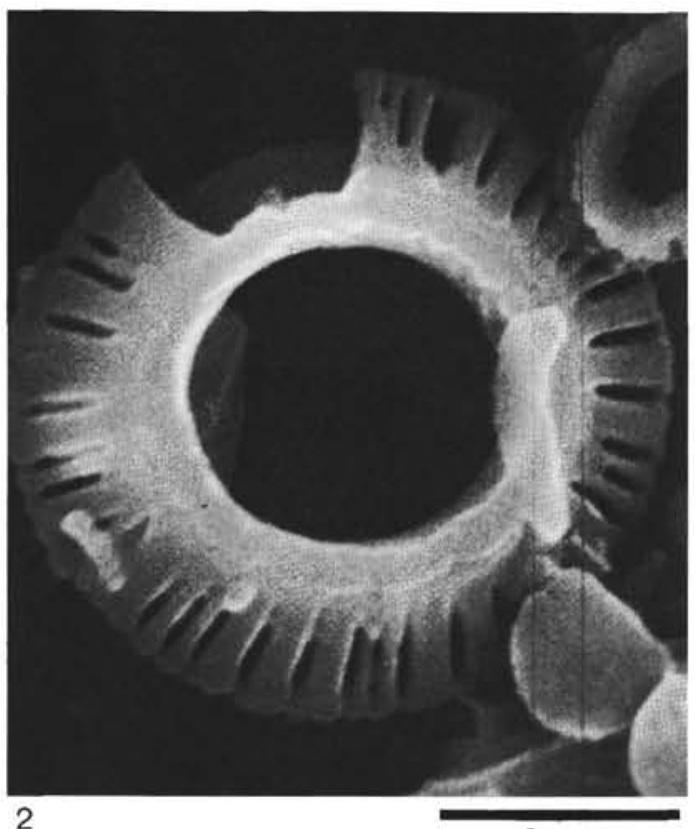

$2 \mu \mathrm{m}$
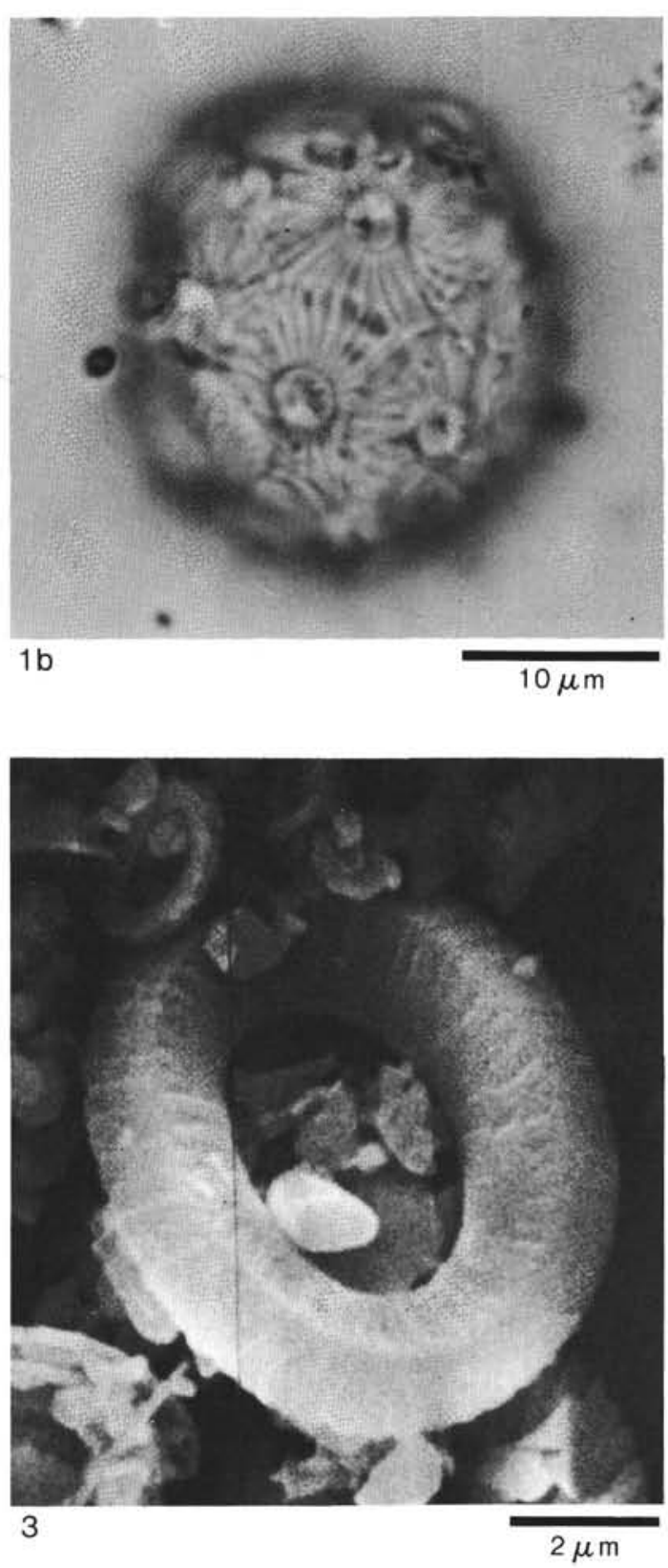

Plate 8. (In Fig. 1, a = crossed nicols, $\mathrm{b}=$ without nicols; Figs. 2 and 3 are SEM photographs.) 1. Calcidiscus leptoporus (Murray and Blackman) Loeblich and Tappan, Sample 606A-3,CC. 2. Pseudoemiliania lacunosa (Kamptner) Gartner, Sample 608-5-5, 46-47 cm. 3. Coccolithus streckerii Takayama and Sato, n. sp., Paratype, TOCCNS 367, Sample 608-5-5, 46-47 cm. 